A EVOLUÇÃO HISTÓRICA DO CONTROLE DISCIPLINAR DA MAGISTRATURA PAULISTA 
JOSÉ ROBERTO LEME ALVES DE OLIVEIRA

\section{A EVOLUÇÃO HISTÓRICA DO CONTROLE DISCIPLINAR DA MAGISTRATURA PAULISTA}

\section{TESE DE DOUTORADO}

ORIENTADOR: Professor Titular IGNÁCIO M. PovedA VELASCO

Faculdade de Direito da Universidade de São Paulo

São Paulo

2014 
Em memória do Professor

Luiz Carlos de Azevedo 


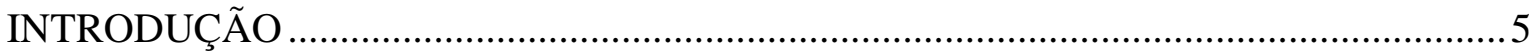

1. O CONTROLE DISCIPLINAR DA MAGISTRATURA NO PERÍODO COLONIAL

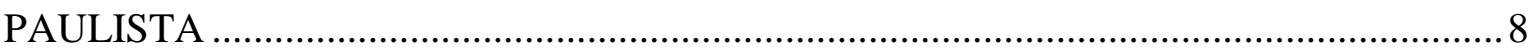

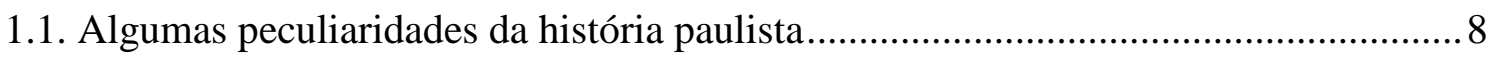

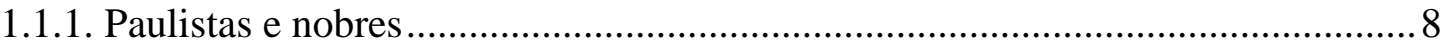

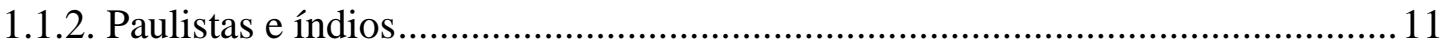

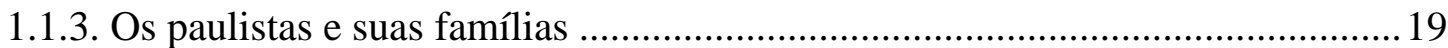

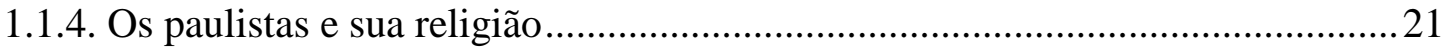

1.1.5. As capitanias hereditárias que deram origem ao território paulista..................22

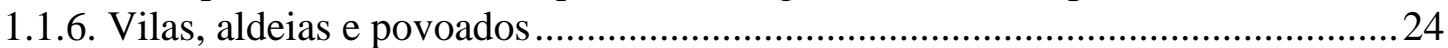

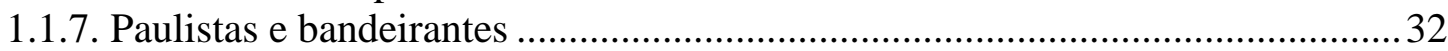

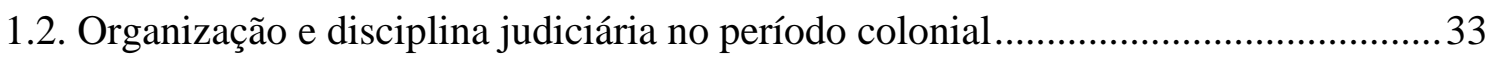

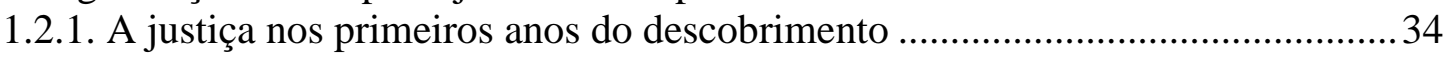

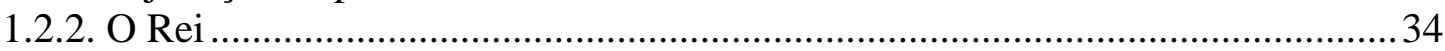

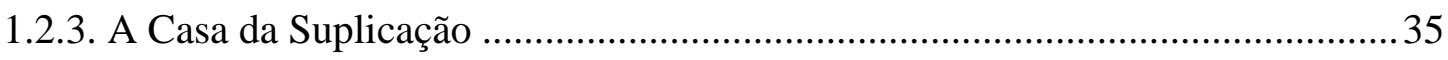

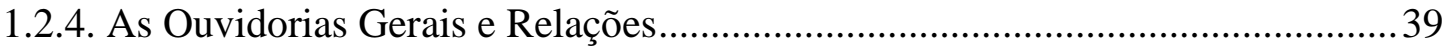

1.2.5. Os Donatários e suas Ouvidorias, a Ouvidoria-Geral do Brasil e a Ouvidoria das

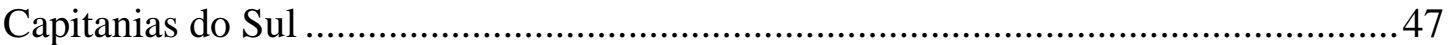

1.2.6. Os Juízes de Fora e os Juízes Ordinários ............................................................ 49

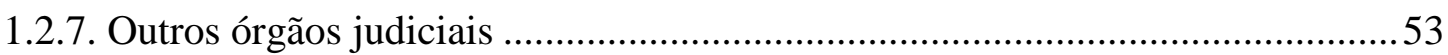

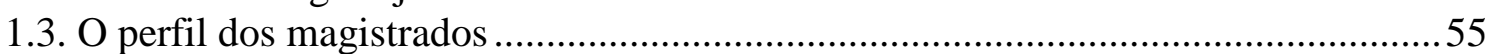

2. O CONTROLE DISCIPLINAR DA MAGISTRATURA PAULISTA APÓS A PROCLAMAÇÃO DA INDEPENDÊNCIA DO BRASIL ................................................57

$2.1 \mathrm{Na}$ Constituição Imperial e na legislação infraconstitucional ..................................57

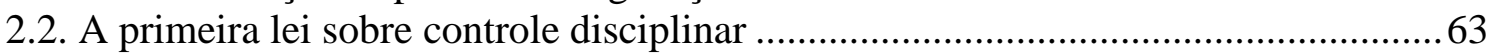

2.3. A instalação do Tribunal da Relação de São Paulo .....................................................64

2.4. Conturbados fatos no tribunal paulista por ocasião da Proclamação da República.. 65

2.5 A Constituição Federal de 1891 e a Constituição do Estado de São Paulo durante a

República Velha.

2.7. Do golpe de Estado de Getúlio Vargas ao Regime Militar........................................ 72

3. O CONTROLE DISCIPLINAR DA MAGISTRATURA PAULISTA EM NOSSOS

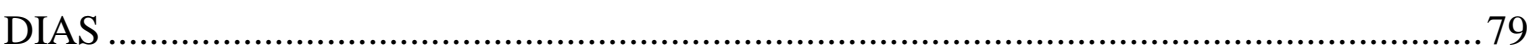

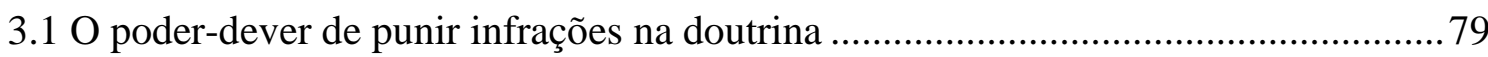

3.2 Os contornos do poder-dever de punir infrações disciplinares na legislação vigente 81

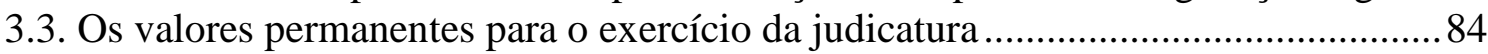

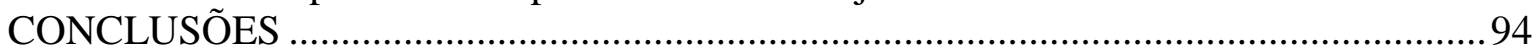

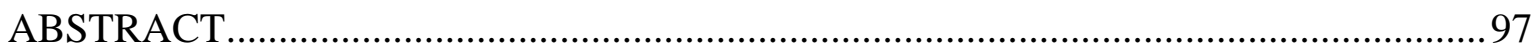

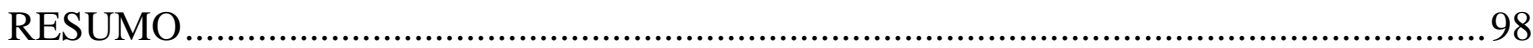

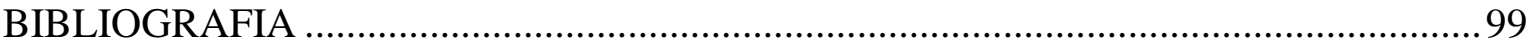




\section{INTRODUÇÃO}

O objetivo deste trabalho é verificar, ao longo da história do Poder Judiciário paulista, de que maneira foi concebida a ideia de dever de comportamento dos juízes e como isso repercutiu, repercute e pode legitimamente continuar a repercutir nos mecanismos de controle disciplinar da magistratura.

Qualquer corporação necessita de regras ou prescrições relativas ao comportamento de seus membros. O conjunto dessas normas é denominado disciplina ${ }^{1}$.

Se a disciplina é violada por algum dos membros do grupo, este tem a faculdade de valer-se de mecanismos de controle disciplinar, tanto para a preservação de sua boa ordem interna quanto para a de sua respeitabilidade externa.

Porém, no âmbito do Poder Público, a punição de infrações de servidores e demais pessoas sujeitas à disciplina dos órgãos e serviços da Administração não é mera faculdade, mas tem a natureza de poder-dever, isto é, ao superior não é lícito tolerar as faltas disciplinares de seus subordinados ${ }^{2}$.

Há quem prefira a expressão “dever-poder” em vez de "poder-dever”, para assim mais realçar a subordinação desse dever em relação ao poder ${ }^{3}$.

Esse poder-dever da Administração de punir infrações de seus servidores, chamado poder disciplinar, prescinde, em princípio, de um rol de condutas definidas em lei, cada qual com a respectiva cominação de sanção, ao contrário do que se passa no direito penal, no qual vigora o princípio nullum crimen, nulla pœena sine lege. Além disso, a autoridade investida do poder disciplinar, tendo em vista a gravidade do fato a ser punido, pode escolher dentre as penas previstas em lei a mais adequada a reprimir a falta cometida, sob o ponto de vista do interesse do serviço público. Nesse sentido, pode-se falar em discricionariedade, que não se confunde com arbitrariedade; porquanto a pena imposta à infração disciplinar é sempre escolhida dentre as várias cominadas em lei, mediante decisão motivada e precedida do devido procedimento legal ${ }^{4}$.

\footnotetext{
${ }^{1}$ F. J. Caldas Aulete, Dicionário contemporâneo da língua portuguesa, v. II, Parceria Antonio Maria Pereira, Lisboa, 1948, $3^{\text {a }}$ ed., p. 889.

${ }^{2}$ H. LOPES MeIRElles, Direito administrativo brasileiro, Malheiros, São Paulo, $34^{\text {a }}$ ed., 2008, p. 126-7.

${ }^{3}$ C. A. BAndeIRA DE Mello, Curso de direito administrativo, Malheiros, São Paulo, $27^{\mathrm{a}}$ ed., 2010, p. 72.

${ }^{4}$ H. LOPES MEIRELLES, Direito administrativo brasileiro cit., p. 127-9.
} 
Porém, embora o direito administrativo disciplinar não seja tipológico como o direito penal, porque visa a preservar a moral administrativa e o interesse público, há nele necessariamente a descrição de determinadas condutas ilícitas ${ }^{5}$.

No caso específico da Magistratura, por tratar-se de um ramo do serviço público que as Constituições normalmente revestem de garantias especialíssimas, cujo objetivo é assegurar a justiça e imparcialidade nos julgamentos proferidos por seus membros, o exame dos valores daqueles que exerceram o controle da disciplina dos juízes ao longo da história se mostra fundamental.

Na impossibilidade material de cotejar, por suas diversas variáveis de legislação e costumes, o exercício do controle disciplinar da magistratura em todo o Brasil, esta pesquisa se restringe ao território paulista.

Porém, essa restrição não pode ser considerada em termos absolutos, em razão das muitas alterações de limites que a terra paulista sofreu desde a fundação de seu primeiro núcleo, a Vila de São Vicente, até sua configuração atual. E mais, os juízes paulistas já estiveram subordinados a órgãos jurisdicionais e disciplinares com sede em Salvador e no Rio de Janeiro; e, até a proclamação da República, o território paranaense esteve sob a jurisdição do Tribunal de São Paulo.

Ao tratar dos sucessivos textos normativos que se propuseram a estabelecer o comportamento desejável dos juízes, bem como dos diversos pontos de vista dos doutrinadores que se debruçaram sobre esse tema, nossa reflexão tenta identificar possíveis valores permanentes para a função jurisdicional, diferenciando-os daqueles que meramente respondem a situações momentâneas.

A ideia de que o exercício da Magistratura é, muito mais que administrar a justiça, o cumprimento de deveres tanto profissionais como pessoais, é constante na história do Poder Judiciário. O discurso proferido na instalação do Tribunal da Relação de São Paulo, por seu primeiro presidente, o Conselheiro Tristão de Alencar Araripe, definia os desembargadores como "homens votados a um só culto - o do dever, a uma só aspiração a da honra"6.

Este trabalho é uma tentativa de compreender quais são esses deveres, em cujo rigoroso cumprimento consiste a honra de um magistrado.

\footnotetext{
${ }^{5}$ E. MAIA LuZ, Direito administrativo disciplinar, RT, São Paulo, $3^{\text {a }}$ ed., 1994, p. 83.

${ }^{6}$ F. TORRES, Tribunal de Justiça de São Paulo - páginas de sua história centenária, São Paulo, 1979, p. 16.
} 


\section{O CONTROLE DISCIPLINAR DA MAGISTRATURA NO PERÍODO COLONIAL PAULISTA}

\subsection{ALGUMAS PECULIARIDADES DA HISTÓRIA PAULISTA}

\subsubsection{Paulistas e nobres}

Ao escrever sobre a fundação da Vila de São Vicente em sua célebre História do Brasil, Fr. V. DO SAlvador afirmou que Martim Afonso de Sousa "a povoou de mui nobre gente que consigo trouxe, e assim floresceu em mui breve tempo",

Um século e meio depois, tendo examinado toda a documentação a que teve acesso, FR. G. DA MADRE DE DEUS identificou vinte e sete fidalgos dentre os colonizadores de São Vicente e argumentou que esse número deveria ser bem maior, pois não era verossímil que fossem apenas esses os nobres que a povoaram, na medida em que muitos autos e livros de cartório se perderam e, nos que se conservaram, algumas folhas se romperam e outras se tornaram ilegíveis. Além disso, havia pessoas que ora eram mencionadas com título, ora sem ele, em documentos lavrados pelo mesmo escrivão ${ }^{8}$.

Esses fidalgos ostentavam esse grau antes de 1572, ano em que foi admitida a nobilitação daqueles que exerciam ofícios mecânicos. Portanto, na época de Martim Afonso de Sousa, esse título ainda correspondia a um grau superior na fidalguia ${ }^{9}$.

Durante todo o período colonial brasileiro, a nobreza era transmitida por hereditariedade. E, de acordo com as Ordenações Filipinas, vários cargos do Reino de Portugal só poderiam ser ocupados por pessoas de alto nascimento, tais como o de Regedor da Casa da Suplicação, Chanceler-Mor, Meirinho-Mor, Meirinho que anda na Corte, Governador da Casa do Porto etc. ${ }^{10}$.

\footnotetext{
${ }^{7}$ FR. V. DO SALVADOR, História do Brasil 1500 - 1627, Itatiaia - USP, Belo Horizonte - São Paulo, $7^{\mathrm{a}}$ ed., 1982, p. 105.

${ }^{8}$ FR. G. DA MADRE DE Deus, Memórias para a história da Capitania de São Vicente, USP - Itatiaia, São Paulo - Belo Horizonte, 1975, p. 62-83.

${ }^{9}$ M. B. NizZA Da Silva (org.), História de São Paulo colonial, UNESP, São Paulo, 2009, p. 28. Ofícios mecânicos são os de carpinteiro, pedreiro, alfaiate, sapateiro etc. (cf. R. BLUTEAU, Vocabulario portuguez \& latino, aulico, anatomico, architetonico..., Coimbra, Collegio das Artes da Companhia de Jesus, 1712 1728 , v. 5, p. 380).

${ }^{10}$ Ordenações Filipinas, Livro I, títulos I, II, XVII, XXI e XXXV.
} 
Por outro lado, as Ordenações Filipinas proibiam que fidalgos e cavaleiros advogassem ou servissem de procurador de outrem, salvo em favor de pessoas sob sua dependência, seus caseiros, amos e mordomos. Nessas exceções, deveriam comparecer à audiência sobriamente e dirigir-se ao juiz e à parte contrária com brandura; caso contrário, o juiz deveria mandá-los embora, proibindo-os de retornar, sob a pena que lhe parecesse razoável. E, se voltassem à audiência depois disso, essa pena seria executada em seus bens. A razão de ser dessa proibição está na influência que o prestígio social de tais pessoas poderia exercer sobre o juiz, o qual deveria conservar a imparcialidade ${ }^{11}$.

A. TeIXEIRA DE FreITAS, no art. 466 da Consolidação das leis civis, ao enumerar os que "não podem ser procuradores em Juízo", não mencionou os fidalgos e cavaleiros, justificando em nota de rodapé que a vedação com relação a eles não era compatível com a nova ordem jurídica ${ }^{12}$.

Porém, C. MENDES DE AlmEIDA, em 1870, em nota ao título XXVIII do Livro III das Ordenações Filipinas, refutou essa posição, afirmando que, embora o prestígio da nobreza no Brasil nunca tenha sido tão grande quanto na Europa, nem fosse no século XIX o mesmo que nos anteriores, ainda pesava muito, de modo que era de interesse público manter a proibição, que não fora revogada, de os nobres e fidalgos advogarem ${ }^{13}$.

Os estudos sobre a origem nobre das elites paulistas perpassaram mais de quatro séculos da história de São Paulo, exercendo considerável influência na cultura e nos valores dessa sociedade.

Ainda na segunda metade do século XVIII, P. TAQues de Almeida PAEs Leme redigiu a Nobiliarquia paulistana, estudo genealógico sobre a descendência dos primeiros colonizadores, que lhe custou vários anos de pesquisas ${ }^{14}$.

No século XIX, alguns escritores tentaram desacreditar Frei Gaspar da Madre de Deus e Pedro Taques de Almeida Paes Leme, acusando o primeiro de "povoar as terras vicentinas de aristocratas"; e o segundo, de "arquitetar uma série de fábulas para dar

\footnotetext{
${ }^{11}$ Ordenações Filipinas, Livro I, título XLVIII, § 22, e Livro III, título XXVIII.

${ }^{12}$ A. TeIXEIRA DE FReITAS, Consolidação da leis civis, Garnier, Rio, $3^{\mathrm{a}}$ ed., 1896. Note-se que a edição por nós consultada é posterior à crítica de C. Mendes de Almeida, de 1870, e também posterior à proclamação da República, em 1889. Portanto, a "nova ordem de cousas" a que se referia A. Teixeira de Freitas não era a República, que então estava ainda longe de ser proclamada. Porém, com a proclamação da República, e a consequente abolição de todos os títulos nobiliárquicos, essa proibição foi, sem dúvida, derrogada pela "nova ordem de cousas".

${ }^{13}$ C. Mendes DE AlmeIDA, Codigo Philippino ou ordenações e leis do reino de Portugal, $2^{\circ}$ T., edição facsimilar da 14 a ed. de 1870, Senado Federal, Brasília, 2004, p. 612.

${ }^{14}$ P. TAQUES DE ALMEIDA PAES LEME, Nobiliarquia paulistana histórica e genealogica, T. I, Livraria

Martins, São Paulo, $3^{\mathrm{a}}$ ed., [s. d.], p. $11-36$.
} 
aparência de verdade às abusões nascidas da sua megalomania regional". Houve quem imputasse aos dois historiadores "mania nobiliárquica" e "prurido da vaidade, frequente entre os genealogistas e atávica entre paulistas". Porém essas acusações foram refutadas por A. DE Escragnolle TAUnAy, o qual demonstrou que elas se apoiavam em conjecturas, não em documentos ${ }^{15}$.

A polêmica foi provocada pela afirmação dos dois historiadores setecentistas de que houve mulheres brancas entre os primeiros povoadores da Capitania de São Vicente, afirmação esta que foi veementemente combatida por escritores do século XIX. Posteriormente, A. DE ESCRAGNOLLE TAUNAY comprovou, mediante diversos documentos, que houve, sim, mulheres brancas entre os primeiros colonizadores paulistas ${ }^{16}$.

No início do século XX, L. G. DA SILVA LEME publicou a Genealogia paulistana, em nove volumes, que lhe custaram mais de doze anos de pesquisas em cartórios de São Paulo e de alguns outros Estados. Ao apresentar sua obra, esse autor afirmou que seu objetivo fora "despertar os brios" das novas gerações para que sigam o exemplo de seus avoengos na prática de "atos de heroísmo e abnegação pela causa pública"17.

Em 1944, F. DE BARRos BROTERO escreveu a primeira obra sobre a história da Corte de Justiça paulista, Tribunal de Relação e Tribunal de Justiça de São Paulo sob o ponto de vista genealógico - aditamentos a Silva Leme, estudo genealógico sobre todos os desembargadores de São Paulo, desde a instalação do Tribunal da Relação, em 1873, até a composição do Tribunal de Justiça da época em que esse livro foi escrito. Em seu prefácio, esse autor justificou que a opção por uma obra genealógica tinha por objetivo colocar "a família como pedestal de toda a organização social", de modo a transmitir para as gerações futuras "paradigmas de integridade e exemplos de virtudes"18.

Por esse estudo, pode-se verificar que muitos desembargadores paulistas dos séculos XIX e XX descendiam dos primeiros colonizadores vicentinos. Nesse contexto, não parece sem importância o fato de que, ainda hoje, em muitos discursos proferidos nas sessões solenes do Tribunal de Justiça, os juízes do Estado de São Paulo sejam chamados de "magistratura bandeirante", apesar de entre o fim do período das bandeiras e a instalação daquela Corte haver decorrido um espaço de quase três séculos.

\footnotetext{
${ }^{15}$ A. DE Escragnolle Taunay, São Paulo cit., p. 384-385.

${ }^{16}$ A. DE Escragnolle Taunay, São Paulo cit., p. 385-395.

${ }^{17}$ L. G. DA SILVA Leme, Genealogia paulistana, $1^{\text {o }}$ vol., Duprat e Cia., São Paulo, 1903, p. III - IV.

${ }^{18}$ F. DE BARros Brotero, Tribunal de Relação e Tribunal de Justiça de São Paulo, São Paulo, 1944, p. 7-8.
} 
Em um dos momentos mais dramáticos da história de São Paulo, no qual o Tribunal de Justiça teve intensa participação, a Revolução de 1932, foi justamente a imagem do bandeirante que foi evocada como capaz de alimentar os ideais paulistas. Tudo isso é reflexo de valores e é impossível dissociar valor de comportamento.

A persistência do interesse genealógico e nobiliárquico entre os membros da Corte de Justiça paulista, mesmo muitas décadas após a proclamação da República, diz muito sobre os valores tradicionalmente predominantes em parte significativa de nossa elite judiciária.

Não se trata, obviamente, de "vaidade e mania nobiliárquica", a qual seria, como já se mencionou, “atávica entre paulistas”. O apreço das elites de São Paulo por suas origens aristocráticas pode evidenciar o apego não a privilégios que se tornaram odiosos com os ideais atualmente em voga, mas a tradições e costumes absolutamente necessários ao desenvolvimento sadio de qualquer sociedade, tal como ensinou o Papa Pio XII, para quem há um privilégio que não pode ser retirado de ninguém que não o consinta, o de ser “o melhor": melhor não na quantidade de riquezas, no luxo das vestes e no fausto dos palácios, mas na integridade dos costumes, na retidão da vida religiosa e civil, nas qualidades excelsas da mente e do coração, nas ações dignas de servir de exemplo e emulação ${ }^{19}$.

\subsubsection{Paulistas e índios}

Os primeiros colonizadores encontraram no território paulista, além de índios, alguns europeus, tais como João Ramalho, que vivia maritalmente com a índia Bartira, também chamada M’bicy, depois batizada com o nome de Isabel, filha do cacique Tibiriçá; e Antônio Rodrigues, que aqui vivia com índia filha do cacique Piquerohy, que foi batizada com o nome de Antônia. Muitos portugueses se uniram em matrimônio com as filhas desses casais e com outras índias, filhas de caciques, das quais descendem numerosas famílias paulistas ${ }^{20}$.

\footnotetext{
${ }^{19}$ Discorso di Sua Santità Pio XII al patriziato e alla nobiltà romana, 8 gennaio 1940, disponível em http://www.vatican.va/holy father/pius xii/speeches/1940/documents/hf_p-xii_spe 19400108 nolbiltaromana it.html

${ }^{20}$ L. G. DA SILVA LEME, Genealogia paulistana cit., $1^{\circ}$ v., p. 1.
} 
Assim que souberam que uma nau portuguesa aportara no local em que seria fundada a Vila de São Vicente, João Ramalho e Antonio Rodrigues para lá se dirigiram, levando consigo seus sogros, os caciques Tibiriçá e Caiubi, e cerca de quinhentos índios Guaianazes que habitavam o planalto de Piratininga. Celebrou-se uma aliança entre esses silvícolas e os portugueses, a qual foi festejada com danças, disparos de setas e estrondos da $\operatorname{artilharia~}^{21}$.

Não obstante esse pitoresco primeiro encontro, os primeiros habitantes da Capitania de São Vicente e os jesuítas, por quase dois séculos, disputaram intensamente a chamada "administração dos índios", que muito se assemelhava a cativeiro e teve importantes reflexos na história paulista.

Em 1567, o Padre Manuel da Nóbrega, em um parecer enviado à Mesa da Consciência, denunciou abusos contra os silvícolas. Em 20 de março de 1570, o Rei Dom Sebastião promulgou em Évora uma lei, considerada a primeira relativa à proteção dos índios, proibindo o cativeiro destes, salvo quando capturados em guerra justa. Para que uma guerra fosse justa, ela deveria ser previamente autorizada pelo Rei ou pelo Governador, e essa autorização só seria dada contra índios antropófagos que costumassem atacar portugueses ou outros índios. Os índios tornados cativos na forma dessa lei deveriam ser registrados, no prazo de dois meses, nos livros dos provedores, caso contrário ficariam "livres e forros" 22 .

Na Provisão de 20 de novembro de 1575, Dom Sebastião condenou o abuso de não se pagar a jornada inteira aos índios que se ausentavam de seu Termo por mais de um mês para trabalhar em fazendas distantes. Assim, o Rei demonstrava preocupação com que esses índios não pudessem voltar para as suas aldeias pela falta do pagamento, o que faria que essas aldeias se despovoassem, e também que esses índios, uma vez afastados de suas famílias, deixassem suas mulheres e se envolvessem com outras que não as suas ${ }^{23}$.

Filipe I, pela Lei de 22 de agosto de 1587, que foi publicada em Lisboa, na Chancelaria-Mor, em 15 de março de 1588, confirmou a Lei de 20 de março de 1570 e dispôs as condições pelas quais o Governador poderia dar licença a pessoas de bondade e qualidade para, acompanhadas de dois ou três jesuítas, buscar índios para trabalhar, mediante pagamento, em engenhos e fazendas. Esses índios deveriam ser trazidos sem

\footnotetext{
${ }^{21}$ A. LeITE, História da civilização paulista cit., p. 21; Fr. G. DA MADRE DE DEUS, Memórias cit., p. 53 - 56.

${ }^{22}$ I. J. CASAS DE NORONHA, Aspectos do direito no Brasil quinhentista, Almedina, Coimbra, 2005, p. 157-8.

${ }^{23}$ I. J. CASAS DE NORONHA, Aspectos do direito no Brasil quinhentista cit., p. 160-1.
} 
violência ou fraude, e quando quisessem se retirar, poderiam fazê-lo livremente. Eles seriam visitados duas vezes ao ano pelo Ouvidor Geral, o qual verificaria como são tratados e se são instruídos na doutrina cristã, e garantiria a liberdade aos que não se sentissem satisfeitos ${ }^{24}$.

Outra Lei de Filipe I, registrada em 9 de dezembro de 1595, revogou as leis anteriores e estabeleceu que a única causa para o cativeiro do gentio era a guerra justa, desde que assim declarada por Provisão Régia; ou seja, a decisão sobre a justiça ou não da guerra não podia mais ser tomada pelo Governador, mas apenas pelo próprio Rei, o que dificultava e procrastinava ainda mais sua obtenção ${ }^{25}$. Essa lei foi registrada na Câmara de São Paulo em 26 de junho de $1596^{26}$.

As Ordenações Filipinas, no Livro IV, título, XLII, estabeleceram que ninguém poderia ser obrigado a morar ou povoar determinado local, porque tal obrigação parecia espécie de cativeiro.

Pela Provisão de 5 de junho de 1605, Filipe II proibiu a escravização de índios, sem qualquer exceção ${ }^{27}$.

A Lei de 30 de julho de 1609 declarou livres todos os gentios do Brasil ${ }^{28}$.

Todavia, outra lei, de 1611, admitiu o cativeiro de índios, desde que tornados prisioneiros de guerra. Nesse mesmo ano, em 15 de agosto, começaram as hostilidades entre a Câmara de São Paulo e os Jesuítas ${ }^{29}$.

Nos inventários entre 1578 e 1609, os índios não só eram inventariados como eram a principal riqueza dos habitantes da Vila de São Paulo. Com a nova legislação, começaram as discussões jurídicas sobre a possibilidade de fazer constar ou não os índios "forros" nos inventários e partilhá-los entre os herdeiros. Isso porque, até então, tanto os índios escravos como os forros constavam nos inventários, os primeiros avaliados, os segundos, não, pois a única diferença entre eles era que os escravos podiam ser vendidos.

\footnotetext{
${ }^{24}$ I. J. CASAS DE NORONHA, Aspectos do direito no Brasil quinhentista cit., p. 183-4.

${ }^{25}$ I. J. CASAS DE NORONHA, Aspectos do direito no Brasil quinhentista cit., p. 191-2.

${ }^{26}$ A. LEITE, História da civilização paulista cit., p. 42.

${ }^{27}$ I. J. CASAS DE NORONHA, Aspectos do direito no Brasil quinhentista cit., p. 199-200.

${ }^{28}$ I. J. CASAS DE NORONHA, Aspectos do direito no Brasil quinhentista cit., p. 201. Observe-se que A. LeITE menciona lei desse teor datada de 31 de dezembro de 1601, a qual teria chegado ao conhecimento dos paulistas em 1602 e muito os irritara; mas também menciona em seguida a Lei de 30 de julho de 1609 (História da civilização paulista cit., p. 45, 46).

${ }^{29}$ A. LeITE, História da civilização paulista cit., p. 47.
} 
Essas discussões jurídicas estiveram presentes em inventários durante todo o século $\mathrm{XVII}^{30}$.

Em 13 de junho de 1640, ante a notícia de que o superior da Companhia de Jesus aportara no Rio de Janeiro, vindo de Roma, com uma Bula do Papa Urbano VIII, pela qual a direção dos índios ficava exclusivamente entregue à sua Ordem Religiosa, os jesuítas foram violentamente expulsos de seu Colégio em São Paulo. No ano seguinte, os paulistas escreveram a D. João IV, explicando os motivos dessa expulsão. O Rei respondeu em 1647, concedendo o perdão, desde que os jesuítas fossem restituídos aos seus colégios na Capitania, e que ficassem com a jurisdição dos índios no que toca à parte espiritual, e o governo das aldeias ficaria a cargo de seculares. Então, em 1653, graças à intervenção de João Pires Rodrigues, os jesuítas puderam retornar à Vila de São Paulo ${ }^{31}$.

Ao longo de todo o século XVII, continuou o apresamento de índios, com sucessivas idas e voltas da legislação e intermináveis conflitos entre paulistas e jesuítas relativos à questão indígena. A cronologia que segue, extraída de A. LEITE, permite vislumbrar a intransigência de um e outro lado e as oscilações da Coroa, ora abolindo o cativeiro dos índios, ora o permitindo sob determinadas condições.

Em 1607, os padres Jerônimo Rodrigues e J. Lobato, que transportavam pelo mar cento e cinquenta índios de Santa Catarina para o Rio de Janeiro, arribaram em Santos por causa de uma tempestade marinha, ocasião em que esses índios lhes foram arrebatados pelo Capitão daquela Vila e distribuídos à população.

Em 15 de agosto de 1611, a Câmara da Vila de São Paulo pela primeira vez hostilizou os jesuítas. Em 1612, a Câmara e o povo de São Paulo, sob a liderança de Amador Bueno, representaram à Metrópole contra a intromissão dos jesuítas na questão dos índios.

Em 1614, o paulista Pedro Domingues, que caçava índios no norte do Brasil, atingiu o Rio Guapará, no atual Pará.

Em 20 de janeiro de 1624, houve alvoroço e violência em sessão da Câmara de São Paulo que tratou da questão dos índios.

Em 1625, missões jesuíticas foram atacadas por paulistas entre os Rios Paraná e Uruguai.

\footnotetext{
${ }^{30}$ M. B. NizZA DA Silva (org.), História de São Paulo colonial cit., p. 57-8.

${ }^{31}$ L. G. DA Silva Leme, Genealogia paulistana, V. II, Duprat e Cia., São Paulo, 1904, p. 134-5.
} 
Em 1631, Pedroso de Morais, Antonio Raposo e outros bandeirantes atacaram Guaíra, entre os Rios Paraná e Paraguai, apreendendo oitenta e oito mil índios, dos cem mil que povoavam essa região ${ }^{32}$.

Em 1636, Antonio Raposo Tavares atacou as missões jesuíticas no Rio Grande do Sul. No ano seguinte, os padres jesuítas Francisco Dias Taño e Antônio Ruiz Montoya foram a Madri e a Roma e imploraram de joelhos ao Papa e ao Rei medidas contra os "bárbaros mamelucos de São Paulo".

O Papa Urbano VIII, em 22 de abril de 1639, pelo Breve Comissum Nobis, insistiu na liberdade dos índios.

Em 31 de março de 1640, o Rei novamente publicou uma lei determinando a alforria dos índios cativos. Nesse ínterim, em 20 de novembro de 1639, os habitantes da Vila de São Paulo expulsaram o vigário, Padre Manuel Nunes que, solidário com os jesuítas, os excomungara por causa da questão com os índios. Franciscanos, beneditinos e carmelitas tomaram o partido dos paulistas contra os jesuítas.

Em setembro de 1641, o Governador Salvador Correia de Sá e Benevides tentou repor os jesuítas à Capitania de São Vicente, mas foi desacatado pelos paulistas, que o fizeram retornar de Santos para a Guanabara. Nesse mesmo ano, os paulistas Luís da Costa Cabral e Baltasar da Borba Gato, em visita a Dom João IV, relataram ao monarca "as atrocidades dos jesuítas".

Em 3 de outubro de 1642, Dom João IV, por Alvará, determinou o retorno dos jesuítas à Capitania de São Vicente; os quais retornam a Santos no mesmo ano; mas, quanto às demais propriedades desses religiosos, esse Alvará foi desobedecido.

Em 1645, os Oficiais da Câmara de São Paulo escreveram ao Papa, explicando a necessidade de terem os índios sob sua sujeição, para que pudessem cultivar a terra e continuar a socorrer com carne, legumes e trigo o resto do Brasil e Angola.

Em 1646, os Camargos desceram a Santos para hostilizar os jesuítas.

\footnotetext{
${ }^{32}$ Esses números referidos por AURELIANO LEITE foram baseados em Charlevoix, autor severamente criticado por FREI GASPAR DA MADRE DE DEUS, que, depois de apontar diversas inverdades na História do Paraguai, afirma: "As paixões cegam os homens e ofuscam os entendimentos. Charlevoix era Jesuíta; tinha lido nos escritos de seus sócios as conquistas dos paulistas nas Aldeias sujeitas à extinta Companhia de Jesus, quando principalmente estávamos em guerra com a Espanha: sabia que os paulistas expulsaram da sua Capitania os mesmos Jesuítas: esta injúria era muito sensível a tôda a Sociedade: os seus indivíduos não se descuidaram de encobrir as verdadeiras causas do seu extermínio e de representarem nos seus escritos os paulistas como iníquos depravados, para que somente sôbre eles recaísse todo o opróbrio. Tôdas estas razões de tal sorte enfureceram Charlevoix contra os moradores da Capitania de S. Vicente, que lhe faltaram as luzes intelectuais necessárias para discernir o verdadeiro do falso" (FR. G. DA MADRE DE DEUS, Memórias cit., p. 105)
} 
Em 1647, o Padre Domingos Homem Albernaz, partidário dos jesuítas, excomungou a população de São Paulo e abandonou a Paróquia; os paulistas o hostilizaram, escrevendo-lhe longo abaixo-assinado e lhe obstando o Caminho do Mar; esse padre, que em diversas ocasiões demonstrou ser "homem de grande atrevimento", foi deposto em 1654, tentou voltar em maio do ano seguinte, mas foi repelido pelo povo.

Em 1648, os religiosos da Ordem do Carmo mandaram apresar índios para o serviço de seu convento.

Em 26 de outubro de 1659, o Padre Geral da Companhia de Jesus, Gosvíneo Nkicel, escreveu à Câmara de São Paulo uma carta de agradecimento pela amizade aos jesuítas.

Em 1661, Fernão Dias Paes trouxe cinco mil índios de Apucarana para São Paulo.

Em março de 1662, uma carta régia proibiu mais uma vez o cativeiro de índios, salvo quando feitos prisioneiros de guerra. No ano seguinte, o Governador da Bahia, Alexandre de Souza Freire, convidou o paulista Pedro Vaz de Barros para guerrear contra índios rebelados; anos antes, outro paulista, Domingos Calheiro, não alcançara sucesso nessa guerra.

Em 1665, o Padre Mateus Nunes de Siqueira, com índios oriundos da aldeia de Guarulhos, deu início a uma aldeia na localidade hoje conhecida como Atibaia.

Em 1670, Estevão Bayão Parente foi convidado a guerrear contra índios sublevados na Bahia; no ano seguinte, o Governador, a Relação e a Câmara da Bahia agradeceram à Câmara de São Paulo pela ação bélica de Estevão Bayão Parente, o qual, auxiliado por Pedro Vaz de Barros, libertara aquela região de índios que a assolavam.

Em 26 de agosto de 1680, Dom Pedro, Príncipe Regente de Portugal, aconselhado pelo jesuíta Padre Antônio Vieira, proclamou de novo a abolição do cativeiro indígena, e determinou que a administração dos índios fosse entregue, tanto no temporal como no espiritual, aos jesuítas, o que provocou sérios tumultos em São Paulo no ano seguinte, quando essa lei foi publicada.

Em 28 de março de 1682, novos tumultos ocorreram em São Paulo contra a entrega dos índios aos jesuítas.

Em 1684, os jesuítas anunciaram que pretendiam se retirar do Colégio de São Paulo, o que provocou tumultos e ameaças entre o povo; a Câmara, em 2 de novembro, dirigiu-se a esses religiosos, pedindo que desistissem dessa ideia. 
Em 1685, sob a mediação do Bispo do Rio de Janeiro, Dom José de Barros Alarcão, e do Capitão-Mor Pedro Taques de Almeida, os paulistas celebraram um acordo com os jesuítas, relativo à “descida do gentio". Esse acordo será renovado em 1687 e homologado pela Carta Régia de 9 de novembro de 1690.

Em 1689, Matias Cardoso de Almeida atacou índios revoltados em São Francisco, Ceará e Rio Grande no Norte; anos depois, ele guerreou com índios no Rio Grande do Sul.

Em janeiro de 1694, mais um acordo relativo aos índios é assinado entre os jesuítas, representados por seu Provincial, Padre Alexandre de Gusmão, e os paulistas, representados por seus magistrados e vereadores.

Em 12 de julho de 1694, o Padre Antônio Vieira, da Bahia, escreveu um parecer contra os paulistas sobre a questão dos índios ${ }^{33}$.

Somente em 1696, quando D. Pedro II determinou, por meio das Cartas Régias de 26 de janeiro e 19 de fevereiro, que os índios poderiam continuar a ser legalmente administrados, cessaram definitivamente as contendas entre jesuítas e paulistas ${ }^{34}$.

A liberdade definitiva dos índios só seria assegurada pelos Alvarás de $1^{\circ}$ de abril de 1755 e 8 de maio de 1758, de Dom José I, no governo de Sebastião José de Carvalho e Melo, depois Marquês de Pombal. E, conforme o Decreto de 4 de abril de 1755, os que se casassem com índios não teriam infâmia, antes se fariam dignos das atenções régias para empregos e honras ${ }^{35}$.

Sobre o longo conflito entre jesuítas e paulistas escreveu FR. G. DA MADRE DE DEUS:

"É certo que os moradores da Capitania de S. Vicente, principalmente os de Serra acima, se esqueceram algumas vezes das Leis Divinas e humanas, respectivas à inteira liberdade dos índios: mas é necessário confessar que a esperança moralmente certa do perdão, e a experiência das condescendências tantas vezes praticadas nesta matéria, por interesse do Estado, principalmente de descobrimentos de ouro, sumariamente recomendados pela Corte aos paulistas, foi a causa principal de transgredirem as leis, abusando daqueles únicos casos em que as mesmas permitiam o cativeiro ou a Administração dos Índios. Porém é certo, também, que se os antigos habitantes da dita Capitania foram até certo tempo repreensíveis a este respeito, não o foram menos os outros portugueses das outras colônias brasílicas, principalmente os do Maranhão e Pará, como consta de alguns de nossos autores e dos Arquivos das mesmas e das Leis promulgadas em diferentes tempos sôbre os mesmos índios. Há, contudo, uma circunstância que faz

\footnotetext{
${ }^{33}$ A. LEITE, História da civilização paulista cit., p. 46-67.

${ }^{34}$ M. B. NiZZA DA SILVA (org.), História de São Paulo colonial cit., p. 57; A. LeITE, História da civilização paulista cit., p. 67.

${ }^{35}$ A. LeITE, História da civilização paulista cit., p. 92.
} 
grande diferença neste caso: os paulistas tiveram a desgraça (se tal nome aqui convém) de se embaraçarem com os Jesuítas do Paraguai e da sua Capitania; e, por consequiência, de ofenderem toda a Sociedade cujos Escritos voaram por tôda a parte a denegrí-los à face do Universo. Mas, em fim, o tempo veio a manifestar que êstes mesmos Jesuítas, que tanto clamaram a favor dos Indígenas da América, foram os que na maior parte dela os tiveram em uma rigorosa sujeição; do qual os livraram nos Estados do Brasil e Pará as providentes leis, que a bem daqueles pobres Vassalos mandou promulgar o Snr. Rei D. José de gloriosa memória"36.

Fugiria ao propósito deste trabalho uma inquirição mais aprofundada sobre esse conflito que perpassou praticamente todo o século XVII.

A fundamentação moral para as repetidas abolições do cativeiro indígena remonta, segundo I. J. CASAS DE NORONHA, à filosofia da segunda escolástica, em especial aos trabalhos do dominicano Francisco de Vitória, professor da Universidade de Salamanca, e do jesuíta espanhol Francisco Suárez, professor da Universidade de Coimbra. Ao primeiro se deve a argumentação de que não era lícito fazer guerra contra os índios e reduzi-los ao cativeiro pelo simples fato de eles serem pagãos, na medida em que, até então, eles estavam em situação de ignorância invencível, pois desconheciam a fé e a moral católicas ${ }^{37}$.

Mas, se por um lado os Reis de Portugal estavam convencidos da inadmissibilidade moral do cativeiro indígena, inadmissibilidade essa proclamada reiteradas vezes pelo supremo Magistério da Igreja; por outro, eram pressionados pela necessidade dos paulistas de se aproveitarem do trabalho dos índios; e pelos jesuítas, que a pretexto de defenderem esses índios, reivindicavam a autoridade sobre eles tanto em matéria espiritual quanto temporal. A essa reivindicação se opunham os paulistas, acusando os jesuítas de pretenderem ser os únicos beneficiários do trabalho indígena. Tal acusação era endossada por franciscanos, beneditinos e carmelitas, os quais - pelo menos os últimos - se beneficiavam largamente do trabalho dos silvícolas ${ }^{38}$.

Paulistas e jesuítas se dirigiram repetidas vezes ao Rei e ao Papa, cada qual com libelos veementes contra seu adversário, o que explica tantas oscilações da Coroa, que ora

\footnotetext{
${ }^{36}$ FR. G. DA MADRE DE DEUS, Memórias cit., p. 135-6.

${ }^{37}$ I. J. CASAS DE NORONHA, Aspectos do direito no Brasil quinhentista cit., p. 167-9.

${ }^{38}$ M. E. DE AZEVEDo MARQUES transcreve na íntegra cinco documentos do Arquivo do Convento do Carmo de São Paulo, datados de 28 de dezembro de 1648, 5 de janeiro de 1650, 24 de março de 1650, 5 de fevereiro de 1652 e 3 de maio de 1685, nos quais os carmelitas tratam do apresamento de índios para usá-los em seu serviço; e transcreve ainda uma petição, despachada em 7 de agosto de 1672, na qual o reitor do Colégio dos Jesuítas, Padre Manoel Pedroso, admite que tem a administração de alguns índios, dos quais se serve na lavoura de sua fazenda, bem como que chega a alugar índios de fora para esse serviço (Apontamentos cit., t. I, p. 341-3)
} 
proclamava a liberdade dos índios, ora admitia o cativeiro deles sob determinadas condições.

Não é lícito duvidar da retidão, por exemplo, de um Padre Antônio Vieira; mas seria ingênuo estender o respeito devido a esse grande jesuíta a todos os membros da Companhia de Jesus durante o extenso período desse conflito, ante a existência de documento que corrobora parte das acusações que os paulistas lhes faziam ${ }^{39}$.

Essa longa descrição do conflito entre paulistas e jesuítas sobre a questão indígena visa a ilustrar quão arraigado é, entre os primeiros, o espírito de autonomia. Não aceitavam eles que o rei, distante e alijado dos problemas locais, pudesse decidir sobre matéria tão importante ao seu estilo de vida com base apenas em considerações teóricas. Não houve movimentos separatistas, tanto que sumariamente rejeitada a proposta de coroação de Amador Bueno, mas foi afirmada, desde o século XVII, a convicção coletiva de que a elite paulista, a par de sua vassalagem à Coroa, era capaz de decidir sobre seus próprios rumos.

Tal sentimento ecoou com força na Revolução Constitucionalista de 1932, tão cara ao Tribunal paulista, que se proclama "justiça bandeirante", e ainda hoje é fonte de incompreensões por parte do Conselho Nacional de Justiça.

\subsubsection{Os paulistas e suas famílias}

A importância das relações familiares para os primeiros colonizadores paulistas se depreende da complexa teia de parentesco por eles formada: dos vinte e sete fidalgos conhecidos, somente três não eram comprovadamente aparentados de algum dos outros ${ }^{40}$.

Os casamentos muitas vezes eram precedidos de esponsais. Estes, celebrados sem a presença do sacerdote, para evitar qualquer confusão com o sacramento do matrimônio, prescindiam de formalidades escritas ou verbais, embora houvesse a tradição da entrega de arras esponsalícias. No entanto, os antigos paulistas costumavam oferecer documento escrito para comprovação dos esponsais; e frequentemente era desrespeitada a proibição canônica de coabitação antes de ser celebrado o casamento ${ }^{41}$.

\footnotetext{
${ }^{39}$ Vide nota de rodapé precedente.

${ }^{40}$ Fr. G. DA MADRE DE DEUS, Memórias cit., p. $65-81$.

${ }^{41}$ I. M. POVEDA VELASCO, Os esponsais cit., p. 201 - 203.
} 
A vida familiar paulista nos três primeiros séculos apresentava várias peculiaridades: os cônjuges eram selecionados por critérios étnicos, pois casamentos de brancos com pessoas de cor eram excepcionais e atingiam a honra da família; a idade núbil era entre 20 e 26 anos, sendo os homens de um a três anos mais velhos que suas mulheres; a busca de alianças familiares era importante motivação para o matrimônio; o dote era grande responsável pela transferência de bens entre os moradores do Planalto. Após o matrimônio, o poder na família era pelo homem e, em sua ausência, pela mulher; as atividades da mulher eram restritas a áreas consideradas apropriadas à natureza feminina; quanto melhor favorecida economicamente fosse a família, maior era o número de filhos; a submissão dos filhos era assegurada por educação severa, da qual faziam parte castigos corporais; incestos e bigamias eram investigados nas devassas; muitas vezes os filhos originados de adultérios eram reconhecidos no momento da morte; mancebias e concubinatos eram severamente repreendidos e podiam levar os culpados a julgamento pelo Tribunal Eclesiástico; nulidades matrimoniais e divórcios eram mal aceitos pela sociedade $^{42}$.

Além disso, era generalizada a preocupação dos paulistas em beneficiar as mulheres da família nos testamentos, inclusive sobrinhas, consanguíneas ou por afinidade, e ainda as descendentes ilegítimas; embora os filhos naturais, salvo os dos nobres, pudessem herdar como os legítimos, desde que reconhecidos em testamento, muitas vezes seu quinhão era tirado da parte disponível; as mulheres eram beneficiadas com o dote, o qual podia ser superior ao quinhão da herança, hipótese em que elas podiam recusar a herança para não ter que trazer o dote à colação; havia o costume generalizado de a viúva com menos de cinquenta anos se casar novamente, o que justificava que elas não fossem nomeadas tutoras dos filhos órfãos; os órfãos eram proibidos por lei de residir com o padrasto $^{43}$.

Toda a moral relativa ao casamento era disciplinada pela Igreja Católica, cuja doutrina matrimonial se encontra na encíclica Casti connubii, de Pio XI. Pode parecer anacronismo indicar um documento pontifício da primeira metade do século XX como compêndio para a compreensão das questões morais dos séculos XVI e XVII, mas não é, pois as normas da Igreja Romana em matéria de fé e moral são imutáveis, conforme o

\footnotetext{
${ }^{42}$ A. Lobo de ARruda CAmpos, Casamento e família em São Paulo colonial, Paz e Terra, São Paulo, 2003, p. $558-64$.

${ }^{43}$ M. B. NizZA DA Silva (org.), História de São Paulo colonial cit., p. 62-72. Só eram considerados órfãos aqueles a quem morrera o pai. Aqueles cuja mãe morrera eram chamados menores.
} 
princípio proclamado no século V por São Vicente de Lerins: Quod ubique, quod semper, quod ab omnibus ${ }^{44}$.

As normas de direito meramente positivo da Igreja podem variar em razão de peculiaridades de determinada época ou região, mas não a doutrina. Por exemplo, como o casamento entre parentes próximos era costume profundamente arraigado entre os antigos habitantes da Capitania de São Vicente, o Papa Pio IV, em 28 de janeiro de 1561, concedeu ao Bispo do Brasil a faculdade de dispensar de impedimentos matrimoniais os parentes por consanguinidade ou afinidade no quarto grau simples ou terceiro e quarto $\operatorname{mistos}^{45}$.

\subsubsection{Os paulistas e sua religião}

A religiosidade católica é característica importante dos primeiros colonizadores. Vários deles se preocuparam em edificar capelas em honra dos santos de sua devoção, inclusive estabelecendo encargo testamentário a seus herdeiros de conservação dessas capelas. No caso de Brás Cubas, além da doação de terreno para a construção de um convento, essa religiosidade se revelou no aspecto caritativo, com a fundação da Santa Casa de Misericórdia de Santos, apenas nove anos após a imigração para a capitania. E tudo isso em meio à adversidade de um continente ainda não colonizado ${ }^{46}$.

Na Vila de São Paulo, Pedro Dias Paes Leme financiou a construção da Igreja da Ordem Terceira do Carmo; seu filho, Fernão Dias Paes Leme fez doações de vulto ao Mosteiro de São Bento, onde foi sepultado e é tido por grande benfeitor; Manuel Preto erigiu a Capela de Nossa Senhora da Expectação do Ó; Domingos Luiz, a Capela de Nossa Senhora da Luz, e assim por diante. Em Parnaíba, Guilherme Pompeu de Almeida Leme ergueu a Capela de Nossa Senhora da Conceição.

\footnotetext{
44 "Na Igreja Católica é preciso pôr o maior cuidado para manter o que se crê em todas as partes, sempre e por todos. Eis o que é verdadeira e propriamente católico, segundo a ideia de universalidade que se encerra na própria etimologia da palavra. Mas isso será conquistado se nós seguirmos a universalidade, a antiguidade e o consenso geral. Seguiremos a universalidade se professarmos a única e verdadeira fé que a Igreja inteira professa em todo o mundo; a antiguidade, se não nos separarmos de nenhuma forma dos sentidos que foram proclamados por nossos santos predecessores e padres; o consenso geral, por último, se, neta mesma antiguidade, abraçarmos as definições e as doutrinas de todos, ou de quase todos, os bispos e mestres". (S. VICENTE DE LERINS, Comonitório - regras para conhecer a fé verdadeira, Permanência, Niterói, trad. do espanhol de Fabiano Lyrio Silva, 2009, p. 17).

${ }^{45}$ A. Lobo de ARRUda CAMPos, Casamento e família em São Paulo colonial cit., p. 201.

${ }^{46}$ Fr. G. DA MADRE DE DEUS, Memórias cit., p. 113 - 114.
} 
Apesar do desejo da Coroa de que não houvesse conventos femininos no Brasil, pois era necessário que as poucas mulheres brancas se casassem e tivessem filhos naqueles primeiros tempos, Manuel Vieira Barros doou casas para a formação do Recolhimento de Santa Teresa e ali colocou duas de suas filhas. Esse recolhimento contou também com a generosidade de Lourenço Castanho Taques, que tinha a intenção de que nele se enclausurassem suas descendentes ${ }^{47}$.

Além das paulistas que eram mandadas por suas famílias para o Recolhimento de Santa Teresa, houve algumas que foram enviadas a conventos na Europa, como o Mosteiro de Santa Clara, na cidade do Porto, ou o de São Bento, em Évora ${ }^{48}$.

Nos primeiros anos da Capitania, apenas São Vicente e Santos tinham vigário. O de São Paulo foi nomeado no final do século XVI, depois que a população angariou contribuições para a construção da Igreja Matriz. O quarto a ser nomeado foi o de Itanhaém, no início do século XVII ${ }^{49}$.

As irmandades, confrarias e ordens terceiras desempenhavam papel importantíssimo na sociedade colonial, seus membros eram sepultados em suas respectivas igrejas, com o acompanhamento dos demais associados. Para o ingresso em ordens terceiras exigia-se "pureza de sangue", além do pagamento de altas joias e anuidades. As irmandades agrupavam seus associados conforme a origem étnica: brancos, pardos, pretos e índios ${ }^{50}$.

Por volta de 1560, veio à Capitania de São Vicente um francês, Jean Cointa, Senhor de Boulez, o qual foi acusado pelos jesuítas de heresia, mas absolvido pelo vigário de Santos. Porém, por influência dos jesuítas, o Bispo da Bahia mandou prendê-lo assim que ele desembarcou em Salvador. Lá ele ficou preso alguns anos e, mandado para Lisboa, ficou livre das acusações em $1564^{51}$.

\subsubsection{As capitanias hereditárias que deram origem ao território paulista}

\footnotetext{
${ }^{47}$ M. B. NizZA DA SILVA, História de São Paulo colonial cit., p. 83.

${ }^{48}$ M. B. NizZA DA SILVA, História de São Paulo colonial cit., p. 126.

${ }^{49}$ M. B. NizZA DA SILVA, História de São Paulo colonial cit., p. $81-82$.

${ }^{50}$ M. B. NizZA DA Silva, História de São Paulo colonial cit., p. 84 e 128.

${ }^{51}$ M. B. NizZA DA SILVA, História de São Paulo colonial cit., p. 85 - 88.
} 
Em 1534, Dom João III decidiu colonizar o território brasileiro dividindo-o em quinze Capitanias Hereditárias que foram concedidas a doze insignes donatários, entre eles, os irmãos Martim Afonso e Pero Lopes de Sousa, que receberam, cada qual, mais de um lote . $^{52}$.

Essas Capitanias foram demarcadas por linhas paralelas ao Equador e representaram o primeiro esboço das Províncias e dos atuais Estados brasileiros O território do atual Estado de São Paulo compreende parte das Capitanias Hereditárias que por carta e foral datados de 6 de outubro de 1534 foram doadas a Martim Afonso e Pero Lopes de Sousa ${ }^{53}$.

A Capitania de São Vicente, doada a Martim Afonso de Sousa, era dividida em duas partes, pois nela ficava encravada a Capitania de Santo Amaro, medindo dez léguas, cujo donatário era Pero Lopes de Sousa. Assim, a parte setentrional da Capitania de São Vicente, medindo cinquenta e cinco léguas, começava na divisa com a Capitania de São Tomé, doada a Pero de Góis, e ia até o Rio Juqueriquerê, onde tinha início a Capitania de Santo Amaro. As outras quarenta e cinco léguas começavam no Rio Bertioga e terminavam doze léguas ao sul de Cananéia, em uma das três barras da Vila de Nossa Senhora de Paranaguá $^{54}$.

Houve um litígio entre o Conde de Monsanto, herdeiro de Pero Lopes de Sousa, e a Condessa de Vimieiro, herdeira de Martim Afonso de Sousa, que se arrastou por todo o século XVII. Durante essa disputa judicial, em 1623, a Relação da Bahia determinou a demarcação das duas Capitanias, as quais, de acordo com as cartas de doação, eram divididas pela barra do Rio São Vicente; porém, como esse rio tem três barras, a divisão foi feita pela barra sul, e não pela norte, que seria o limite correto. Por essa razão, durante o conflito, as Vilas de São Vicente, São Paulo e Santa Ana de Mogi foram atribuídas ao Conde de Monsanto. Despojada dessas vilas, a Condessa de Vimieiro, em 1624, transferiu a sede de sua Capitania para a Vila de Itanhaém ${ }^{55}$.

Esse litígio entre as casas de Vimieiro e de Monsanto, cujas capitanias ao longo da história acabaram por se fundir, contribuiu para que o território paulista, ao contrário da maior parte das demais capitanias, permanecesse na condição de capitania donatarial até 1709. Consequentemente, os paulistas, por sua maior autonomia, comparados aos

\footnotetext{
${ }^{52}$ I. M. POVEDA VELASCO, Os esponsais cit., p. 24-5.

${ }^{53}$ M. FLEIUSS, História administrativa do Brasil cit., p. 8 - 10.

${ }^{54}$ A. Barreto do Amaral, Dicionário de história de São Paulo cit., p. 154-5.

${ }^{55}$ M. B. NizZA DA Silva, História de São Paulo colonial cit., p. 13-17.
} 
habitantes das demais capitanias, frequentemente eram tidos por rebeldes e maus vassalos pelos governadores gerais e membros do Conselho Ultramarino. Para desfazer essa fama, no final do século XVIII, Frei Gaspar da Madre de Deus e Pedro Taques de Almeida Paes Leme se empenharam em demonstrar que os paulistas tinham sido sempre fiéis vassalos dos Reis de Portugal ${ }^{56}$.

Durante o litígio entre as casas de Vimieiro e de Monsanto, a Coroa portuguesa acabou por tomar algumas providências que competiam aos donatários. Exemplo disso é a Vila de Paranaguá, na qual, em 1646, se levantou o pelourinho, por ordem de Duarte Correia Vasqueanes, que então governava o Rio de Janeiro, portanto, representante da Coroa, não do donatário. A primeira eleição dos oficiais da Câmara dessa Vila se deu em 1648. Em 1654 e em 1656, tomaram posse perante a Câmara dois Capitães-Mores, ambos em nome do Conde da Ilha do Príncipe, sucessor da Condessa de Vimieiro, e, em 1660, tomou posse outro Capitão-Mor, em nome do Marques de Cascais, sucessor do Conde de Monsanto. Nesse mesmo ano de 1660, Salvador Correia de Sá foi a Paranaguá e determinou que a Vila se conservasse em nome do Rei, sem reconhecer nenhum dos donatários, ante a dúvida sobre a qual deles ela pertencia ${ }^{57}$.

\subsubsection{Vilas, aldeias e povoados}

O primeiro empreendimento de colonização do território brasileiro foi a fundação da Vila de São Vicente, em 22 de janeiro de 1532, por Martim Afonso de Sousa, cuja flotilha era composta por quatrocentos homens ${ }^{58}$.

Ao fundar a primeira vila brasileira, Martim Afonso de Sousa mandou erguer o pelourinho, a Câmara, a Igreja, a casa-forte etc. A Igreja Matriz e a Câmara de São Vicente foram tragadas pelo mar em 1542, o que obrigou os habitantes da povoação a procurar lugar mais seguro ${ }^{59}$.

O levantamento do pelourinho, símbolo da justiça e da autoridade do rei, era o ato oficial da fundação de uma vila ou cidade. Diante dele eram lidas as proclamações civis e

\footnotetext{
${ }^{56}$ M. B. NizZA DA SILVA (org.), História de São Paulo colonial cit., p. 19.

${ }^{57}$ M. B. NizZA DA SILVA (org.), História de São Paulo colonial cit., p. 37.

${ }^{58}$ M. FLeIUSS, História administrativa do Brasil, Imprensa Nacional, Rio, 1923, p. 6-7.

${ }^{59}$ A. LEITE, História da civilização paulista cit., p. 24
} 
castigados os delinquentes. Era, em regra, colocado no centro de qualquer município português do século XVI, de modo que sua posição topográfica indicasse que a principal responsabilidade régia era a administração da justiça ${ }^{60}$.

Exceção conhecida a essa regra foi a Cidade de Salvador, na qual o pelourinho foi de lá removido por ordem do Governador Diogo Botelho, o qual, por residir na praça defronte o local em que havia sido levantado, "se entristecia com a sua vista", uma vez que estivera prestes a ser degolado diante de um pelourinho por ter tomado o partido de Dom Antônio, Prior do Crato, um dos pretendentes à Coroa portuguesa na crise sucessória de 1580. Diogo Botelho acabou obtendo o perdão do Rei em razão de seu casamento com uma irmã de um secretário da Corte; e, em 1602, foi nomeado o oitavo Governador do Brasil $^{61}$.

As informações completas sobre a fundação da Vila de São Vicente constavam no livro grande, chamado Tombo, que havia no arquivo do cartório daquela vila, o qual foi incendiado $^{62}$.

A Capitania de São Vicente teve grande desenvolvimento ao longo dos séculos XVI e XVII, com a fundação de diversas Vilas e povoados.

Ainda em 1532, Martim Afonso construiu, a vinte e sete quilômetros de distância de Santos pelo sudeste, o Forte de São Tiago, depois chamado de São João, depois, de Santo Antônio, e depois Fortaleza da Bertioga. Ao redor dessa Fortaleza formou-se um povoado que, em janeiro de 1547, foi atacado pelos Tamoios, que devoraram os defensores do Forte. Nesse mesmo ano, os irmãos Braga reforçaram a trincheira que ali havia, auxiliados pelos Tupiniquins. No Forte, em 1550, o aventureiro, soldado e cronista alemão Hans Staden, que naufragara no ano anterior na costa de Itanhaém, foi preso durante dez meses e meio pelos Tamoios. Anos mais tarde, ele publicou um livro sobre suas aventuras. Depois de destruído e incendiado pelos Tamoios, o Forte foi novamente levantado em 1552, e reconstruído mais uma vez em 1557, desta vez por ordem de Jorge Ferreira, capitão-mor de São Vicente. Em tempo de paz, teria três homens; em tempo de guerra, um oficial, um inferior e vinte soldados de infantaria. Ao redor da Fortaleza formou-se um

\footnotetext{
${ }^{60}$ S. B. SCHWARTZ, Burocracia e sociedade no Brasil colonial, Companhia das Letras, São Paulo, $2^{\mathrm{a}}$ ed., 2011, p. 27-28.

${ }^{61}$ FR. V. DO SALVADOR, História do Brasil cit., p. 280-287.

${ }^{62}$ Esse incêndio foi provocado por Manoel Vieira Collaço, que então governava a Vila, e que enlouqueceu após seu pedido de casamento a D. Margarida Carvalho da Silva ser recusado (Cf. P. TAQUES DE ALMEIDA PAES LEME, Nobiliarchia paulistana cit., p. 139).
} 
povoado, do qual, em 1557, Pascoal Fernandes, um dos fundadores de Santos, foi nomeado condestável, passando a ali viver com sua família ${ }^{63}$.

A elevação de Itanhaém a Vila ocorreu em abril de 1561, pelo Capitão-Mor Francisco de Morais ${ }^{64}$. Enquanto permaneceu na condição de Cabeça de Capitania, ou seja, até 1679, foi a sede administrativa das regiões de Cabo Frio, Vale do Paraíba e do sul de Minas Gerais. Em 1654, foi construído ali um Convento de Franciscanos ${ }^{65}$.

A povoação de Santos teve início em 1536, por Brás Cubas, Paschoal Fernandes e Domingos Pires, em uma sesmaria doada ao primeiro por Martim Afonso em 1532. Brás Cubas convenceu o capitão-mor da Capitania de São Vicente a transferir para ali o antigo Porto de São Vicente, razão pela qual o local foi inicialmente conhecido como Povoado do Porto de São Vicente, dedicado ao cultivo de cana-de-açúcar. Em 1543, a Irmandade da Santa Casa de Misericórdia de Todos os Santos construiu ali o primeiro hospital do Brasil. Em $1545^{66}$, por Brás Cubas, que então exercia a função de capitão-mor da Capitania de São Vicente, lhe foi concedido o foral ${ }^{67}$, passando a se chamar Vila do Porto de Santos. Em 1553, quando foi visitada pelo governador-geral do Brasil, Tomé de Sousa, este comunicou a D. João III que ali estava o melhor porto "e todas as naus do mundo poderão estar nele". Tomé de Sousa chegou a cogitar a supressão da Vila de São Vicente, unificando-a à de Santos, pois a ilha era muito pequena para ter duas vilas; mas, porque São Vicente tinha "igreja muito honrada, e honradas casas de pedra e cal, com um colégio dos irmãos de Jesus", e em respeito a Martim Afonso, que a fundara, manteve as duas vilas $^{68}$.

${ }^{63}$ N. OdÁlia e J. R. DE CASTRo CAldeIRA (org.), História do Estado de São Paulo cit., v. III, p. 95; A. Barreto do Amaral, Dicionário de história de São Paulo cit., p. 110, 278 e 610-611; A. Leite, História da civilização paulista cit., p. 26 e 29.

${ }^{64}$ A. BARRETO Do AMARAL, Dicionário de história de São Paulo cit., p. 351; Fr. G. DA MADRE DE DeuS, Memórias cit., p. 143 (este autor afirma que em 19 de abril de 1561 já havia ali o pelourinho); M. E. DE AZEVEDO MARQUES, Apontamentos cit., t. I, p. 352.

${ }^{65}$ A. BARRETO DO AMARAL, Dicionário de história de São Paulo cit., p. 351.

${ }^{66}$ FR. G. DA MADRE DE DEUS, a partir do exame de dois documentos da época, um em que aponta que isso ocorreu entre 14 de agosto de 1546 e 3 de janeiro de 1547 (Memórias cit., p. 117). Ainda segundo Frei Gaspar, acompanhado por A. BARRETO DO AMARAL, a posse de Brás Cubas como Capitão-Mor da Capitania de São Vicente ocorreu em 8 de junho de 1545 (Dicionário da história de São Paulo cit., p. 122). Portanto, a data apontada por N. OdÁlia e J. R. DE CASTRO CAldEIRA (História do Estado de São Paulo cit., v. III, p. 260), 19 de janeiro de 1545, não concorda com essas fontes, pois é anterior à posse de Brás Cubas como Capitão-Mor e à escritura de venda de terras entre Pascoal Fernandes e Brás Cubas, em 14 de agosto de 1546, na qual há referência à Povoação de Santos.

67 Aprovado pelo Governador Geral do Brasil em 8 de fevereiro de 1552 (A. BARRETO DO AMARAL, Dicionário da história de São Paulo cit., p. 122).

${ }^{68}$ A. LeITE, História da civilização paulista cit., p. 24 e 26; M. B. NIZZA DA SILVA (org.), História de São Paulo colonial cit., p. 34. 
Em 1549, chegaram à Baía de Todos os Santos cinco jesuítas, sob as ordens de seu provincial, o padre Manuel da Nóbrega. Logo no ano seguinte, eles se transferiram para São Vicente, onde fundaram um colégio, com o objetivo de ensinar aos índios religião, leitura, escrita, aritmética, música etc. Porém, o Padre Nóbrega decidiu fundar um novo colégio no planalto de Piratininga por perceber que eles não chegariam verdadeiramente aos índios se ficassem restritos ao litoral ${ }^{69}$. O colégio de São Vicente, o segundo do Brasil, foi extinto em $1567^{70}$.

A povoação de Iguape já existia em 1537, provavelmente habitada por castelhanos sob o comando de Rui Moschera. Teriam ido para lá também degredados portugueses fugidos da Vila de São Vicente e índios Temiminés. Foi elevada a Vila sob o nome de Nossa Senhora das Neves de Iguape após a descoberta de ouro naquela região ${ }^{71}$.

Em 8 de abril de 1553, data em que o capitão Antônio de Oliveira, com toda a formalidade, levantou o pelourinho, foi fundada a Vila de Santo André da Borda do Campo. Porém, em 1560, por ordem de Mem de Sá, toda a população dessa Vila se transferiu para São Paulo de Piratininga. As atas da Câmara de Santo André, desde 22 de julho de 1555 até 31 de março de 1558, se conservam, e permitem vislumbrar como era o quotidiano dos moradores dessa primeira Vila do planalto paulista. Na última sessão da Câmara de que se tem registro, determina-se a reparação de muros e a construção de guaritas para defesa, ante a notícia de que haveria um ataque de índios ${ }^{72}$.

Em 25 de janeiro de 1554, os jesuítas, com a fundação de seu colégio, deram início à povoação ${ }^{73}$ de São Paulo de Piratininga ${ }^{74}$, para onde Tibiriçá, cacique dos

\footnotetext{
${ }^{69}$ A. DE SAINT Hildire, Viagem à província de São Paulo, Livraria Itatiaia e Editora da Universidade de São Paulo, São Paulo - Belo Horizonte, 1976, p. 21.

${ }^{70}$ A. LeITE, História da civilização paulista cit., p. 26. Segundo M. E. DE AZEVEDo MARQues, o Colégio de São Vicente foi fundado pelos padres Leonardo Nunes e Diogo Jacome, os quais foram mandados da Baía para São Vicente pelo padre Manuel da Nóbrega; outro dos fundadores seria Pedro Correia, que doou todos os seus bens para esse colégio e tornou-se jesuíta (Cf. Apontamentos cit., t. I, p. 185).

${ }^{71}$ M. E. DE AZEVEdo MARQues, Apontamentos cit., t. I, p. 321; N. OdÁliA e J. R. DE CASTRo CALDEIRA (org.), História do Estado de São Paulo cit., v. III, p. 151.

72 A. LEITE, História da civilização paulista cit., p. 28 e 32; M. B. NIZZA DA SILvA (org.), História de São Paulo colonial cit., p. 34-5.

${ }^{73}$ Segundo o diário de Pero Lopes de Sousa, Martim Afonso teria iniciado uma povoação a nove léguas pelo sertão, à beira do rio Piratininga. Também o Padre Manoel da Nóbrega, em carta a D. João III, em 1554, refere-se ao local chamado Piratinim como "onde Martim Afonso de Sousa primeiro povoou” (M. B. NIZZA DA SILVA (org.), História de São Paulo colonial cit., p. 32-3). É certo que Martim Afonso de Sousa esteve no Campo de Piratininga em 10 de outubro de 1532, pois ali assinou nesse dia uma doação de sesmaria a Pedro de Gois, documento esse lavrado pelo Escrivão de El-Rei Pedro Capico; porém, se ele, Martim Afonso de Sousa, iniciou nesse local alguma povoação, logo depois, ao retornar a São Vicente, se arrependeu, proibindo que os brancos, excetuado apenas João Ramalho, pudessem ir ao campo sem licença sua ou de seus locotenentes, "a qual se daria com muita circunspecção e unicamente a sujeitos bem morigerados". Essa proibição foi revogada por D. Ana Pimentel, mulher e procuradora de Martim Afonso de Sousa, por alvará
} 
Guaianazes, batizado com o nome de Martim Afonso, transferiu a sua aldeia inteira ${ }^{75}$. Essa povoação seria elevada a Vila em 5 de setembro de $1558^{76}$, ou 1560 , na ocasião em que Mem de Sá determinou a transferência do foral de Santo André para São Paulo. Na verdade, só a importância da Companhia de Jesus explica que a fundação de um colégio, e não a instalação do pelourinho e o início das atividades da Câmara, seja considerada a data da fundação de São Paulo ${ }^{77}$.

Em 1560 ou 1580, teve início uma aldeia de indígenas com o nome de Conceição dos Guarulhos, que em 1675 já era uma povoação, e em 1695 foi elevada a paróquia ${ }^{78}$.

Em 1561, Brás Cubas fundou uma fazenda que, com toda a probabilidade, daria origem à povoação de Sant'Ana das Cruzes de Mogi-Mirim, atual Mogi das Cruzes ${ }^{79}$, que foi elevada a Vila em $1611^{80}$.

Por volta de 1560, o Padre José de Anchieta (que só seria ordenado sacerdote em 1566) começou um aldeamento com indígenas Guaianazes, a que deu o nome de Ibirapuera. Ali João Paes e sua mulher Suzana Rodrigues erigiram uma capela em honra de Santo Amaro. Essa capela foi elevada a paróquia em 14 de janeiro de 1680. A elevação a Vila só ocorreu em 10 de julho de $1832^{81}$.

Nas imediações de São Paulo havia uma aldeia de índios Guaianazes, chamada Guarapiranga, da qual eles emigraram para as aldeias de Carapicuíba e Pinheiros ${ }^{82}$.

A aldeia de Carapicuíba, em 12 de outubro de 1580, foi concedida em sesmaria, com três léguas, aos índios oriundos de Piratininga. Para essa aldeia de Carapicuíba, que

\footnotetext{
lavrado em Lisboa, em 11 de fevereiro de 1544, e apresentado por Antônio Teixeira à Câmara de São Vicente em 3 de maio de 1544 (Fr. G. DA MADRE DE DEus, Memórias cit., p. 90-2).

${ }^{74} \mathrm{O}$ local para a fundação do colégio que daria origem à Vila foi escolhido pelo Padre Manoel da Nóbrega, entre os rios Anhangabaú e Tamanduateí. A primeira missa, no dia da Conversão de São Paulo, foi rezada pelo Padre Manoel de Paiva, com a presença dos Padres Gregório Serrão, Afonso Brás, Diogo Jácome, Leonardo do Vale, Gaspar Lourenço, Vicente Rodrigues, Brás Lourenço e Pedro Correia, dos irmãos José de Anchieta (hoje Beato) e Manoel Chaves, e dos leigos João Gonçalves e Antonio Blasques (A. BARRETO DO AMARAL, Dicionário de história de São Paulo cit., p. 577).

${ }^{75}$ A. DE SAINT HILAIRE, Viagem à província de São Paulo cit., p. 22.

${ }^{76}$ A. LEITE, História da civilização paulista cit., p. 31.

${ }_{77}^{7}$ M. B. Nizza dA Silva (org.), História de São Paulo colonial cit., p. 35.

${ }^{78}$ A. LeITE, História da civilização paulista cit., p. 32; M. E. DE AZEVEDO MARQUES, Apontamentos cit., t. I, p. 39.

${ }_{79}$ A. LeITE, História da civilização paulista, cit., p. 32.

${ }^{80}$ A. E. ZAluar, Peregrinação pela província de São Paulo, Edições Cultura, São Paulo, 2a ed., 1945, p. 129.

${ }^{81}$ M. E. DE AZEVEdo MARQUES; Apontamentos cit., t. II, p. 226-7.

${ }^{82}$ M. E. DE AZEVEDo MARQUES, Apontamentos cit., t. I, p. 306.
} 
foi uma das mais populosas, foram levados índios trazidos do sertão por Afonso Sardinha, cujo testamento foi escrito em 1604, pelo Padre João Álvares ${ }^{83}$.

Segundo a tradição, a aldeia de Pinheiros também foi criada pelo Padre José de Anchieta $^{84}$. Essa aldeia já existia em agosto de 1562, data em que é mencionada em uma petição do Padre Manoel da Nóbrega ao Capitão Pedro Colaço. Teria sido formada por índios que abandonaram Piratininga depois que esta foi ocupada pelos antigos habitantes de Santo André da Borda do Campo ${ }^{85}$.

A aldeia de Itaquaquecetuba, igualmente iniciada 1560 pelo Padre José de Anchieta, segundo a tradição, situava-se em terras do Padre João Álvares, em torno de uma capela em honra de Nossa Senhora da Ajuda, e era composta de índios Guaianazes emigrados das aldeias de Guarapiranga e Carapicuíba. Por volta de 1620, o Padre Francisco de Moraes, então ainda secular, foi buscar alguns índios nessa aldeia, para acompanharem o Governador Martim de Sá até a Ilha de Santa Catarina. Já em 1624, quando retornou, já religioso, o Padre Francisco de Moraes constatou que a maior parte desses índios havia mudado para a aldeia de São Miguel ${ }^{86}$.

Os índios de chefiados por Piquerobi também haviam recebido, em 12 de outubro de 1580, uma sesmaria de seis léguas, em Ururaí, no local que depois seria conhecido como São Miguel $^{87}$. Os jesuítas assumiram a direção desses índios em 1582. Para lá, por volta de 1623, emigraram índios da aldeia de Itaquaquecetuba. A capela de São Miguel foi construída por Fernão Munhoz e pelo Padre João Álvares ${ }^{88}$.

Em 1582, os jesuítas assumiram a direção de cerca de mil índios nas aldeias de Carapicuíba e Ururaî ${ }^{89}$.

Em 1585, foram fundadas as povoações de Aldeia Velha, a uma légua e pouco da futura São José dos Campos, e Itapecerica ${ }^{90}$.

Em 1592, a população da Capitania, entre brancos, índios e mamelucos, foi calculada em duas mil e quinhentas almas ${ }^{91}$.

\footnotetext{
${ }^{83}$ M. E. DE AZEVEdo MARQues, Apontamentos cit., t. I, p. 32-4 e 170; t. II, p. 343.

${ }^{84}$ M. E. DE AZEVEDo MARQUeS, Apontamentos cit., t. II, p. 171.

${ }^{85}$ A. Barreto do Amaral, Dicionário de história de São Paulo cit., p. 491.

${ }^{86}$ M. E. DE AZEVEdo MARQUES, Apontamentos cit., t. I, p. 76 e 356-7.

${ }^{87}$ M. E. DE AZEVEdo MARQUES, Apontamentos cit., t. II, p. 296 e 343.

${ }^{88}$ M. E. DE AZEVEdo MARQues, Apontamentos cit., t. I, p. 237; A. LeITE, História da civilização paulista cit., p. 39.

${ }^{89}$ A. LeITE, História da civilização paulista cit., p. 39.

${ }^{90}$ A. LEITE, História da civilização paulista cit., p. 40.

${ }^{91}$ A. LEITE, História da civilização paulista cit., p. 42.
} 
Entre 1562 e 1695, com apogeu entre 1628 e 1680, numerosas bandeiras paulistas fizeram o apresamento de índios. Em fins do século XVI tiveram início as bandeiras exploradoras de ouro ${ }^{92}$. Com a notícia da descoberta de ouro na selva, paulistas de todas as condições, que até então apenas se embrenhavam pelo sertão à procura de índios, mas sempre retornavam aos seus lares, passaram a acampar nas imediações das minas, dando origem a diversos povoados no interior, que muito ampliariam o território brasileiro. Sua terra natal, contudo, entrou em decadência após esse período ${ }^{93}$.

No início do século XVII, a Vila de São Paulo não contava mais que duzentos habitantes, uma centena de casas, uma igreja paroquial, um convento de beneditinos, outro de carmelitas, e o colégio de jesuítas. Ao final desse mesmo século, a população não passava de setecentos habitantes. Porém, as terras de seus arredores deviam ser muito povoadas, tanto que forneceram homens suficientes para a devastação do Paraguai e a exploração do centro do continente americano ${ }^{94}$.

Por provisão de 22 de março de 1681, a sede da Capitania de São Vicente é transferida para a Vila de São Paulo, dando-se a respectiva instalação em 27 de abril de $1683^{95}$.

Em 23 de novembro de 1709, D. João V criou a Capitania de São Paulo e Minas do Ouro, com território correspondente aos atuais Estados de São Paulo, Paraná, Minas Gerais, Mato Grosso, Mato Grosso do Sul, Santa Catarina, Rio Grande do Sul, até a Colônia do Sacramento. O governo dessa Capitania era totalmente separado do do Rio de Janeiro, sem outra subordinação a não ser ao governador e capitão-general da Bahia ${ }^{96}$.

Em 11 de julho de 1711, após a Coroa adquirir dos herdeiros dos donatários a Capitania, a Vila de São Paulo pôde ser elevada à condição de Cidade. Até então, só ostentavam esse título Salvador da Bahia, Rio de Janeiro, Olinda, Paraíba, São Luís e Cabo Frio. Com essa elevação, a Câmara passou a chamar-se Senado da Câmara ${ }^{97}$.

\footnotetext{
${ }^{92}$ A. Barreto do Amaral, Dicionário de história de São Paulo cit., p. 189-91.

${ }^{93}$ A. DE SAINT HILAIRE, Viagem à província de São Paulo cit., p. 28.

94 A. DE SAINT HILAIRE, Viagem à província de São Paulo cit., p. 124-5.

95 A. Barreto do Amaral, Dicionário de história de São Paulo cit., p. 154; A. Leite, História da civilização paulista cit., p. 62.

96 A. BARRETo Do Amaral, Dicionário de história de São Paulo cit., p. 156. Esse autor não menciona o Paraná, nem Mato Grosso do Sul. Acrescentamos, porém, no texto, esses estados, uma vez que a Província do Paraná foi desmembrada de São Paulo em 1853; e o Estado de Mato Grosso do Sul foi separado do de Mato Grosso em 1977.

${ }^{97}$ R. POMPEU DE TOLEDO, A capital da solidão, Objetiva, Rio, 2012, p. 202.
} 
Nas Capitanias, enquanto não fossem resgatadas pela Coroa, poderia haver apenas vilas. As cidades só poderiam ser assentadas em terras próprias alodiais ${ }^{98}$. A Capitania da Bahia de Todos os Santos foi concedida ao donatário Francisco Pereira Coutinho. Depois que este foi morto por índios Tupinambás, a Coroa adquiriu a Capitania de filho e sucessor, o que permitiu a instalação ali da primeira cidade do Brasil, Salvador, bem como da sede do Governo Geral. Os bispos não podiam residir em vilas, apenas em cidades, pois eram nobres de primeira grandeza e tinham o título de príncipes. Portanto, somente após a elevação de uma vila a cidade é que se admitia a instalação da respectiva diocese ${ }^{99}$.

Minas se desmembrou da Capitania de São Paulo, por alvará de D. João V, datado de 2 de dezembro de 1720. Santa Catarina e Rio de São Pedro (Rio Grande do Sul) se desmembraram da Capitania de São Paulo, por Provisão de D. João V, em 11 de agosto de 1738. Em dezembro de 1740, D. João V retirou da Capitania de São Paulo a Vila de Laguna, unindo-a à Capitania do Rio de Janeiro. Em 9 de maio de 1748, a rainha D. Maria Ana de Áustria, esposa de D. João V e regente do Reino durante a doença dele, criou o governo das Minas de Goiás e o das Minas de Cuiabá, bem como retirou o governo da Capitania de São Paulo, submetendo-a ao governador de Santos, subordinado ao Rio de Janeiro. Em 6 de janeiro de 1765, a Capitania de São Paulo foi restaurada por D. José I ${ }^{100}$.

Em 1745, foi criado o Bispado de São Paulo. O ato de criação foi assinado por D. João V em 22 de abril e confirmado pelo Papa Bento XIV em 6 de dezembro do mesmo ano. O primeiro bispo, D. Bernardo Rodrigues Nogueira, morreu em 7 de novembro de 1748 com fama de santidade ${ }^{101}$.

Conforme relatório do Padre José de Anchieta, em 1583, havia no Brasil quatorze mil africanos, dos quais dez mil estavam em Pernambuco, três mil na Bahia e mil no Rio de Janeiro. Portanto, ao menos até essa data, não havia africanos no território paulista. Outro relato, de 1610, do padre Jácomo Monteiro, também não menciona a existência de negros em São Paulo de Piratininga. Porém, em 1711, já havia negros em São Paulo em número suficiente para a formação da Irmandade de Nossa Senhora do Rosário dos Homens Pretos, cujo compromisso foi aprovado pelo Bispo do Rio de Janeiro nesse ano ${ }^{102}$.

\footnotetext{
${ }_{98}^{98}$ Isto é, livres de encargos (cf. DE PLÁCIDO E SILVA, Vocabulário jurídico, Forense, Rio, 28a ed., p. 97).

${ }^{99}$ M. FLEIUSS, História administrativa do Brasil cit., p. 11-13.

${ }^{100}$ A. Barreto Do AMARAL, Dicionário de história de São Paulo cit., p. 156.

${ }_{101}$ A. LEITE, História da civilização paulista cit., p. 89.

102 A. LEITE, História da civilização paulista cit., p. 39 e 47; M. B. NIZZA DA SILVA, História de São Paulo colonial cit., p. 84.
} 
Quanto à miscigenação, os jesuítas instituíram a política de casar indígenas com negros, de cujas uniões nasciam crianças que eram batizadas como "servos", ou seja, não eram nem administrados nem escravos, mas também não eram livres, servindo assim ao trabalho nas terras. Essa política foi seguida também pelos habitantes da Capitania ${ }^{103}$.

A. DE SAINT Hilaire, francês que permaneceu no Brasil entre 1816 e 1822 e viajou por grande parte do território brasileiro, tendo escrito uma importante obra sobre a Província de São Paulo, não encontrou registros sobre o aumento da população durante o século XVIII. Segundo esse autor, ao que parece, em 1807, a cidade de São Paulo e seu distrito, composto pelas freguesias de Santa Efigênia, Bom Jesus do Brás, Conceição dos Guarulhos, Nossa Senhora do Ó, Cotia, Nossa Senhora da Penha, São Bernardo e Juqueri, mais Santo Amaro e Parnaíba, não contava mais que vinte mil habitantes ${ }^{104}$.

\subsubsection{Paulistas e bandeirantes}

As bandeiras foram a grande epopeia paulista. Do palácio do Governador aos nomes de rodovias, avenidas, pontes, ruas, praças, monumentos, em praticamente todo o Estado há alguma lembrança dos bandeirantes ou de algum bandeirante em particular.

Ao saírem pelo sertão com a finalidade de caçar índios ou descobrir metais e pedras preciosas, desde meados do século XVI até o final do século XVII. Não temiam animais selvagens nem ataques de tribos indígenas. Alimentavam-se do que caçavam, pescavam ou encontravam pelo caminho. Ausentavam-se de sua terra por até vinte anos e, às vezes, nunca voltavam. Vestiam-se com roupas interiores de algodão, casacos de couro acolchoados de algodão, chapéus pardos e sapatos de couro de vaca ou veado. Cada qual levava um saco de couro contendo uma rede para dormir, travesseiro, cobertor e toalhas. Carregavam ainda armas e utensílios agrícolas. Frequentemente, gastavam tudo o que tinham para sair em uma dessas expedições ${ }^{105}$.

Esses paulistas avançaram muito além do Tratado de Tordesilhas, aumentando as posses da Coroa portuguesa. Foram eles os grandes responsáveis pela atual configuração do território brasileiro.

\footnotetext{
${ }^{103}$ M. B. NizZA DA SILVA, História de São Paulo colonial cit., p. 116.

${ }^{104}$ A. DE SAINT HilaIRE, Viagem à província de São Paulo cit., p. 125.

105 A Barreto do AmARAL, Dicionário da história de São Paulo cit., p.89 - 91.
} 
Graças a eles, o território da Capitania de São Vicente chegou a abranger o de diversos Estados da atual Federação que se desmembraram, tais como Rio Grande do Sul, Santa Catarina, Paraná, Mato Grosso, Mato Grosso do Sul, Goiás e Minas Gerais.

Bravura, intrepidez e desprendimento marcaram definitivamente o ideário do povo paulista. Ainda hoje se espera dos "magistrados bandeirantes" que se dirijam às suas comarcas, mesmo as mais distantes, com esse espírito e arrostem todas as dificuldades, dependendo minimamente dos recursos disponibilizados pela sede.

\subsection{ORGANIZAÇÃO E DISCIPLINA JUDICIÁRIA NO PERÍODO COLONIAL}

Conforme A. Wehling e M. J. Wehling, o estudo da justiça colonial no Brasil apresenta três grandes dificuldades: os anacronismos e incompreensões decorrentes da projeção, no plano institucional, de modelos político-administrativos posteriores à Revolução Francesa; os juízos negativos gerados pela aplicação de conceitos do liberalismo constitucional e do iluminismo, tais como liberdade, igualdade, Estado, sociedade etc., como se fossem universais e a-históricos; e a não consideração de que a justiça era uma "expressão da vida social e política permeada de religiosidade", na qual Deus era o juiz supremo, o rei, seu lugar-tenente, e a ordem jurídica, integrada aos princípios teológicos ${ }^{106}$.

Portanto, para compreender o funcionamento do aparelho judicial do Antigo Regime, é preciso fazer abstração dos conceitos de algumas categorias do direito constitucional contemporâneo, v. g., a divisão de poderes. Além disso, é necessário considerar que nesse período, não obstante a denominação "absolutismo", o poder real era limitado, na medida em que subsistiam outras esferas de poder: a aristocracia, o clero, os privilégios municipais e de corporações; e mais, concebia-se a harmonia social desejada por Deus por meio da justiça como a finalidade da lei positiva, o que restringia a atividade legislativa do monarca ${ }^{107}$.

\footnotetext{
${ }^{106}$ A. Wehling e M. J. WeHLING, Direito e justiça no Brasil colonial, Renovar, Rio, 2004, p. 25 - 28.

${ }^{107}$ A. Wehling e M. J. WeHLing, Direito e justiça cit., p. 29 - 36.
} 


\subsubsection{A justiça nos primeiros anos do descobrimento}

Nos trinta anos que se seguiram à descoberta do Brasil não houve qualquer preocupação de colonizá-lo imediatamente e, por conseguinte, de dotá-lo de autoridades judiciais. Por ocasião das poucas expedições exploratórias ou militares que houve nesse período, os respectivos chefes ou capitães arbitravam os conflitos surgidos entre a tripulação. Os litígios originados do comércio e navegação ultramarinos eram decididos pelo juiz da Guiné e da Índia, com recurso diretamente para a Casa da Suplicação. E, com relação aos poucos europeus que permaneciam por algum tempo no Brasil, a justiça era “dispensada pessoalmente, por estocada de espada ou tiro de mosquete"108.

Os primeiros atos para organizar a administração da justiça no Brasil foram três cartas régias, passadas em Castro Verde, aos 20 de novembro de 1530, em favor de Martim Afonso de Sousa. A primeira o autorizava a tomar posse das terras que descobrisse e a organizar nelas a administração civil e militar, prover os ofícios de justiça e tudo mais que fosse necessário ao governo delas e serviço público. A segunda lhe conferia os títulos de capitão-mor e governador, pelos quais todos deviam prestar-lhe obediência como à própria pessoa do rei, sob as penas que ele, Martim Afonso, impusesse. E a terceira lhe atribuía jurisdição e alçada civil e criminal, segundo as Ordenações Manuelinas, podendo impor até pena de morte natural, sem apelação nem agravo, salvo quanto aos fidalgos, os quais, se condenados, deveriam ser remetidos presos à Metrópole, juntamente com a nota de culpa. Caso se ausentasse, Martim Afonso deveria deixar um representante no Brasil ${ }^{109}$.

Portanto, a primeira autoridade judicial no Brasil foi Martim Afonso de Sousa.

Tanto essas cartas régias, como a fundação de São Vicente, em 22 de janeiro de 1532, são anteriores à divisão do Brasil em Capitanias Hereditárias.

\subsubsection{O Rei}

Principal órgão jurisdicional, o rei era também e consequentemente o principal responsável pela disciplina da Magistratura, cabendo-lhe aplicar os castigos que entendesse por bem nos casos mais graves, que deveriam ser levados ao seu conhecimento.

${ }^{108}$ S. B. SCHWARTZ, Burocracia e sociedade cit., p. 41-42 e 302.

${ }^{109}$ M. FleIUss, História administrativa do Brasil, Imprensa Nacional, Rio, 1923, p. 7. 
O poder real, além das limitações já mencionadas, a concepção de que ao rei cumpria fazer justiça em nome de Deus e a subsistência de outras esferas de poder, era também limitado pela importância atribuída à palavra dada do monarca e, consequentemente, ao juramento régio proferido no momento da aclamação, pelo qual ele se comprometia a "guardar as liberdades, franquias e isenções"110.

\subsubsection{A Casa da Suplicação}

Abaixo do rei, o órgão máximo do Poder Judiciário era a Casa da Suplicação de Lisboa, que julgava as causas de maior importância. Era presidida pelo regedor.

Para ocupar o cargo de regedor, as Ordenações Filipinas estabeleciam os seguintes requisitos: devia ser fidalgo; de "limpo sangue"; ter sã consciência; prudência; muita autoridade; ser letrado, se possível; íntegro, de tal forma que nem o amor, nem o ódio, nem qualquer outra perturbação de ânimo o impedisse de guardar justiça igualmente para com todos; abastado de riquezas, para que nenhuma necessidade particular pudesse perverter a sua integridade e constância em servir à Coroa; português nato; e, finalmente, ter capacidade de "temperar a severidade que seu cargo pede, com paciência e brandura" ao ouvir as partes, de modo que os homens de baixa condição e os miseráveis pudessem ser fácil e graciosamente acolhidos, não tivessem vergonha de lhe requerer justiça e suas causas não ficassem desamparadas, mas fossem despachadas bem e com brevidade ${ }^{111}$.

Vários desses requisitos para ocupar o mais alto cargo da magistratura portuguesa abaixo do rei, previstos há mais de quatro séculos, ainda hoje são válidos.

Das quatro virtudes cardeais, prudência, temperança, justiça e fortaleza, as três primeiras foram expressamente exigidas para ascender a esse cargo. E como "autoridade", segundo Bluteau, significa "força", também a "fortaleza" foi tacitamente mencionada entre esses requisitos $^{112}$.

Os requisitos da fidalguia e limpeza de sangue, hoje evidentemente inexigíveis, explicavam-se facilmente em uma sociedade hierárquica e católica, na qual esses elementos eram indissociáveis da respeitabilidade de uma pessoa.

\footnotetext{
${ }^{110}$ A. P. BARBAS HoMEM, Judex perfectus, Almedina, Coimbra, 2003, p. 160.

${ }^{111}$ Ordenações Filipinas, Livro I, título I.

${ }^{112}$ R. BLUTEAU, Vocabulario portuguez e latino cit, v. 1, p. 685.
} 
Enquanto a exigência de fidalguia dizia respeito ao nascimento ilustre, a de limpeza de sangue, tal como definida na Carta Régia de 13 de abril de 1633, que vedava aos cristãos-novos os cargos do Governo, da Fazenda e da Justiça, visava nomeadamente a impedir o crescimento do judaísmo e, segundo a mentalidade da época, a animar os recémconvertidos à perseverança na virtude e na religião cristã ${ }^{113}$.

Atualmente, as características imprescindíveis para que alguém seja respeitável em sociedade não são tão precisas, o que não quer dizer que não existam; por isso, a Constituição Federal em vigor, ao tratar dos requisitos para alguém ser ministro do Supremo Tribunal Federal, optou pela expressão "reputação ilibada".

Uma das principais atribuições do regedor era apurar faltas disciplinares na vida pública e privada dos desembargadores e demais oficiais da justiça, tais como: negligência ou descuido nos despachos; mau exemplo; ação contrária aos preceitos do cargo; recebimento de alguma dádiva; e cometimento de algum erro no exercício do cargo ${ }^{114}$.

Para essa apuração, eram previstas duas espécies de procedimentos disciplinares, um para os casos de desembargadores ou demais oficiais da administração da justiça negligentes, remissos em seus despachos, escandalosos às partes ou que não servem como deveriam servir; outro para os casos de corrupção e erro grave. O primeiro procedimento se desdobrava em três fases: inicialmente o regedor se valia de uma admoestação particular, que, se não resolvesse o problema, era seguida de uma admoestação na presença dos pares do culpado; e, se nem isso resolvesse, a acusação era levada ao soberano, que decidia qual o castigo merecido.

No segundo procedimento, reservado aos casos de corrupção ou erro grave, a acusação era desde logo levada ao soberano, que, apurada a verdade, aplicava o castigo que entendesse cabível.

A investigação não se restringia à vida pública do magistrado, mas estendia-se também à sua vida privada, a qual devia ser de modo a não causar escândalo.

\footnotetext{
${ }^{113}$ Carta Régia de 13 de abril de 1633, apud J. J. DE ANDRADE E SILVA, Collecção chronologica 1627 - 1633 cit., p. 309. Segundo C. Mendes de Almeida, a data dessa carta régia seria 13 de abril de 1636; porém, J. J. de Andrade e Silva, sustentando que a data correta seria 1633, remeteu os leitores que a buscam no volume quinto para o quarto volume de sua obra (Cf. C. MENDES DE AlmeIDA, Código Philipino cit., $1^{\circ}$ T., p. 1; J. J. DE ANDRADE E SILVA, Collecção Chronologica 1634 - 1640 cit., p. 77).

114 Ordenações Filipinas, Livro I, título I, § 45. "Remisso", expressão utilizada no texto legal, significa "descuidado"; "escandaloso", (ou "scandaloso", na grafia das Ordenações Filipinas) quer dizer "vir mali exempli"; dentre as várias acepções de "defeito", a compatível com a expressão "defeitos taes, por que seus officios não sejam servidos" é "contra os preceitos da arte" (cf. R. BLUTEAU, Vocabulario portuguez \& latino cit., v. 7, p. 237; v. 3, p. 207; e v. 3, p. 35).
} 
No primeiro procedimento, reservado às três primeiras faltas acima mencionadas, é claríssima a influência do texto bíblico relativo à correção fraterna ${ }^{115}$.

Assim, o regedor devia primeiro tentar corrigir o magistrado faltoso a sós, advertindo-o de sua falta. Se não houvesse emenda, deveria chamar outros de grau hierárquico correspondente ao do faltoso, que fariam as vezes das duas ou três testemunhas do texto evangélico. Se, apesar disso, ainda não houvesse emenda, o caso deveria ser submetido ao soberano, que fazia o paralelo com a autoridade da Igreja, o qual poderia darlhe o castigo devido, correspondente ao que, no âmbito eclesiástico, se equiparava a tratálo "como o gentio ou o publicano".

Porém, para as faltas cuja matéria estava compreendida no segundo procedimento não havia esperança de emenda. Uma vez apurada a verdade, cabia ao soberano a decisão sobre a imposição de pena.

Essas faltas são: "receber dádiva" e "fazer algum erro em seu ofício".

Quanto a receber dádiva, trata-se do que hoje chamamos corrupção. Os erros no ofício são aqueles que colidem com normas próprias das Ordenações.

Além da pena que o soberano aplicava discricionariamente nos casos de corrução ou erro no ofício, havia outras faltas para as quais havia pena específica, como a suspensão e multa, aplicadas cumulativamente, no caso de negativa de vigência às Ordenações. $O$ prazo da suspensão ficava a critério do monarca. E a mesma pena era aplicável aos desembargadores da Casa do Porto, corregedores, ouvidores e demais julgadores ${ }^{116}$.

As faltas disciplinares não possuíam tratamento sistemático nas Ordenações Filipinas, tanto que era previsto no mesmo dispositivo que a efetiva imposição dessas penas aos magistrados acarretava também consequências de ordem processual: a nulidade da decisão e a suspeição de seu prolator nos demais processos em que qualquer das partes estivesse em litígio.

\footnotetext{
115 "Se o teu irmão pecar, vai corrigi-lo a sós. Se ele te ouvir, ganhaste o teu irmão. Se não te ouvir, toma contigo mais uma ou duas pessoas, para que toda a questão seja decidida pela palavra de duas ou três testemunhas. Caso não lhes der ouvido, dize-o à Igreja. Se nem mesmo à Igreja der ouvido, trata-o como o gentio ou o publicano" (cf. Mateus, Cap. 18, 15-17).

116 "E mandamos, que todos nossos Desembargadores, que não cumprirem e guardarem nossas Ordenações inteiramente, sendo-lhes alegadas, paguem às partes, em cujo favor forem alegadas, vinte cruzados, e sejam suspensos de seus Officios até nossa mercê, e por esse mesmo feito ficarão suspeitos às ditas partes em os feitos, de que assim forem Juizes. E os desembargos e sentenças, em que assi não guardarem as ditas Ordenações, sejam nenhuns. E o mesmo o mandamos a todos os Desembargadores da Casa do Porto, Corregedores, Ouvidores e Julgadores, sob a mesma pena" (cf. Ordenações Filipinas, Livro I, título V, $\S 4^{\circ}$ ).
} 
A autoridade competente para impor essas penas era a que houvesse de julgar o recurso contra a decisão que descumpriu a Ordenação, conforme se depreende do número 6 do mesmo título. A duração da suspensão ficava a critério do soberano.

Para o caso de os feitos serem distribuídos a magistrados incompetentes, fossem eles desembargadores da Casa da Suplicação, da Casa do Porto, ouvidores, corregedores, juízes de fora ou juízes ordinários, as Ordenações Filipinas cominavam a pena de multa, correspondente ao dobro das custas pelo retardamento, se, instados pela parte, não remetessem os autos ao juízo competente no prazo de oito dias ${ }^{117}$. Trata-se, pois, do pagamento de indenização às partes pelo retardamento do feito provocado pelo fato de o magistrado reter em seu poder os autos de processo em que era incompetente.

Outra infração é a que atualmente é conhecida por antecipação de julgamento ${ }^{118}$.

Uma vez nomeado, o regedor deveria fazer jus à confiança nele depositada pelo soberano, os vícios contrários a essas virtudes estão compreendidos nas faltas disciplinares acima mencionadas. Porém, ao contrário da tendência atualmente demonstrada de "moldagem" do juiz a supostos valores, a tradição jurídica luso-brasileira, bem evidenciada pela norma acima mencionada, é no sentido de que a demonstração de virtudes para o exercício do cargo devia preceder a nomeação.

Os defeitos pelos quais "seus officios não sejam servidos como o devam ser" diziam respeito aos vícios que se opunham às virtudes esperadas do magistrado. Dentre eles, mereceu realce do legislador quinhentista o fato de os juízes "serem negligentes ou remissos em seus despachos", defeito grave, que atualmente se tem procurado enfrentar sob um prisma que não parece o mais adequado.

A corrupção é tradicionalmente prevista como crime pela nossa cultura jurídica.

\footnotetext{
117 "E mandamos a todos nossos Desembargadores, que não conheçam dos feitos que lhes claramente não pertencerem, e os remetam a seus Juizes competentes, tanto que requeridos forem per cada huma das partes, do dia, que pozerem nelle o primeiro desembargo, até oito dias primeiros, sob pena de pagarem às partes as custas em dobro de todo o retardamento, e dos autos, que perante esses Juizes incompetentes forem feitos, por quanto os havemos por nenhuns. E o mesmo cumprirão os Desembargadores da Casa do Porto, Corregedores, Ouvidores, Juizes de Fora, e Juizes Ordinarios da nossa cidade de Lisboa, sob a mesma pena" (cf. Ordenações Filipinas, Livro I, título V, $\S 8^{\circ}$ ).

118 "E os Desembargadores, que os ditos feitos despacharem, terão muito em segredo as tenções, antes de as sentenças serem publicadas, sem as praticar com pessoa alguma, postoque seja Desembargador da Casa, não sendo algum dos que no feito forem Juizes, porque com esses poderão praticar o que lhes parecer necessário para despacho do dito feito. E em quanto tiverem as tenções em suas casas, as terão fechadas de sua mão, de maneira, que as não possa ver pessoa alguma. E sendo negligentes no segredo, e cousas acima ditas, lhes será estranhado, segundo a qualidade da culpa, ou negligência, que nisso tiverem" (cf. Ordenações Filipinas, Livro I, título VI, § 17).
} 


\subsubsection{As Ouvidorias Gerais e Relações}

Até 1548, os Capitães Hereditários ou os ouvidores por eles nomeados eram os principais órgãos jurisdicionais instalados no território brasileiro. Nesse ano, porém, com a criação do Governo Geral do Brasil, foi criado também o cargo de Ouvidor Geral, com autoridade judicial sobre todas as Capitanias. Tratava-se de restringir os poderes dos Capitães, que eram uns quase-soberanos em suas donatarias ${ }^{119}$.

Ao ouvidor geral sucedeu o Tribunal da Relação da Bahia, chamado Relação do Brasil, criado em 7 de março de 1609, suprimido em 5 de abril de 1626 e restabelecido em 12 de setembro de 1652. Em 13 de outubro de 1751, foi criado o Tribunal da Relação de São Sebastião do Rio de Janeiro, cuja jurisdição compreendia a Comarca de São Paulo. Em 13 de maio de 1812 foi criada a Relação do Maranhão e, em 6 de fevereiro de 1821, a Relação de Pernambuco. Assim, por ocasião da Proclamação da Independência, eram esses os Tribunais existentes no Brasil ${ }^{120}$.

Do preâmbulo do Regimento dado por Dom Filipe à Relação da Bahia, em 7 de março de 1609, depreende-se que, até essa data, a mais alta autoridade judicial do Brasil era um Ouvidor Geral, o qual, dada a expansão dos descobrimentos, a conquista de novas terras, o aumento do comércio e das riquezas, não era suficiente para administrar a justiça como convinha. Assim, aquele Tribunal, com jurisdição sobre todo o território brasileiro, foi composto por dez membros: chanceler, três desembargadores de agravos, ouvidor geral, juiz dos feitos da Coroa, Fazenda e Fisco, procurador dos feitos da Coroa, Fazenda e Fisco e promotor de justiça, provedor dos defuntos e resíduos e dois desembargadores extravagantes.

A preocupação com o decoro da Corte aparece logo no início do Regimento, no qual se determina que a mesa grande seja coberta com pano de seda e sobre ela haja tinteiro, poeira e campainha de prata; as demais mesas deveriam ser cobertas com panos de lã e sobre elas campainhas, tinteiros e poeiras ordinárias. Também deveria haver escabelos de encosto, de couro estofado, todos da mesma altura, e cadeiras rasas. Quando despachavam na mesa grande com o governador, os desembargadores se sentavam nos escabelos de encosto mas, quando despachavam nas outras mesas, eles deveriam se sentar

${ }^{119}$ M. FLEIUSS, História administrativa do Brasil cit., p. 17-26.

${ }^{120}$ M. FLEIUSS, História administrativa do Brasil cit., p. 48-49. 
nas cadeiras rasas. Toda a despesa com a aquisição desses móveis e objetos foi feita a primeira vez pela Fazenda Real e daí em diante, pela própria Relação.

Logo em seguida, o Regimento trata da religião. Todos os dias o capelão da Relação deveria dizer missa, e só depois da missa os desembargadores começavam a despachar, por ao menos quatro horas, contadas no relógio de areia que ficava sobre a mesa do governador.

Os desembargadores não podiam entrar na Relação com armas, nem com roupas coloridas. Tanto na relação como na cidade, deveriam vestir opas como os desembargadores da Casa da Suplicação, "de maneira que representem os cargos que têm”.

Só não se exigia, como aos desembargadores da Relação do Porto, que deixassem crescer barbas longas, como as de senadores romanos ${ }^{121}$.

A seguir, o Regimento estabelece as funções do Governador do Estado do Brasil na Relação: não podia votar nem assinar sentenças; assinava somente perdões e alvarás de fiança, aplicando-se, no que fosse cabível, as disposições relativas ao Regedor da Casa da Suplicação. A cada três anos, o Governador deveria mandar um desembargador da Relação tomar residência aos Ouvidores das Capitanias, Capitães e pessoas que servissem em seu lugar.

Segundo R. BLUTEAU, a autoridade incumbida de "tomar residência" inquiria testemunhas para descobrir se aquele de quem a residência era tomada recebeu subornos ou dádivas, fez empréstimos, compras ou trocas com os litigantes, investigou os criminosos e os prendeu ou deixou de prendê-los, recebeu dinheiro das partes etc. A residência era tomada durante um mês, período em que aquele de quem é tomada devia se afastar por seis léguas do lugar em que exercia a jurisdição ${ }^{122}$.

O modo de tomar as residências era disciplinado pelo Livro I, título LX, das Ordenações Filipinas.

Se parecesse necessário ao Governador, ele deveria mandar um desembargador visitar as Capitanias, com os poderes de Corregedor. Os autos dessas residências seriam encaminhados à Relação e despachados em mesa grande. Achada culpa, o Promotor de Justiça procederia contra os culpados. Não achada, seria expedida uma certidão de que a autoridade servia bem, e com essa certidão ela poderia requerer o que de direito.

${ }^{121}$ S. B. SCHWARTZ, Burocracia e sociedade cit., p. 69-70.

${ }^{122}$ R. BLUTEAU, Vocabulario portuguez \& latino cit., v. 7, p. 282. 
Embora não tivesse propriamente funções jurisdicionais, na condição de Presidente do Tribunal da Relação, ao Governador-Geral competia impor penas disciplinares aos desembargadores. Isso aconteceu em 1615, quando os desembargadores Pero de Cascais e Antônio das Póvoas brigaram durante uma sessão e ambos foram suspensos pelo Governador-Geral ${ }^{123}$.

Uma vez por ano, o Governador deveria enviar ao Rei um rol com todos os feitos que foram despachados na Relação naquele ano e todos os que ficavam por despachar. S. B. SCHWARTZ, entretanto, põe em dúvida se esses róis - precursores das atuais planilhas chegaram a ser preparados; pois, se o foram, não se conservaram até hoje ${ }^{124}$.

As férias eram de dois meses, no período que o Governador entendesse necessário, conforme as ocupações e necessidades dos lavradores locais.

O Rei encomendava ao Governador muito cuidado para que os oficiais da Relação e seus criados não causassem dano, prejuízo ou opressão aos moradores da cidade de Salvador, nem de qualquer outro lugar em que fossem mandados, não lhes tomassem mantimentos contra suas vontades ou por preços abaixo de seu valor, nem lhes fizessem qualquer vexação. Deveria se informar a respeito todas as vezes que lhe parecesse necessário, e constatada alguma culpa, mandaria proceder como fosse de justiça.

Outro particular cuidado do Governador deveria ser o cumprimento da Lei sobre a liberdade dos índios. Sobre isso, houve efetivamente tentativa de exercício do poder disciplinar da Relação da Bahia com relação às autoridades judiciais paulistas, que eram negligentes na aplicação dessa lei, visto que a principal ocupação dos habitantes da Capitania de São Vicente era o aprisionamento de índios. Ao chegar a São Paulo, em fevereiro de 1614, o desembargador Manuel Jácome Bravo não foi bem recebido. O procurador da Câmara tentou dissuadi-lo a não continuar a investigação, pois, caso contrário, causaria a fuga dos moradores e o despovoamento da Vila. Além disso, flechas foram disparadas contra a janela do desembargador. Já na devassa seguinte, em 1619, presidida pelo desembargador Antão de Mesquita, a questão indígena não foi enfrentada diretamente: limitou-se ele a cominar prisão e multa para quem descumprisse a legislação, sem punir quem quer que fosse. Por essa razão, ele encontrou pouca resistência em sua $\operatorname{atividade}^{125}$.

${ }^{123}$ S. B. SCHWARTZ, Burocracia e sociedade cit., p. 166

${ }^{124}$ S. B. SCHWARTZ, Burocracia e sociedade cit., p. 131-132.

125 S. B. SCHWARTZ, Burocracia e sociedade cit., p. 143-144. 
Aos desembargadores e seus criados eram assegurados todos os privilégios dos desembargadores das Relações, conforme as Ordenações, e seus vencimentos correspondiam aos dos desembargadores da Relação da Casa do Porto.

A Relação tinha competência para julgar recursos cíveis nas causas cujo valor era de até dois mil cruzados em bens imóveis, ou três mil cruzados em bens móveis. Acima desses valores, cabia ainda recurso à Casa da Suplicação.

Para os casos em que as fianças se perdessem, o dinheiro deveria ser doado ao Hospital da Bahia de Todos os Santos.

Logo que instalada, embora bem recebida pela população, a Relação teve alguns conflitos com a jurisdição eclesiástica, por decidir questões que eram de competência da Igreja. A esse respeito, Frei Vicente do Salvador relatou episódio hilário, por ele presenciado: um homem que havia sido excomungado pelo bispo recorreu à Relação e seu recurso foi provido; contudo, mesmo após essa decisão, muitas pessoas passaram a evitálo, temerosos de incorrer na "excomunhão menor", pena canônica cominada aos que falavam com excomungados; diante disso, a Relação mandou publicar a cominação de pena de vinte cruzados aos habitantes de Salvador que deixassem de falar com o tal homem, "coisa que antes da excomunhão não faziam senão os que queriam"126.

Esse Regimento vigorou até o Alvará de 5 de abril de 1626, que extinguiu a Relação do Brasil, no contexto das invasões holandesas.

Diversos motivos contribuíram para a extinção da Relação: as altas despesas com a resistência às invasões holandesas fizeram surgir a necessidade de cortar gastos, tanto que as verbas destinadas aos salários do Tribunal foram expressamente destinadas à defesa territorial; a conjuntura histórica do período favorecia a tendência à valorização das armas em detrimento das letras; para a aristocracia local, não passava despercebido o papel da Relação no processo de centralização do poder real, o que aumentava sua insatisfação com esse órgão judiciário; o relacionamento do Tribunal com o bispo e o clero havia se deteriorado depois de vários conflitos; nas Capitanias, especialmente na de São Vicente e na do Rio de Janeiro, as visitas periódicas dos desembargadores haviam provocado hostilidades; em Pernambuco, a Capitania mais rica, havia também ressentimento contra a predominância política da Bahia, existindo vários indícios de que seu donatário, Matias de Albuquerque, tenha influenciado decisivamente a Coroa a extinguir o Tribunal ${ }^{127}$.

\footnotetext{
${ }^{126}$ Fr. V. DO SAlVADOR, História do Brasil cit., p. 300.

${ }^{127}$ S. B. SCHWARTZ, Burocracia e sociedade cit., p. 181-194 e 332.
} 
Conforme a Consulta de 14 de agosto de 1626, extrai-se que todos os desembargadores, exceto Antão de Mesquita, embarcaram para Portugal. Assim, não podendo esse único desembargador acumular todas as funções da Relação, foi ordenado que Diogo de São Miguel Garcez também ficasse no Brasil, e assim ambos ficaram responsáveis pela administração da Justiça a partir dai ${ }^{128}$.

Porém, em 12 de setembro de 1652, a Coroa novamente instituiu a Relação da Bahia e lhe deu novo regimento. No interregno entre a extinção do Tribunal e sua nova instalação, que ocorreu em março de 1653, houve a Restauração portuguesa, com a ascensão ao trono da Dinastia de Bragança; e a criação do Conselho Ultramarino, responsável por todos os assuntos civis e militares dos territórios de sua competência, salvo a nomeação de magistrados, que cabia ao Desembargo do Paço ${ }^{129}$.

Uma observação de S. B. SCHWARTZ sobre a Relação da Bahia no período subsequente à sua segunda instalação desmente a imagem comumente apresentada do Poder Judiciário brasileiro: os extremos da hierarquia social - brancos ricos e negros escravos - tinham facilidade em conseguir cartas de seguro para responder aos processos em liberdade. Quem tinha dificuldade em obter a soltura eram os brancos pobres, escravos libertos, artesãos e trabalhadores manuais, que não tinham dinheiro nem quem intercedesse por eles é que habitavam as cadeias de Salvador. Quando um escravo era preso, em geral o seu senhor pedia sua liberdade, alegando que necessitava dele para seu próprio sustento ${ }^{130}$.

A imagem desejável de um magistrado no período colonial pode ser extraída dos adjetivos utilizados nos relatórios do Governador à Coroa a respeito dos desembargadores da Relação da Bahia: “de bom entendimento", “de boas letras”, "sério, grave, capaz e prudente" e, sobretudo, o elogio da "limpeza de mãos", isto é, não corrompido ${ }^{131}$.

Para conseguir o acatamento das decisões judiciais, o Rei procurava elevar os desembargadores a uma posição privilegiada perante a sociedade. No contexto daquela época, um poderoso proprietário de terras com alguma nobreza não acataria facilmente uma decisão proferida por alguém de posição social inferior. Assim, caso o magistrado não tivesse origem fidalga para se fazer respeitar perante os potentados locais, era costume o Rei lhe conceder o hábito de alguma das Ordens Militares, especialmente a Ordem de Cristo. Nas procissões, nas quais compareciam de toga, os desembargadores tinham

\footnotetext{
128 J. J. DE ANDRADE E SILVA, Collecção Chronologica 1620 - 1627 cit., p. 163.

${ }^{129}$ S. B. SCHWARTZ, Burocracia e sociedade cit., p. $198-199$.

${ }^{130}$ S. B. SCHWARTZ, Burocracia e sociedade cit., p. 204.

${ }^{131}$ S. B. SCHWARTZ, Burocracia e sociedade cit., p. 148
} 
precedência logo após o Governador e o Bispo. Era-lhes assegurado lugar de honra em solenidades civis e religiosas. Suas pessoas eram invioláveis e quaisquer agressões físicas contra eles eram punidas com a morte; e as calúnias, com o degredo. Gozavam de algumas isenções de impostos e percebiam vencimentos elevados ${ }^{132}$.

A integridade pessoal era requisito indispensável ao acatamento das autoridades judiciais: um magistrado com alguma mácula em sua vida podia ser alvo de denúncia à Coroa em represália por alguma decisão, ainda que correta, que gerasse algum descontentamento. Foi o que aconteceu, por exemplo, com desembargador Pero de Cascais, que prendera dois arruaceiros por perturbação da ordem pública; entretanto, esses homens eram capangas do provedor-mor Sebastião Borges, o qual acusou o desembargador ao Rei por participação irregular na pescaria de baleias. O caso foi submetido ao Conselho da Fazenda, em Lisboa, e, ao final, os investimentos do desembargador nessa atividade foram considerados legais e ele não foi repreendido ${ }^{133}$.

Tentava-se assegurar a imparcialidade por uma série de normas que procuravam restringir a excessiva familiaridade dos magistrados com seus jurisdicionados. O Alvará de 22 de novembro de 1610 proibia "aos Desembargadores da Relação do Brazil casar-se n'aquelle Estado" 134 . Aliás, em relação aos corregedores, ouvidores, provedores e juízes de fora, já constava no Título XCV do Livro I das Ordenações Filipinas a proibição de se casarem com mulheres de sua jurisdição, durante o tempo de judicatura, sem licença do Rei. Não obstante, "pelo menos 17\% dos desembargadores que serviram no Brasil antes de 1759 casaram-se com brasileiras". Dos dez desembargadores que formavam a primeira composição da Relação do Brasil, dois se casaram com mulheres da aristocracia pernambucana $^{135}$.

Havia uma curiosa falta disciplinar - os desembargadores da Casa da Suplicação não podiam receber hóspedes em casa, salvo ascendentes, descendentes, irmãos, consanguíneos ou afins, amos, criados e outros desembargadores ${ }^{136}$ - certamente relacionada com a preocupação de que outras pessoas pudessem exercer alguma influência sobre a imparcialidade do magistrado. Isso fica claro pelas notas de C. MENDES DE ALMEIDA, que referem outras normas nesse sentido: a que proíbe que os desembargadores

\footnotetext{
${ }^{132}$ S. B. SCHWARTZ, Burocracia e sociedade cit., p. 149.

133 S. B. SCHWARTZ, Burocracia e sociedade cit., p. 156, 177-178.

134 J. J. DE ANDRADE E SILVA, Collecção chronologica da legislação portugeza 1603 - 1612, Lisboa, Imprensa de J. J. A Silva, 1854, p. 295.

135 S. B. SCHWARTZ, Burocracia e sociedade cit., p. 152.

136 Ordenações Filipinas, Livro I, título V, § 17.
} 
respondam cartas de pretendentes; e a que veda aos desembargadores que visitem pessoas que não sejam de sua classe ${ }^{137}$.

A preocupação de que os julgamentos fossem isentos já havia refletido na instituição de juízes de fora, que não teriam vínculos de parentesco ou amizade com qualquer das partes ${ }^{138}$.

Entretanto, nem todo o convívio social era vedado aos magistrados. Era comum que um desembargador, desde que nascido no Brasil ou casado com brasileira, se tornasse provedor da Irmandade da Misericórdia, responsável pela administração da Santa Casa. Além disso, era hábito que os desembargadores fossem convidados para padrinhos de batismo ou testemunhas de casamento de pessoas da sociedade local, o que, especialmente naquela época, criava vínculos assemelhados ao parentesco ${ }^{139}$.

Abusos de poder por parte das autoridades judiciais não eram tolerados e ensejavam punição. Em 1617, o chanceler da Relação da Bahia, desembargador Rui Mendes de Abreu, por conta de atraso no pagamento de seus vencimentos, mandou prender um funcionário do Tesouro. Como a Coroa já havia passado instruções anteriormente para que a Relação não interferisse em assuntos do Tesouro, o desembargador foi condenado a indenizar o funcionário preso ${ }^{140}$.

Outra espécie de abuso punível era a interferência na jurisdição eclesiástica. Quando o desembargador Francisco Mendes Marrecos retirou de um navio dois homens acusados de adultério que o bispo Dom Marcos Teixeira havia mandado deportar, o Rei, em 7 de maio de 1624, determinou a apuração dos fatos e que, se fosse constatada a culpa do desembargador, que ele fosse "logo reprehendido do excesso que cometeu"141.

Em 15 de julho de 1752, com Te Deum, touradas e cavalhadas, foi solenemente instalado o Tribunal da Relação do Rio de Janeiro, que passou a exercer jurisdição sobre o Rio de Janeiro, São Paulo, Minas Gerais e o sul do Brasil, até o Rio da Prata, em lugar da Relação da Bahia. O Tribunal ocupou a Casa da Câmara, único imóvel digno que havia na cidade, a qual se acomodou em imóveis alugados até a chegada de Dom João VI ao Brasil.

\footnotetext{
${ }^{137}$ C. Mendes de Almeida, Codigo Philippino cit., $1^{\circ}$ T. p. 20.

${ }^{138}$ I. M. POVEDA VELASCO, Os esponsais cit., p. 85.

${ }^{139}$ S. B. SCHWARTZ, Burocracia e sociedade cit., p. 151-154.

${ }^{140}$ S. B. SCHWARTZ, Burocracia e sociedade cit., p. 178-179.

141 J. J. DE ANDRADE E SILVA, Collecção Chronologica 1620 - 1627 cit., p. 121; S. B. SCHWARTZ, Burocracia e sociedade cit., p. 175.
} 
Foram providenciados móveis idênticos aos da Relação da Bahia, e uma capela com seus paramentos, que deveriam realçar a dignidade do Tribunal ${ }^{142}$.

A presidência do Tribunal foi ocupada pelo Governador da Capitania do Rio de Janeiro até 1763, e a partir daí pelo Vice-Rei do Brasil. Essa autoridade não tinha direito a voto nem assinava sentenças. Depois do Governador ou Vice-Rei, o cargo mais importante era o de Chanceler da Relação, cujas funções eram praticamente as mesmas do Chanceler da Relação da Bahia ${ }^{143}$.

Entre as funções do Governador ou Vice-Rei estava manter a disciplina dos membros do Tribunal. Em 1781, o Vice-Rei Luís de Vasconcelos mandou alguns presos, vigiados por militares, plantarem árvores e cercas vivas em um terreno para uso público. Entretanto, como alguns animais entravam nesse terreno e estragavam as árvores, o ViceRei autorizou os presos a tomar para si esses animais. No dia 31 de dezembro daquele ano, um carneiro do Desembargador Ambrósio Pitaluga foi capturado por um desses presos. Ao saber disso, o Desembargador foi até o local e já encontrou o carneiro morto. Furioso, o Desembargador começou a maltratar o preso e o ameaçou com um punhal, só não o atacando porque um padre o impediu. Além disso, o Desembargador ainda deu um empurrão no militar que vigiava esse preso. Ao saber disso, o Vice-Rei considerou o ato um desacato, mandou prender o Desembargador e o encaminhou a Lisboa. ${ }^{144}$

Esse Tribunal se mostrou cioso de suas prerrogativas: pouco tempo após a sua instalação, ele advertiu a Câmara de que não lançasse despachos no alto das petições, pois essa era uma prerrogativa dos oficiais reais e dos Tribunais. Quanto às demais autoridades, o despacho deveria ser dado ao pé da página. Os vereadores recorreram ao Conselho Ultramarino, que deu razão à Relação ${ }^{145}$.

Noutra oportunidade, o Guarda-Mor da Relação, Lourenço Dias de Campos, encaminhou duas representações a Lisboa, pedindo que, nas solenidades religiosas, tivesse o mesmo tratamento cerimonial que cabia ao Guarda-Mor da Casa da Suplicação. Na Relação da Bahia já era observada essa prática ${ }^{146}$.

O Tribunal também se mostrava zeloso quanto ao comportamento exigido dos magistrados de primeiro grau, tanto que certa vez fez constar em uma decisão: “antes da

\footnotetext{
${ }^{142}$ A. Wehling e M. J. Wehling, Direito e justiça cit., p. $121-130$.

${ }^{143}$ A. WeHLING e M. J. WeHLING, Direito e justiça cit., p. $146-148$.

${ }_{144}^{14}$ A. WeHLIng e M. J. WeHLING, Direito e justiça cit., p. $417-418$.

145 A. WeHLING e M. J. WeHLING, Direito e justiça cit., p. $140-141$.

${ }^{146}$ A. Wehling e M. J. Wehling, Direito e justiça cit., p. 140.
} 
sentença o juiz não devem declarar seus sentimentos sobre o mérito da causa", brocardo extraído do jurisconsulto Alvaro Valasco ${ }^{147}$.

1.2.5. Os Donatários e suas Ouvidorias, a Ouvidoria-Geral do Brasil e a Ouvidoria das Capitanias do Sul

Ao lado da justiça real, composta de órgãos ordinários e especializados, representada pelos Tribunais da Suplicação, da Relação, ouvidores, ouvidores gerais, ouvidores de comarca e juízes de fora, os quais, em regra, acumulavam diversas funções administrativas, houve também no Brasil a jurisdição concedida aos donatários das Capitanias Hereditárias, os quais poderiam exercê-la por si ou por ouvidores por eles nomeados, só abolida oficialmente na década de $1790^{148}$.

Premida pela necessidade de colonização, a Coroa, ao instituir as Capitanias Hereditárias, agiu em sentido inverso à tendência centralizadora que vinha então adotando a monarquia portuguesa. As cartas de doação de Capitanias costumavam atribuir toda a jurisdição ao donatário e seus sucessores, em cujas terras era proibida a entrada de corregedores ou quaisquer órgãos de justiça que nelas tentassem exercer qualquer jurisdição. Porém, com variações de Capitania para Capitania e de época para época, a política centralizadora acabou sendo adotada no Brasil à medida que a colonização $\operatorname{progredia}^{149}$.

Os ouvidores tinham, em princípio, as mesmas funções que as Ordenações Filipinas atribuíam aos corregedores. A diferença entre esses títulos está ligada à natureza do local em que exerciam suas funções. Normalmente, o ouvidor exercia suas funções em terras sob o controle de ordens militares ou grandes senhores, as quais estavam isentas de corregedores, isto é, da jurisdição real exercida diretamente ${ }^{150}$.

Em 2 de janeiro de 1608, tendo em vista a notícia de descobrimento de ouro, prata e outros metais nas Capitanias de São Vicente, Espírito Santo e Rio de Janeiro, o governo

\footnotetext{
147 A. Wehling e M. J. Wehling, Direito e justiça cit., p. 145.

${ }^{148}$ A. WeHling e M. J. WeHLING, Direito e justiça cit., p. 36 - 41.

${ }_{149}$ A. Wehling e M. J. Wehling, Direito e justiça cit., p. 41 - 42.

${ }^{150}$ S. B. SCHWARTZ, Burocracia e sociedade cit., p. 44.
} 
dessas três Capitanias foi desmembrado do governo geral do Brasil, e foi nomeado Capitão-Geral e Governador das Três Capitanias ${ }^{151}$.

Em 21 de março de 1630, o bacharel Paulo Pereira foi nomeado Ouvidor Geral das Capitanias do Rio de Janeiro, Espírito Santo e São Vicente e Distrito das Minas, cujo Regimento lhe outorgava poderes de Corregedor das Comarcas nessas localidades. Esse ouvidor geral das Capitanias do Sul conhecia das apelações contra as decisões dos ouvidores das Capitanias do Espírito Santo e de São Vicente e contra as decisões dos juízes ordinários de sua ouvidoria, ou seja, a do Rio de Janeiro. E contra as decisões dele, ouvidor geral, cabia apelação para a Casa da Suplicação ${ }^{152}$.

Ora, após a extinção da Relação da Bahia, em 14 de abril de 1628, uma Carta Régia nomeou Paulo Leitão de Abreu, até então Desembargador da Relação e Casa do Porto, como Ouvidor Geral das Partes do Brasil e promulgou o respectivo Regimento da Ouvidoria, o qual derrogou várias atribuições judiciais dos donatários das Capitanias e dos ouvidores por eles nomeados. No que diz respeito à matéria disciplinar, o item XII estabelecia que ouvidor geral, estando nas Capitanias, deveria se informar de como o donatário usava da jurisdição e administrava a justiça, sem sobre isso tirar inquirição ou fazer processo algum, mas devendo escrever ao rei o que apurasse. No item XIII, era determinado que o ouvidor geral se informasse se as Câmaras e oficiais delas guardavam as Ordenações e, com o parecer do governador geral, ele, ouvidor geral, poderia determinar o que bem lhe parecesse. O item XIV dava ao ouvidor geral, nas Capitanias, todos os poderes que as Ordenações Filipinas atribuem aos corregedores das Comarcas, desde que não contradissessem o Regimento. Em relação à disciplina do próprio ouvidor geral, o item XIX estabelecia que ele não poderia ser suspenso ou deposto do cargo pelo governador geral, dispositivo esse que colocava o ouvidor geral em situação de privilégio em relação aos antigos desembargadores, alguns dos quais chegaram efetivamente a ser suspensos pelo governador geral. Na hipótese de o ouvidor geral cometer algum crime ou excesso, devia o governador geral informar ao rei, para que este tomasse as providências cabíveis. $\mathrm{E}$ o item XXII proibia que o ouvidor geral se casasse ou tratasse casamento, sob pena de vacância imediata do cargo, independentemente de qualquer declaração ${ }^{153}$.

${ }^{151}$ J. J. DE ANDRADE E SILVA, Collecção Chronologica 1634 - 1640 cit., p. 245 - 250.

152 J. J. DE ANDRADE E SILVA, Collecção Chronologica 1627 - 1633 cit., p. 166-167.

153 J. J. DE ANDRADE E SILVA, Collecção Chronologica 1627 - 1633 cit., p. 124-127. 
Porém, alguns dias depois da acima mencionada nomeação do Ouvidor Geral das Capitanias do Sul, em 2 de abril de 1630, o bacharel Jorge da Silva Mascarenhas foi nomeado Ouvidor Geral das Partes do Brasil e Auditor da Gente de Guerra do Presídio. E seu Regimento, que manteve a mesma estrutura do Regimento dado ao Desembargador Paulo Leitão de Abreu, seu predecessor, não faz qualquer ressalva às Capitanias do Sul, dando a entender que também sobre elas se estenderia a jurisdição do novo Ouvidor Geral das Partes do Brasil ${ }^{154}$.

Merece realce nesse Regimento a determinação para que Jorge da Silva Mascarenhas residisse sempre em Salvador da Bahia de Todos os Santos, "cabeça do dito Estado do Brazil", de onde não poderia se ausentar, salvo se em outras Capitanias ocorressem crimes "tão atrozes" ou "excessos tocantes à Justiça” que fizessem necessária a sua presença em outro local, "para se remediarem”; nesses casos, só poderia se deslocar "com intervenção do Governador Geral", e detendo-se o menor tempo possível. Ora, no Regimento de Paulo Leitão de Abreu, a determinação era de que ele estivesse sempre no mesmo local em que o Governador Geral do Brasil.

Portanto, supostamente, a criação do cargo de Ouvidor Geral das Capitanias do Sul excluiria a jurisdição dessas Capitanias da Ouvidoria Geral das Partes do Brasil. Era, aliás, compreensível que estando o nordeste do Brasil no contexto das invasões holandesas, as Capitanias do Sul tivessem um judiciário próprio, subordinado imediatamente à Casa da Suplicação. Todavia, como o Regimento da Ouvidoria Geral do Brasil não fez qualquer ressalva a essas Capitanias, não é possível ter certeza a esse respeito, até porque, alguns anos depois, na Guerra entre os Pires e os Camargos na Vila de São Paulo, a autoridade invocada é o Governador Geral do Brasil, cuja sede era a Bahia.

\subsubsection{Os Juízes de Fora e os Juízes Ordinários}

As Vilas fundadas no século XVI (São Vicente, Santos, São Paulo etc.) se regiam pelas Ordenações Manuelinas. Assim, eram governadas pela Câmara, a qual, presidida pelo Juiz Ordinário, acumulava várias funções judiciárias ${ }^{155}$.

\footnotetext{
154 J. J. DE ANDRADE E SILVA, Collecção Chronologica 1627 - 1633 cit., p. 167-171.

${ }^{155}$ Ordenações Manuelinas, Livro I, Título XLIIII.
} 
Com a entrada em vigor das Ordenações Filipinas, no início do século XVII, o Juiz Ordinário e os vereadores, eleitos pelos "homens bons", tiveram a sua competência jurisdicional reduzida $^{156}$.

A Câmara de uma Vila, sob a égide das Ordenações Filipinas, compreendia um juiz ordinário, dois vereadores e um procurador do Concelho, assistidos de almotacel e alcaide $^{157}$.

O número de juízes ordinários, entretanto, podia variar. Em São Paulo, em geral havia dois; mas em 1563, apenas um; nos anos de 1575, 1603, 1623 e 1633, três; e em 1629, quatro. Em Santo André da Borda do Campo, em 1555, houve três ${ }^{158}$.

A magistratura no período colonial, conforme I. M. POVEDA VELASCO, estava organizada em dois níveis: a justiça ordinária e a justiça especial, cada qual com órgãos singulares e colegiados. À justiça ordinária de primeira instância pertenciam os magistrados inferiores, isto é, juízes ordinários e almotacés, ligados à vila ou cidade e eleitos; e os magistrados superiores, de nomeação régia ou do governo, que eram os juízes de fora, corregedores e ouvidores. A segunda instância da justiça ordinária era composta pelas Relações e Juntas de Justiça. À justiça especial pertenciam os juízes dos órfãos, provedores e juízes de comissão ou administração; e, em segunda instância, as Juntas da Justiça Militar, as Juntas da Fazenda e as Mesas de Inspeção. Além disso, havia a Casa da Suplicação em Lisboa ${ }^{159}$.

O juiz ordinário, eleito com mandato de um ano, tinha, juntamente com os homens bons, o "regimento" da cidade ou vila. Deveria comparecer sempre que possível à vereação da Câmara, para, com os homens bons, ordenarem juntos o que entendessem que é para o bem comum, direito e justiça. Se no local não houvesse juiz dos órfãos, o juiz ordinário acumulava essa competência. Devia fazer audiências uma ou duas vezes por semana, conforme o lugar tivesse até sessenta vizinhos ou mais que isso; e, se no local houvesse o costume de fazer mais audiências, esse costume deveria ser observado. Além disso, deveria fazer audiência aos presos. Podia ser que no lugar houvesse dois juízes ordinários, caso em que eles se revezariam a cada semana; se um dos dois ficasse doente, ausente ou impedido, por tempo não prolongado, somente um deles continuava no

\footnotetext{
${ }^{156}$ M. FLEIUSS, História administrativa do Brasil cit., p. 40-41.

157 A. DE EsCRAGNOLle TAUNAY, SãoPaulo cit., p. 32-36.

158 A. Wehling e M. J. WeHLING, Direito e justiça no Brasil colonial, Renovar, Rio, 2004, p. 52.

${ }^{159}$ I. M. POVEDA VELASCO, Os esponsais no direito luso-brasileiro, Quartier Latin, São Paulo, 2007, p. 84 88.
} 
exercício; se a ausência, impedimento ou doença se prolongasse, era feita nova eleição; e se os dois ficassem impedidos, ausentes ou doentes, assumiria o vereador mais velho em idade. Era obrigado a trazer consigo uma vara vermelha, insígnia de sua autoridade, e cada vez que fosse achado sem ela pagaria uma multa de quinhentos réis. Dependendo do número de vizinhos da localidade, do valor da causa e da matéria, suas sentenças poderiam ser irrecorríveis ${ }^{160}$.

O juiz de fora era nomeado pelo Rei para algumas localidades, sobrepondo-se ao Juiz Ordinário, tendo condição de julgar com maior imparcialidade, uma vez que não tinha laços de amizade ou parentesco com os da terra ${ }^{161}$. Era necessariamente jurista. Estava obrigado a usar continuamente uma vara branca, pagando multa de quinhentos réis cada vez que fosse achado sem ela. Conforme o valor da causa e a matéria, suas sentenças poderiam ser irrecorríveis ${ }^{162}$.

Infração disciplinar dos juízes ordinários e juízes de fora era não andarem continuamente com a vara de seu cargo, vermelha para os primeiros, branca para os segundos. A pena era de quinhentos réis para cada vez que fossem achados sem a respectiva insígnia ${ }^{163}$.

Se os juízes recebessem alguma quantia das partes, ainda que elas o quisessem dar, para as aconselharem, pagariam nove vezes a quantia recebida, metade para quem o acusou, a outra metade para a quem pagou, e ainda receberiam a pena que o Rei entendesse por bem ${ }^{164}$.

Receberiam castigo grave se consentissem que os arcebispos, bispos, vigários e prelados usurpassem a jurisdição da Coroa ${ }^{165}$.

Se não recolhessem os presos conduzidos de um Concelho para outro, a pena era de vinte cruzados, metade para quem o acusasse, outra metade para a Câmara do Rei, degredo para a África, mais o castigo que merecessem.

No episódio da Guerra entre os Pires e os Camargos, coube ao Conde de Atouguia, então Governador Geral do Brasil, a resolução do conflito.

Em 1641, com o assassinato de Pedro Taques, ligado à família dos Pires, por Fernão de Camargo, o "Tigre”, tem início a rivalidade entre as famílias Pires e Camargo,

\footnotetext{
${ }^{160}$ Ordenações Filipinas, Livro I, título LXV.

${ }^{161}$ I. M. POVEDA VELASCO, Os esponsais cit., p. 85.

162 Ordenações Filipinas, Livro I, título LXV.

${ }^{163}$ Ordenações Filipinas, Livro I, título LXV, $\S 1^{\circ}$.

${ }^{164}$ Idem, $\S 10^{\circ}$

${ }^{165}$ Idem, § 16.
} 
que deu origem a várias mortes ${ }^{166}$. No dia 8 de maio de 1653 , o Ouvidor Geral João Velho de Azevedo, que comparecera para "abrir os pelouros" e publicar a eleição dos novos oficiais da Câmara e Juízes Ordinários, encontrou a Câmara fechada, pois Fernando de Camargo, Juiz Ordinário, havia fugido e levado as chaves consigo. O Ouvidor Geral mandou arrombar a Câmara e o cofre dos pelouros, queimou os pelouros velhos e determinou que os vereadores do ano anterior continuassem em exercício até nova eleição. A partir daí há completo silêncio nas atas da Câmara até 5 de fevereiro de 1654, quando os vereadores se reúnem e decidem pedir auxílio ao Capitão-Mor, que reside em Santos, pois os irmãos José Ortiz de Camargo e Fernando de Camargo intentavam entrar na Vila com seus sequazes e armas. Em 7 de fevereiro de 1654, de fato, José Ortiz de Camargo, que entrara na Vila acompanhado de homens armados e provocando tumulto, apresentou à Câmara uma Provisão que o nomeava Ouvidor. Porém, a Câmara negou-lhe posse e mandou afixar editais a respeito. Em 9 de fevereiro de 1654, reúnem-se na Câmara os Vereadores, o Capitão-Mor, o Visitador dos Jesuítas, que era então Simão de Vasconcelos, o Abade do Mosteiro de São Bento, o Prior da Ordem do Carmo e o Guardião do Convento de São Francisco, que decidem dar posse a José Ortiz de Camargo, até a chegada do Ouvidor sindicante, desde que ele se comprometesse a não executar as ordens que trouxera da Bahia. Uma vez empossado, José Ortiz de Camargo não cumpriu o compromisso e praticou uma série de violências, até que, em $1^{\circ}$ de dezembro de 1654 , uma provisão régia anulou todos os atos por ele praticados. Pouco antes dessa Provisão, em 24 de novembro, o Governador Geral do Brasil, Conde de Atouguia, baixou um Alvará determinando que:

“(...) d'aqui em diante sirvam na Câmara da dita Villa tanto officiaes de um bando como de outro, para que com esta igualdade cessem as inquietações que de não a haver, se acenderam n'aquele povo, e a eleição se fará da maneira seguinte: chamará o ouvidor da Capitania com o escrivão d'aquella villa, na fórma da Ordenação, os homens bons e o novo d'ella ao conselho, e lhe requererá que nomeie cada um seis homens para eleitores, tres do bando dos Pires e tres do bando dos Camargos (não sendo os cabeças dos bandos, antes os mais zelosos e timoratos) e tanto que todos os votos fôrem tomados, escolherá para eleitores de cada bando os tres que mais votos tiverem. Estes seis fará apartar em tres pares, um Pires com um Camargo, e lhes ordenará , e lhes ordenará que façam os seus tres róes como é estylo, a saber: seis para juizes, tres de um bando e tres de outro, e um neutral, e tres para procurador do conselho, um Pires e um Camargo, e um neutral; e assim se usará para os mais officios, se os houverem na Camara, etc. (...)".

${ }^{166}$ A. LEITE, História da civilização paulista cit., p. 54. 
Seguia o Alvará concedendo perdão aos culpados, e quanto aos Camargos, que tinham sido sentenciados a pena capital, a execução da pena ficava suspensa, podendo todos ocupar livremente cargos públicos, sem qualquer impedimento. Tudo indicava que as hostilidades serenariam provisoriamente com essas disposições. Em 25 de janeiro de 1660, foi celebrado um tratado de paz entre as duas famílias, assinado por Fernão Dias Paes, representante dos Pires, e José Ortiz de Camargo, representante dos Camargos. A partir daí, as duas famílias se entrelaçaram por vários casamentos. Entretanto, em 23 de julho de 1674 e em 28 de dezembro de 1688, houve novas provisões, ratificando o perdão concedido aos culpados, o que indica que as discórdias entre essas duas famílias ressuscitavam de tempos em tempos ${ }^{167}$.

\subsubsection{Outros órgãos judiciais}

$\mathrm{Na}$ complexa estrutura judiciária colonial brasileira, conforme a importância da localidade, era possível a existência de outras autoridades judiciais.

Juiz de órfãos era obrigatório nas localidades com mais de quatrocentos vizinhos ou naquelas menos povoadas em que houvesse o costume de ter esse juiz. Se não houvesse juiz de órfãos na localidade, suas funções eram exercidas pelo juiz ordinário. Exigia-se idade mínima de trinta anos para ocupar esse cargo. Cumpria-lhe fazer os inventários e partilhas em que houvesse herdeiros órfãos menores de vinte e cinco anos, avaliar os bens do espólio nesses casos, zelar pelos bens desses órfãos. Se quem morresse fosse a mãe do menor de vinte e cinco anos, o administrador dos bens por ela deixados era o pai, mas o juiz de órfãos deveria obrigar o pai a fazer o inventário, mediante juramento sobre os Santos Evangelhos. Os pais deveriam entregar os bens aos filhos por ocasião da emancipação ou casamento. Julgava todos os feitos cíveis em que os órfãos fossem parte $^{168}$.

O almotacé fiscalizava o cumprimento das Posturas em relação aos carniceiros, padeiros, regateiras, almocreves, alfaiates, sapateiros e todos os outros oficiais; julgava sobre multas, chamadas coimas. De suas decisões cabia apelação ou agravo para o juiz

\footnotetext{
${ }^{167}$ M. E. DE AZEVEDO MARQUES, Apontamentos cit., t. II, p. 176-9; A. LeITE, História da civilização paulista cit., p. 54-8.

${ }^{168}$ Ordenações Filipinas, Livro I, título LXXXVIII.
} 
ordinário ou de fora. Conforme o valor, o juiz julgava esses recursos monocraticamente ou em Câmara, com os vereadores ${ }^{169}$.

O procurador do Concelho era o informante da Câmara, por quem ela tomava conhecimento dos acontecimentos notáveis, além de ser o advogado natural da edilidade, acompanhando os feitos, e era por seu intermédio que chegavam à Câmara as queixas e reclamações populares.

O alcaide pequeno era o chefe da polícia local, quem distribuía as guardas a cada noite e cumpria as ordens de prisão.

Instituído no Brasil em 1548, o cargo de provedor tinha, até 1613, atribuições meramente fiscais. A partir dessa data, passou a ser competente para a fazenda dos defuntos e ausentes e das capelas e resíduos ${ }^{170}$.

O corregedor da corte dos feitos crimes, nas cartas aos corregedores das comarcas, ouvidores, ou juízes, para o cumprimento de execuções ou diligências, deve fixar termo razoável para o cumprimento, sob a pena que entender adequada ${ }^{171}$. Idêntica providência deviam tomar os juízes dos feitos del rei da Coroa ${ }^{172}$; os juízes dos feitos del rei da Fazenda $^{173}$; e o promotor de justiça da Casa da Suplicação, que era um dos desembargadores $^{174}$.

As penas disciplinares dos juízes, alcaides, tabeliães e outros eram aplicadas pelos corregedores das comarcas ${ }^{175}$. O castigo, nesse caso, seria segundo o arbítrio do julgador, havendo respeito à culpa que teve no conluio, e à qualidade do caso e das pessoas.

Cabia ainda ao corregedor, que devia visitar uma vez ao ano os lugares sujeitos à sua correição, verificar se os juízes ordinários fizeram audiências nos processos de réus

\footnotetext{
${ }^{169}$ Ordenações Filipinas, Livro I, título LXVIII.

${ }^{170}$ I. M. POVEDA VELASCO, Os esponsais cit, p. 87.

171 "Outrossi, mandamos aos ditos Corregedores, que em todas as Cartas, que passarem, para se haverem de fazer algumas execuções, ou diligencias, seja posto termo razoado aos Corregedores das Comarcas, Ouvidores, ou Juizes, que as ditas execuções, ou diligencias houverem de fazer, que as façam no dito termo, e as enviem pelos Caminheiros, que lhes as Cartas presentarem, sob alguma razoadas pena, que lhes per eles Corregedores seja posta, segundo a qualidade do negocio, ou caso. A qual pena será para os ditos Caminheiros, se a eles demandarem; e não a demandando eles, seja para quem a demandar. As quaes Justiças mandamos, que cumpram em tudo o que pelos ditos Corregedores lhes for mandado, dentro no termo, que lhes for assinado, sob as penas postas pelos ditos Corregedores" (cf. Ordenações Filipinas, Livro I, título VII, $\S 23)$.

${ }^{172}$ Ordenações Filipinas, Livro I, título IX, § 18.

${ }^{173}$ Ordenações Filipinas, Livro I, título X, § 18.

${ }^{174}$ Ordenações Filipinas, Livro I, título XV, § $3^{\circ}$.

175 "E achando que os Juizes, ou outros alguns são culpados em esse conluio, por a sentença ser dada per peita, afeição, ou per outro modo maliciosamente, proceda contra eles, segundo a culpa de cada hum. E terá nisso a maneira, que diremos no Livro quinto, no Título 130: Quando o que foi livre per sentença de algum crime, etc." (cf. Ordenações Filipinas, Livro I, título LVIII, $\S 2^{\circ}$ ).
} 
presos, se desembargaram seus processos sem demora, se não deixaram de encaminhar os processos de reexame necessário, no casos em que era previsto e não houve recurso de qualquer das partes, se os juízes fiscalizam os tabeliães, se os juízes e vereadores eram culpados em relação às rendas do Concelho, se os feitos não eram julgados por culpa ou malícia dos juízes, se os juízes cumpriam e guardavam tudo que lhes era mandado.

Caso o corregedor da Comarca deixasse de cumprir com algum de seus deveres, era o rei quem lhe aplicava a pena que entendia merecer.

É importante observar que os forais das Capitanias geralmente continham isenção expressa das visitas de corregedores. Logo, as correições apenas poderiam ter lugar após o resgate de uma Capitania pela Coroa.

Importantíssimo papel teve no Brasil a Justiça Eclesiástica, que tinha jurisdição ratione personae, quando uma das partes do litígio era um clérigo, e ratione materiae, se o objeto do processo fosse da competência da Igreja, como, por exemplo, o casamento. O funcionamento da Justiça Eclesiástica era disciplinado pelas Constituições Primeiras do Arcebispado da Bahia ${ }^{176}$.

\subsection{O PERFIL DOS MAGISTRADOS}

O comportamento dos juízes era objeto de estudos da teologia moral ao longo do Antigo Regime. Martin de Azpicuelta Navarro escreveu um capítulo sobre os pecados do juiz no Manual dos confessores. O mesmo fizeram Frei João de Deus na Instrução para novos confessores, Sabelli na Summa diversorum tractatuum e Sammar na De officio judicis. Porém, uma descrição completa das qualidades que se exigem dos magistrados encontra-se na obra de Gabriel Alvarez de Velasco, Judex perfectus seu de judice perfecto Christo Jesu Domino Nostro unique perfecto, vivorum er mortuorum judici dicatus ${ }^{177}$

Para esse autor, a exemplo de Jesus Cristo, único juiz perfeito, o qual julgará os vivos e os mortos, o juiz perfeito deve ter as seguintes qualidades: forma virginale; aspectu vehementi et formidabili; luminibus oculorum acribus; nunque humilis neque atrocis; sed reverenda cujusdam tristitiae dignitate; gravem; sanctum; severum; incorruptum; inadulabilem; contraque improbos; nocetesque immisericordem; inexorabilem; erectum;

${ }^{176}$ A. Wehling e M. J. Wehling, Direito e justiça cit., p. 42.

${ }^{177}$ A. P. BARBAS HOMEM, Judex perfectus cit, p. 596 - 599. 
arduum; potentem vi et Majestate; Aequitatis, veritasque terrificum; librorum cumulo circunstante $^{178}$.

Na tradução de A. P. Barbas Homem ${ }^{179}$ :

"Beleza virginal; aspecto veemente e formidável; atento; nem humilde nem atroz; mas com a dignidade de uma certa austeridade; grave, santo; severo; incorrupto; não adulável; contra os ímprobos; impiedoso para os criminosos; inexorável; altivo; árduo; potente em força e em majestade; terrível na verdade e na equidade; estudioso".

Muitos discursos laudatórios de magistrados até hoje fazem alusão a várias dessas qualidades, o que mostra que o retrato de juiz perfeito traçado por Velasco repousa sobre traços permanentes da cultura luso-brasileira.

${ }^{178}$ Gabriel Alvarez de Velasco, Iudex perfectus seu de judice perfecto Chisto Jesu Domine Nostro.

${ }^{179}$ A. P. BARBAS HOMEM, Judex perfectus cit, p. 598. 


\section{O CONTROLE DISCIPLINAR DA MAGISTRATURA PAULISTA APÓS A PROCLAMAÇÃO DA INDEPENDÊNCIA DO BRASIL}

\subsection{NA CONSTITUIÇÃO IMPERIAL E NA LEGISLAÇÃO INFRACONSTITUCIONAL}

Em 7 de setembro de 1822, em São Paulo, na colina do Ipiranga, o Príncipe Regente D. Pedro I deu o célebre grito: Independência ou Morte. Na mesma noite, no modesto teatro da Ópera, localizado no Pátio do Colégio, em São Paulo, o Padre Ildefonso Xavier Ferreira o saudou como "primeiro rei brasileiro" 180.

Em 17 de março de 1823, por Decreto de D. Pedro I, a Cidade de São Paulo recebe o título de "Imperial"; e Itu, o de "Fidelíssima"181.

Em 11 de agosto de 1827 foi assinado o Decreto Imperial de fundação dos cursos jurídicos no Brasil, com a criação Faculdade de Direito de São Paulo, no Largo de São Francisco, e da Faculdade de Direito de Olinda.

A Constituição do Império do Brasil, de 25 de março de 1824, tratou do Poder Judicial do art. 151 ao art. 164.

Quanto aos predicamentos da Magistratura, o art. 151 da Constituição do Império afirmava a independência do Poder Judicial; que era reafirmada pelo art. 179, § 12, da mesma Constituição, o qual vedava expressamente a avocação e a sustação de causas pendentes, bem como a reabertura de processos findos.

Para o MARQUÊS DE SÃo ViCENTE, era preciso que até mesmo os mais altos servidores da Coroa, aqueles que poderiam aspirar à proteção dela, tivessem a convicção de que nem mesmo esse seu prestígio poderia fazer um juiz deixar de lado o seu dever de proferir uma sentença justa:

"A independência da autoridade judiciária do magistrado consiste na faculdade que ele tem, e que necessariamente deve ter de administrar a justiça, de aplicar a lei como ele exata e conscienciosamente a entende, sem outras vistas que não sejam a própria e imparcial justiça, a inspiração do seu dever sagrado. Sem o desejo de agradar ou desagradar, sem esperanças, sem temor algum"182.

\footnotetext{
${ }^{180}$ R. POMPEU DE TOLEDO, A capital da solidão cit., p. 294-5.

${ }^{181}$ A. LEITE, História da civilização paulista cit., p. 131.

${ }^{182}$ MARQUÊS DE SÃo VICENTE, Direito público brasileiro e análise da Constituição do Império, Editora 34, São Paulo, 2002, p. 407.
} 
Segundo J. C. RODRIGUES, a independência do poder judicial consiste na liberdade para o exercício das suas funções, não na sua separação dos outros poderes. E para que os juízes possam exercer suas funções livremente, é necessário que sejam inamovíveis ou perpétuos, e que seus vencimentos sejam suficientes à sua dignidade. Note-se que, para esse autor, perpetuidade e inamovibilidade são expressões equivalentes. Essa inamovibilidade, porém, de acordo com o art. 153 da Constituição Imperial, não significava que os juízes não pudessem ser mudados de um lugar para o outro na forma determinada pela lei. A forma das remoções era estabelecida pelo Decreto n. ${ }^{\circ}$ 559, de 28 de junho de 1850, e pelo Decreto n. ${ }^{\circ} 687$, de 26 de julho de $1850^{183}$.

De acordo com o Decreto n. ${ }^{\circ} 559$, de 28 de junho de 1850, os juízes nunca poderiam ser removidos para comarca de classe inferior, salvo requerimento seu; e para comarcas da mesma classe, a remoção somente poderia ocorrer em caso de rebelião, guerra, sedição, insurreição, conspiração ou representação da presidência da Província, neste caso com ouvida do Conselho de Estado.

$\mathrm{O}$ art. 153 da Constituição do Império estabelecia que os juízes de direito eram perpétuos, mas poderiam ser mudados de um lugar para o outro, na forma da lei.

A possibilidade de o imperador suspender os juízes de direito, em razão de queixas feitas contra eles, após audiência dos mesmos juízes, informações e ouvida do Conselho de Estado, era prevista no art. 154 da Constituição do Império. Decretada a suspensão, os autos e papéis concernentes à acusação deviam ser encaminhados à Relação respectiva, para a tramitação do respectivo processo, na forma da lei.

Logo, o Imperador podia decretar a suspensão provisória, mas a efetiva imposição de pena disciplinar era da competência do Tribunal a que o juiz estivesse subordinado. E mesmo a suspensão provisória dependia de procedimento, ainda que sumário. Porém, durante a Regência, em 12 de agosto de 1834, a Lei n. ${ }^{\circ}$ 16, conhecida por Ato Adicional, em seu art. $11,7^{\circ}$, conferiu às Assembleias Provinciais a atribuição de decretar a suspensão e mesmo a demissão de magistrado contra quem houver queixa de responsabilidade, após ser ele ouvido e garantindo-se-lhe a defesa.

A palavra "magistrado", empregada no Ato Adicional, foi objeto de esclarecimento pela Lei n. ${ }^{\circ} 105$, de 12 de maio de 1840 , pela qual se afirmou que nela não se compreendiam os membros das relações e tribunais superiores. Para esses, portanto,

183 J. C. Rodrigues, Constituição política do Império do Brasil, Eduardo \& Henrique Laemmert, Rio, 1863, p. $120-123$. 
continuava em vigor o art. 154 da Constituição Imperial, que reservava ao Imperador a prerrogativa de suspendê-los. Nessa Lei n. ${ }^{\circ}$ 105, constavam também os elementos do decreto de suspensão ou demissão do magistrado: 1) relatório do fato, 2) a citação da lei em que o magistrado estava incurso e 3) sucinta exposição dos fundamentos capitais da decisão tomada.

O Ato Adicional, de acordo com J. M. CORRÊA DE SÁ E BENEVIDES, não observou o regular procedimento para reforma constitucional, estabelecido pelo art. 176 da Constituição do Império: admitida pela Câmara dos Deputados a necessidade de reforma da Constituição, o Imperador, por meio de lei, devia ordenar aos eleitores dos deputados para a legislatura seguinte que lhes outorgassem procuração para alterar ou reformar o texto constitucional. Ainda segundo esse autor, o Ato Adicional transformou o Brasil em um "Império semi-federal"184.

Para W. MARTINS FERREIRA, as Províncias tiveram sua autonomia bastante aumentada pelos poderes que o Ato Adicional outorgou às Assembleias Provinciais, muitos dos quais, após a proclamação da República, compuseram a competência legislativa dos Estados ${ }^{185}$.

De acordo com o art. 155 da Constituição Imperial, os juízes só podiam perder o cargo em razão de sentença. Essa sentença deveria ser proferida em juízo contencioso ou, após o Ato Adicional, pela Assembleia Provincial, conforme os avisos de 16 de fevereiro de 1836 e 10 de fevereiro de $1837^{186}$.

No art. 156 da Constituição do Império era prevista a responsabilidade dos juízes de direito e oficiais de justiça por abusos de poder e prevaricações (Código Criminal, t. 5, cap. 1 de secc. $1^{\text {a a }} 6^{\text {a }}$; Código do Proc. Criminal, título 3, Cap. 5, Reg. 719, de 20 de outubro de 1850).

Estabelecia o art. 157 da Constituição do Império a ação popular contra juízes e oficiais por suborno, peita, peculato e concussão, no prazo de ano e dia, intentada por qualquer do povo (ato adicional art. 11, § $7^{\text {o }}$; Lei n. 105, de 12 de maio de 1840; Av. 373, de $1^{\circ}$ de dezembro de 1855; L. 261, de 3 de dezembro de 1841). Para o Marquês de São Vicente, o suborno, a peita, o peculato e a concussão:

\footnotetext{
${ }^{184}$ J. M. CORRÊA DE SÁ E BENEVIDES, Analyse da Constituição política do Império do Brazil, Typographia King, São Paulo, 1890, p. 136.

${ }^{185}$ W. MARTINS FerReIRA, História do direito constitucional brasileiro, Max Limonad, São Paulo, 1954, p. 55.

${ }^{186}$ J. C. Rodrigues, Constituição política do Império do Brasil cit., p. 124.
} 
"não são só crimes, mas crimes de um caráter tão vergonhoso, tão ofensivo da honradez de um julgador, que quebrantam a moral pública; é pois justo que qualquer do povo possa vindicar essa injúria feita à sociedade e à lei, promovendo por si mesmo a devida punição"187.

Segundo o art. 158, as Relações eram a segunda e última instância.

O Decreto n..$^{\circ} 1.482$, de 2 de dezembro de 1854, concedeu aos desembargadores o tratamento de senhoria.

Conforme a doutrina de J. C. RodRIGUES, é necessário que o Poder Judicial seja dividido em diferentes graus de jurisdição, não tanto para evitar a corrupção e a má-fé dos juízes, mas para evitar a precipitação dos julgamentos. Para esse autor, se a longa duração dos processos é um grave inconveniente, uma sentença precipitada e irrecorrível é um mal ainda maior:

“Concebe-se que n'um governo despotico as sentenças sejão pronunciadas com promptidão e celeridade e executadas da mesma maneira, pois nesta especie de governo, ou para melhor dizer, de desgoverno, quem decide é o capricho e a força, e não a justiça. Mas, em uma monarchia bem constituída, onde só deve reinar a justiça, cumpre que as sentenças sejão o resultado de uma convicção intima e illustrada, a qual é menos facil de se formar, do que é a arbitrariedade prompta em pronunciar" ${ }^{\text {"188 }}$.

Os arts. 163 e 164 da Constituição Imperial tratavam do Supremo Tribunal de Justiça, que foi criado pela Lei de 18 de setembro de 1828. De acordo com J. C. RODRIGUES, seria desejável que essa Corte fosse organizada de modo a conservar a uniformidade da jurisprudência; porém, salvo nos julgamentos de autoridades, esse órgão seria um "tribunal de aparato", porquanto sua competência estaria restrita a conceder ou denegar revistas e a conhecer e decidir sobre os conflitos de jurisdição e competência dos Tribunais das Relações. As autoridades cujo foro era o Supremo Tribunal de Justiça eram ministros, desembargadores das Relações, empregados do corpo diplomático, presidentes das Províncias. A Lei n. ${ }^{\circ}$ 609, de 18 de agosto de 1854, estendeu esse foro aos bispos e arcebispos do Império, nas causas que não forem puramente espirituais ${ }^{189}$.

A Lei de 22 de setembro de 1828 extinguiu o Tribunal da Mesa do Desembargo do Paço e o da Mesa da Consciência e Ordens.

\footnotetext{
${ }^{187}$ MARQUÊS DE SÃo VICENTE, Direito público brasileiro cit., p. 412.

${ }^{188}$ J. C. Rodrigues, Constituição política do Império do Brasil cit., p. 128-129.

${ }^{189}$ J. C. RODRIGUES, Constituição política do Império do Brasil cit., p. 132-133.
} 
A Lei de $1^{\circ}$ de outubro de 1828 deu nova forma às Câmara Municipais das cidades e vilas do Império. Até então, de acordo com o regime das Ordenações Filipinas, as Câmaras tinham o juiz ordinário, com jurisdição nas causas especificadas no capítulo anterior. Essa lei, em seu art. 24, proclamava que as Câmaras eram corporações meramente administrativas e não podiam exercer nenhuma jurisdição contenciosa.

O Decreto de $1^{\circ}$ de julho de 1830 , que em seu art. $2^{\circ}$ é talvez o mais antigo texto normativo que emprega a palavra magistrado como sinônimo de juiz, tratava do provimento dos Ofícios de Justiça vacantes ${ }^{190}$.

O Decreto de 3 de janeiro de 1833 estabelecia o Regimento das Relações do Império e foi modificado depois pelo Decreto de 23 de junho de 1834 . Já o Decreto n. ${ }^{\circ}$, de 17 de fevereiro de 1838 dispôs sobre as Relações.

Os juízes de direito foram criados pelo art. 44 do Código Criminal de 1830. Na parte cível, suas atribuições foram definidas pelos arts. 8 e 9 das Disposições Provisórias, e modificadas pelos arts. 24, 25, 119 e 121 da Lei de 3 de dezembro de 1841 (Código de Processo Criminal), e pelos arts. 3 e 36 do Regimento de 15 de março de $1842^{191}$.

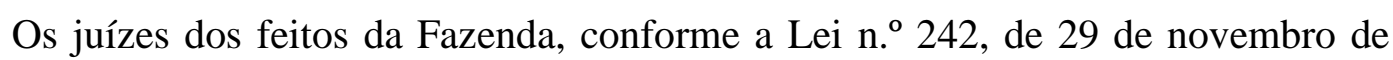
1841 e o Reg. de 12 de janeiro de 1842, nomeados pelo Imperador na Corte e Província do Rio de Janeiro, assim como nas Províncias da Bahia e Pernambuco. Nas demais províncias, servia o juiz de direito do cível da capital, ou, onde não o havia, o juiz de direito do crime que fosse designado, se houvesse mais de $\mathrm{um}^{192}$. A competência desses juízes consta no Aviso n. ${ }^{\circ}$ 6, de 12 de janeiro de 1842;

Os juízes Municipais eram previstos no art. 13 e seguintes da Lei n. ${ }^{\circ}$ 261, de 3 de dezembro de 1841 - Código de Processo Criminal e Decreto n. ${ }^{\circ}$ 143, de 15 de março de 1842 (execução da parte civil do Código de Processo Criminal).

$\mathrm{O}$ completo regramento da atividade jurisdicional aos poucos foi se delineando: $\mathrm{O}$ Decreto n. ${ }^{\circ} 559$, de 28 de junho de 1850, dispôs sobre a divisão das Comarcas, bem como sobre a remoção dos juízes de direito. O Decreto n. ${ }^{\circ}$ 687, de 26 de julho de 1850, instituiu regras para nomeações e remoções dos juízes de direito. O Decreto n. ${ }^{\circ} 834$, de 2 de outubro de 1851,regulamentou as correições. O Decreto n. ${ }^{\circ}$ 1.326, de 10 de fevereiro de 1854 ,

\footnotetext{
${ }^{190}$ M. GUIMARÃES, O juiz e a função jurisdicional, Forense, Rio, 1958, $1^{\text {a }}$ ed., p. 191.

191 J. I. Ramalho (BARÃo De Ramalho), Praxe brasileira, São Paulo, 1869, p. 32.

192 J. I. RAMALHO (BARÃO DE RAMALHO), Praxe brasileira cit., p. 34.
} 
dispôs sobre o vestuário usado pelos Juízes de Direito, Juízes Municipais e de Órfãos e Promotores Públicos no exercício das funções e solenidades públicas.

Em 11 de abril de 1836 e 10 de março de 1837, leis provinciais ordenam a realização de um “Quadro Estatístico da Província de São Paulo”, que será realizado por D. P. MÜLLER e publicado em 1838, com informações sobre a população, indústria agrícola, indústria manufatureira, indústria comercial, clima, finanças, estabelecimentos públicos e escolas, história civil e judicial, administração judicial e força armada. Já a essa altura, a Capital era a cidade mais populosa da Província ${ }^{193}$.

Em 1845, a Província de São Paulo, sob o aspecto jurisdicional, era dividida em sete Comarcas: $1^{\mathrm{a}}$ ) Taubaté, $2^{\mathrm{a}}$ ) São Paulo; $3^{\mathrm{a}}$ ) Campinas; $4^{\mathrm{a}}$ ) Itu; $5^{\mathrm{a}}$ ) Curitiba,; $6^{\mathrm{a}}$ ) Santos, e $7^{\text {a) }}$ Franca, que compreendia Moji-Mirim, Casa Branca, Franca e Batatais.

As seis primeiras Comarcas acima nomeadas foram criadas por leis gerais. Entretanto, o ato adicional de 12 de agosto de 1834 alterou a Constituição do Império para cometer às assembleias provinciais a criação de Comarcas. Assim, em 14 de março de 1839, foi criada a Comarca de Franca.

Em 17 de julho de 1852, uma lei provincial elevou o número de Comarcas a dez, suprimindo a de Santos. Assim, as comarcas da Província passaram a ser: $1^{\mathrm{a}}$ ) Guaratinguetá; $2^{\mathrm{a}}$ ) Taubaté; $3^{\mathrm{a}}$ ) Jacareí; 4 $4^{\mathrm{a}}$ ) Capital; 5 ) Campinas; 6 ) Mogi-Mirim; $7^{\mathrm{a}}$ ) Franca; $8^{\text {a }}$ ) Sorocaba; $9^{\text {a }}$ ) Itapetininga e $10^{\text {a }}$ ) Curitiba.

Em 29 de agosto de 1853, por lei geral, a Comarca de Curitiba foi elevada a Província do Paraná. A nova Província foi instalada em 19 de dezembro do mesmo ano, sendo o Conselheiro Zacharias de Góes e Vasconcelos o seu primeiro presidente.

Em 6 de maio de 1854, a Comarca de Santos foi restaurada por uma lei provincial.

Em 30 de março de 1858, o número de Comarcas foi elevado a treze: $1^{\text {a }}$ ) Bananal;

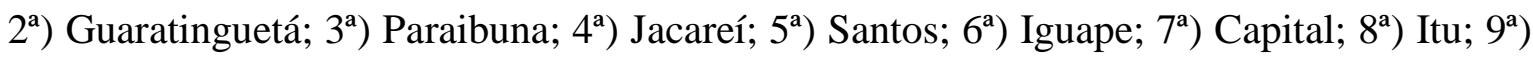

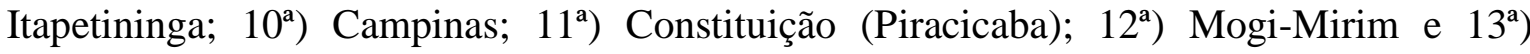
Franca.

Em 6 de maio de 1859, por lei provincial, foram criadas mais três Comarcas: São João do Rio Claro, Taubaté e Bragança.

\footnotetext{
${ }^{193}$ D. P. MÜLLER, Ensaio d'um quadro estatístico da Província de São Paulo ordenado pelas leis provinciais de 11 de abril de 1836 e 10 de março de 1837, Governo do Estado de São Paulo, São Paulo, $3^{\text {a }}$ ed. facsimilada, 1978, p. XI e XXV-XXX.
} 
Em 24 de fevereiro de 1863, uma lei provincial anexou a Vila de Limeira à Comarca de Rio Claro; a de Casa Branca à de Mogi-Mirim; e Serra Negra passou a fazer parte do Termo de Amparo, Comarca de Bragança.

Em 20 de abril de 1866, por lei provincial, o número de Comarcas foi elevado a dezenove: $1^{\mathrm{a}}$ ) Bananal; $2^{\mathrm{a}}$ ) Guaratinguetá; $3^{\mathrm{a}}$ ) Lorena; $4^{\mathrm{a}}$ ) Taubaté; $5^{\mathrm{a}}$ ) Paraibuna; $6^{\mathrm{a}}$ )

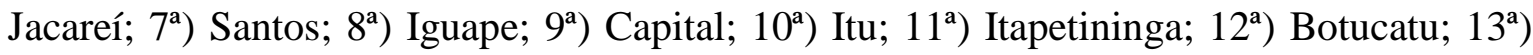

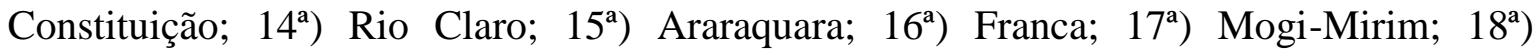
Campinas; $18^{\mathrm{a}}$ ) Bragança.

Em 1861, ao chegar à Capital da Província de São Paulo, A. E. Zaluar a chamou de "triste, monótona e quase desanimada"; afirmando que os estudantes de direito lhe imprimiam uma vida fictícia que, quando interrompida por suas férias, a fazia cair no "seu estado de habitual sonolência". Contava então a cidade com quarenta e seis mil habitantes ${ }^{194}$.

A Cidade de São Paulo, em 1872, quando foi realizado o primeiro censo por iniciativa do governo central, contava pouco mais de trinta e um mil habitantes ${ }^{195}$.

\subsection{A PRIMEIRA LEI SOBRE CONTROLE DISCIPLINAR}

A Lei n. ${ }^{\circ}$ 2.033, de 20 de setembro de 1871, sancionada pela Princesa Imperial Regente, que alterou diversos dispositivos da legislação judiciária, em seu art. 29, §§ 10 e 11, estabelecia que os juízes de direito, desembargadores e ministros do Supremo Tribunal de Justiça que se acharem física ou moralmente impossibilitados, serão aposentados, a seu pedido ou por iniciativa do Governo, com o ordenado inteiro, se contarem 30 anos de serviço efetivo, e com o ordenado proporcional, se tiverem mais de 10. Somente depois de intimado o magistrado para requerer a aposentadoria, e não o fazendo, ela terá lugar, precedendo consulta do Conselho de Estado, e procedendo-se previamente aos exames e diligências necessárias, com audiência do magistrado, por si ou por curador, no caso de impossibilidade.

$\mathrm{O}$ procedimento de verificação de incapacidade física ou moral foi fixado pelo Decreto n. ${ }^{\circ}$ 6.748, de 24 de novembro de 1877, baixado por D. Pedro II. Após a

\footnotetext{
${ }^{194}$ A. E. ZALUAR, Peregrinação pela província de São Paulo cit., p. 137.

${ }^{195}$ R. POMPEU DE TOLEDO, A capital da solidão cit., p. 365.
} 
proclamação da República, esse Decreto foi expressamente recepcionado no Estado de São Paulo, por meio da Lei n. ${ }^{\circ} 18$, de 21 de novembro de 1891, que organizou o Poder Judiciário paulista. Em seu art. 69, essa lei estabeleceu que, no julgamento de incapacidade física ou moral dos juízes, observar-se-á, no que for aplicável, o Decreto 6.748, de 24 de novembro de 1877 , que será adiante examinado.

\subsection{A instalaÇÃo do Tribunal da RElaÇÃo de SÃo PaUlo}

O Tribunal da Relação de São Paulo foi criado pelo Decreto Imperial n. ${ }^{\circ} 2.342$, de 6 de agosto de 1873, juntamente com outras sete Relações ${ }^{196}$. Ao tomar conhecimento desse decreto, o então Presidente da Província, Dr. João Teodoro Xavier, convidou a todas as "pessoas gradas" da capital para um solene Te Deum, no dia 11 de agosto daquele ano, ao meio dia, na Sé Catedral ${ }^{197}$.

A sua instalação ocorreu no dia 3 de fevereiro de 1874, na Imperial cidade de São Paulo, às onze horas, com a benção do edifício ${ }^{198}$ dada pelo vigário geral da diocese, Monsenhor Joaquim Manuel Gonçalves de Andrade, seguida das solenidades de praxe, inclusive o juramento, com a mão direita sobre nos Santos Evangelhos, com a fórmula "juro servir bem e fielmente o cargo de Desembargador, mantendo a Constituição e mais leis do Império, administrando justiça com boa e sã consciência. Assim Deus me ajude”. A instalação foi concluída com pomposo Te Deum, na Sé Catedral ${ }^{199}$.

\footnotetext{
${ }^{196}$ Havia no Brasil, até então, apenas quatro Relações: Rio de Janeiro, Salvador, São Luiz do Maranhão e Recife. O Decreto Imperial criou as de Belém, Fortaleza, São Paulo, Porto Alegre, Ouro Preto, Cuiabá e Goiás. Sob a jurisdição do Tribunal da Relação de São Paulo estava também a Província do Paraná. O então Ministro da Justiça, Conselheiro Manoel Antonio Duarte de Azevedo, que era Professor de Direito Romano na Faculdade de Direito do Largo São Francisco, teve grande importância para a criação do Tribunal da Relação paulista (F. TORRES, Tribunal de Justiça de São Paulo cit., p. 5 - 6).

${ }^{197}$ F. DE BARRos BROTERo, Tribunal de Relação e Tribunal de Justiça de São Paulo cit., p. 12. Esse convite para o Te Deum foi muito criticado pelo jornal Omnibus, em 16 de agosto de 1873, que atribuiu ao Sr. João Teodoro a "deplorável mania de fazer profundas inovações em tudo quanto há na província", acusando-o de falta de bom senso e de civilidade por mandar os convites apenas impressos, sem a assinatura de seu secretário, ou, ao menos, de seu oficial maior. Segundo esse jornal, se o convite não é portaria ou ordem, não tem força obrigatória, mas é dirigido a cidadãos que não exercem cargos públicos, "a delicadeza não tolera que se envie um impresso, sem que esteja revestido de assinatura" (F. TORRES, Tribunal de Justiça de São Paulo cit., p. 10).

${ }^{198}$ Era um velho casarão colonial, situado na Rua da Boa Vista, n. ${ }^{\text {2 }}$ 20, com fundos para a Rua Vinte e Cinco de Março, defronte a atual Rua Três de Dezembro (F. TORReS, Tribunal de Justiça de São Paulo cit., p. 5).

${ }^{199}$ F. DE BARros BROTERO, Tribunal de Relação e Tribunal de Justiça de São Paulo cit., p. 12-3.
} 
Estava-se, então, sob a égide da Constituição de 1824, que em seu art. 5\%, estabelecia que a religião Católica, Apostólica e Romana continuaria a ser a religião do Império, permitindo todas as outras religiões com seu culto doméstico, ou particular em casa para isso destinada, sem forma alguma exterior de templo. Deste modo, a grandiosidade de atos como a criação e a instalação de um Tribunal exigia o solene hino composto por Santo Ambrósio para agradecer a Deus por grandes benefícios.

\subsection{CONTURBADOS FATOS NO TRIBUNAL PAULISTA POR OCASIÃO DA} PROCLAMAÇÃO DA REPÚBLICA

Quando da Proclamação da República, constituiu-se em São Paulo um governo provisório, composto por Prudente de Morais, Coronel Joaquim de Sousa Mursa e Francisco Rangel Pestana, que, pelo Decreto n. ${ }^{\circ}$ 1, de 18 de novembro de 1889, em seu art. $4^{\mathrm{o}}$, dispôs que "as funções da justiça ordinária continuarão a ser exercidas pelos órgãos até aqui existentes, respeitados os direitos adquiridos pelos funcionários". Assim, o Tribunal da Relação continuou a funcionar normalmente, apesar da mudança do regime.

O Decreto n. ${ }^{\circ}$ 104, de 15 de dezembro de 1890, baixado por Jorge Tibiriçáa ${ }^{200}$, em seus arts. 47 e 48, previu a criação, pelo Congresso do Estado, de um Tribunal de Justiça, composto de nove juízes, nomeados pelo governador, dentre uma lista com os nomes dos magistrados mais antigos do Estado, em número igual ao quíntuplo das vagas a preencher. Todavia, esse decreto não chegou a ser executado. Em 14 de julho de 1891, foi promulgada a Constituição do Estado de São Paulo, que em seus arts. 44 e 45, dispôs que: "o Congresso criará um Tribunal de Justiça e os outros tribunais e juízes que entender necessários”; e que: "o tribunal de Justiça será composto de juízes, que o presidente do Estado nomeará de entre os magistrados mais antigos do Estado, apresentados em lista organizada pelo Tribunal, a qual conterá número igual ao décuplo das vagas a preencher". Já o art. $8^{\circ}$ das Disposições Transitórias dessa Constituição dispunha que: "nas primeiras nomeações de magistrados, quer para o Tribunal de Justiça, quer para os demais lugares que forem criados, o presidente do Estado preferirá, tanto quanto convenha aos interesses

\footnotetext{
${ }^{200}$ Nasceu em Paris, em 1855, e faleceu em São Paulo, em 1928. Foi nomeado governador do Estado de São Paulo, pelo Marechal Deodoro da Fonseca, e exerceu esse cargo de 18 de outubro de 1890 a 7 de março de 1891. Posteriormente, foi eleito presidente do Estado de São Paulo, exercendo o cargo de $1^{\circ}$ de maio de 1904 a $1^{\circ}$ de maio de 1908 (cf. A. Barreto do Amaral, Dicionário de história de São Paulo cit., p. 630-1).
} 
da melhor composição da magistratura, os desembargadores da atual Relação e mais juízes que funcionarem ou houverem funcionado no Estado. Parágrafo único. Para a primeira composição do Tribunal de Justiça o presidente do Estado nomeará nove juízes, observados os termos do art. $36^{\circ}{ }^{\circ}$ n. ${ }^{\circ}$ " (mediante aprovação do senado).

A instalação do tribunal, após a proclamação da República, sob a Constituição de 1891, cujo art. $72, \S 7^{\circ}$, assegurava que nenhum culto ou igreja gozaria de subvenção oficial, nem teria relações de dependência ou aliança com os governos da União e dos Estados, seria diferente da instalação do Tribunal da Relação. Assim, a ata da sessão solene de instalação do Tribunal de Justiça, em 8 de dezembro de 1891, não faz referência a qualquer cerimônia religiosa, nem à presença de qualquer autoridade eclesiástica. Essa sessão solene teve outras particularidades consentâneas com o novo regime: em vez do registro da presença de "pessoas gradas e numeroso concurso de cidadãos", registrou-se que o recinto do salão foi ocupado por "advogados e grande concurso de cidadãos"; o juramento foi substituído por uma "promessa de bem cumprir os deveres do cargo", e os desembargadores receberam o título de "ministros"201. É bem verdade que esse tribunal durou apenas uma semana, pois foi dissolvido em 16 de dezembro daquele ano, pelo Presidente do Estado, José Alves de Cerqueira Cesar.

Com a dissolução, voltou a funcionar o antigo Tribunal da Relação, até que foi novamente instalado o Tribunal de Justiça, no dia 13 de setembro de 1892. Na ata dessa instalação só há o registro da presença de autoridades, e o compromisso teve a seguinte fórmula: "prometo cumprir com retidão, amor à justiça e fidelidade à lei e às instituições vigentes, os deveres do cargo de ministro do Tribunal de Justiça"202.

Na década de 1890, a Cidade de São Paulo conhecerá um dramático crescimento populacional que, em termos relativos, será o maior de sua história. Em 1890, o recenseamento registra menos de sessenta e cinco mil pessoas; três anos depois, em 1893, a população já ultrapassava cento e trinta mil habitantes, ou seja, um crescimento de cem por cento; e, em 1900, a chegaria a quase duzentos e quarenta mil habitantes ${ }^{203}$.

\footnotetext{
${ }^{201}$ F. De BARros Brotero, Tribunal de Relação e Tribunal de Justiça de São Paulo cit., p. 182.

${ }^{202}$ F. DE BARros Brotero, Tribunal de Relação e Tribunal de Justiça de São Paulo cit., p. 186.

${ }^{203}$ R. POMPEU DE TOLEDO, A capital da solidão cit., p. 475.
} 

PAULO DURANTE A REPÚBLICA VELHA

Segundo J. BARBAlho de UchôA CAVAlCANTI, com o novo regime, o Poder Judiciário foi elevado a uma nova posição; enquanto antes se limitava a aplicar a lei, fosse qual fosse essa lei, aos casos controversos que lhe eram apresentados, passou a apreciar se a lei se insere dentro nos limites do poder que a decretou. "Antes julgava ele somente secundum legem, passou a julgar também de legibus, e eis tudo" 204.

Note-se que a Constituição de 1891, ao tratar do Poder Judiciário, só se refere ao Poder Judiciário da União, composto pelo Supremo Tribunal Federal e pelos juízes e tribunais federais.

“Art. 55: O poder judiciario da União terá por orgams um supremo tribunal federal, com sede na capital da Republica e tantos juizes e tribunais federaes, distribuidos pelo paiz, quantos o congresso crear."

São referências à Justiça Estadual:

O art. 59, I, “e”, que estabelece a competência do Supremo Tribunal Federal para julgar originária e privativamente:

"conflitos dos juizes e tribunaes federaes entre si, ou entre estes e os Estados, assim como os dos juizes e tribunaes de um Estado com os juizes e tribunaes de outro Estado".

Os $\S 1^{\circ}$ e $2^{\circ}$ do art. 59 :

“§ $1^{\circ}$. Das sentenças das justiças dos Estados em ultima instancia haverá recurso para o supremo tribunal federal: a) quando se questionar sobre a validade ou a aplicação de tratados e leis federaes, e a decisão do tribunal do Estado fôr contra ella; b) quando se contestar a validade de leis ou de actos dos governos dos Estados em face da Constituição, ou das leis federaes, e a decisão do tribunal do Estado considerar validos esses actos, ou essas leis impugnadas.

$\S 2^{\circ}$. Nos casos em que houver de aplicar leis dos Estados, a justiça federal consultará a jurisprudencia dos tribunaes locaes, e vice-versa, as justiças dos Estados consultarão a jurisprudencia dos tribunaes federaes, quando houverem de interpretar leis da União."

Depois de estabelecer a competência dos juízes e tribunais federais no art. 60, dispõe seu $\S 1^{\text {o: }}$ :

\footnotetext{
${ }^{204}$ J. BARBALHO UChÔA CAVAlCANTI, Constituição federal brasileira (1891) comentada, Companhia LithoTypographia, Rio, 1902, edição fac-similar do Senado Federal, p. 223.
} 
"§ $1^{\circ}$. É vedado ao congresso commetter qualquer jurisdicção federal às justiças dos Estados.

E a Seção III (Do Poder Judiciário) termina com os arts. 61 e 62:

“Art. 61: As decisões dos juízes ou tribunaes dos Estados, nas matérias de sua competencia, porão termo aos processos e às questões, salvo quanto

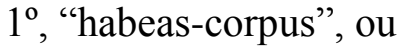

$2^{\circ}$, espolio de estrangeiro, quando a especie não estiver prevista em convenção, ou tratado.

Em taes casos, haverá recurso voluntario para o supremo tribunal federal.

Art. 62: As justiças dos Estados não podem intervir em questões submetidas aos tribunaes federaes, nem annullar, alterar ou suspender suas sentenças, ou ordens. E, reciprocamente, a justiça federal não póde intervir em questões submetidas aos tribunaes dos Estados, nem annullar, alterar ou suspender as decisões ou ordens destes, exceptuados os casos expressamente declarados nesta Constituição."

Merece realce, por fim, o art. 81, que, além das exceções do art. 61, estabelece a possibilidade de revisão dos processos criminais findos pelo Supremo Tribunal Federal. No dizer de J. BARBALHO UCHÔA CAVALCANTI:

"São duas exceções do princípio federativo, justificadas como expressão de grande desvelo e zelo pela liberdade individual, cujo goso pacifico e seguro é o escopo das constituições politicas" ${ }^{, 205}$.

Portanto, a autonomia e independência da Justiça dos Estados era solenemente proclamada pelo texto constitucional. Nas questões de sua competência ratione personae ou ratione materiae, em razão do princípio federativo, as Justiças Estaduais, salvo as raríssimas exceções acima mencionadas, não conheciam jurisdição superior ${ }^{206}$.

Mesmo quanto ao Tribunal do Júri, mantido pelo art. 72, § 31, da Constituição Federal de 1891, sua era competência definida por cada Estado de modo diverso. O Rio Grande do Sul e Mato Grosso entenderam dever manter a competência desse Tribunal tal qual era antes da República. Amazonas e Santa Catarina definiram que o Tribunal do Júri seria competente para os crimes mais graves. Noutros estados, coube a lei ordinária definir qual a competência do Júri, chegando algumas Constituições, como a dos Estados de Minas Gerais e Alagoas, a facultar sua instituição para julgar também matéria cível ${ }^{207}$.

\footnotetext{
205 J. BARBALHO UChÔA CAVALCANTI, Constituição cit., p. 349.

${ }^{206}$ J. BARBALHO UCHÔA CAVALCANTI, Constituição cit., p. 223.

207 CASTRO NunES, As constituições estaduaes do Brasil commentadas e comparadas entre si e com a constituição federal, t. I, Livraria Editora Leite Ribeiro, Rio, 1922, p. 152-3.
} 
Com a Emenda Constitucional de 1926, o Supremo Tribunal Federal tornou-se competente para julgar recursos "quando dois ou mais Tribunais locais interpretarem de modo diferente a mesma lei federal, podendo o recurso ser também interposto por qualquer dos Tribunais referidos ou pelo Procurador-Geral da República" (art. 60, § 1º “c”).

Em razão da autonomia de cada Estado, as variações entre eles no que toca à organização do Poder Judiciário são muitíssimas. A título de exemplo, embora só se considerassem magistrados os membros do tribunal e os juízes de direito, os quais gozavam das garantias de vitaliciedade e inamovibilidade, alguns estados criaram cargos de juízes municipais ou distritais, como Pernambuco, Espírito Santo e Paraná, que eram eleitos e tinham competência reduzida ou funcionando como juízes preparadores na esfera criminal, até a pronúncia ${ }^{208}$.

Logo, o estudo do Poder Judiciário estadual nesse período deve ser feito a partir da Constituição do Estado de São Paulo, que trata da matéria nos arts. 49 a 55.

\section{A Constituição do Estado de São Paulo durante a República Velha}

Proclamada a República, o Estado de São Paulo aprovou sua primeira Constituição em 14 de julho de 1891. Houve uma reforma constitucional, aprovada em 9 de julho de 1905. Uma segunda reforma, aprovada em 11 de julho de 1908, que fez apenas duas mudanças: elevou de doze para vinte anos o prazo para aposentadoria proporcional e eliminou as regras para aposentadoria compulsória dos magistrados com mais de 65 anos. Uma terceira reforma, em 8 de julho de 1911. E outra reforma de 9 de julho de $1921^{209}$.

A redação de 1891 garante à Magistratura "completa e segura independência". O princípio da vitaliciedade foi assim definido:

"O magistrado, depois de empossado, só por sentença criminal definitiva ou aposentadoria, na forma da lei, perderá o cargo."

Quanto aos crimes de responsabilidade, fixa a competência do senado para o processamento e julgamento dos membros do Tribunal de Justiça; e a competência do Tribunal de Justiça, com relação aos juízes. Porém, esse artigo contém um parágrafo único:

\footnotetext{
${ }^{208}$ CASTRO NunES, As constituições estaduaes cit., t. I, cit., p. 142-4.

${ }^{209}$ H. CoElho, A nova constituição do Estado de São Paulo de 9 de julho de 1921, Typographia do Diário Oficial, São Paulo, 1922, p. 7-10. Esse autor aponta para cada uma dessas datas uma nova Constituição. Porém, do exame do texto, que segue, inclusive, idêntica numeração dos artigos, muitos dos quais nunca foram alterados, conclui-se que a cada uma dessas datas corresponde, na atual nomenclatura técnica, uma reforma constitucional. E CASTRO NUNES (op. cit.) também fala em reforma.
} 
"A competência estatuída por este artigo prevalece quando se houver de julgar nos casos de incapacidade physica ou moral dos juizes".

$\mathrm{Na}$ redação de 1905, a incapacidade física ou moral foi expressamente mencionada como exceção ao princípio da vitaliciedade. E determinou que:

"A incapacidade physica ou moral dos magistrados será julgada pelo Tribunal de Justiça com a approvação do senado"

A reforma de 1911 substituiu a expressão incapacidade moral por incapacidade mental:

"O Tribunal de Justiça julgará da incapacidade physica ou mental de seus membros e dos juizes de direito, com a approvação do senado".

Por fim, na reforma de 1921, voltou-se à expressão incapacidade física ou moral:

Art. 52. Os membros do tribunal de justiça serão processados e julgados por este nos crimes comuns e pelo senado nos de responsabilidade. Os juizes de direito pelo tribunal de justiça.

$\S$ único. O tribunal de justiça julgará da incapacidade physica ou moral dos seus membros e dos juizes de direito, com a aprovação do senado.

Portanto, de 1891 até 1911, foi utilizada a expressão "incapacidade moral”. Com a reforma de 1911, usou-se a expressão “incapacidade mental”. E, a partir de 1921, voltou-se ao uso da expressão "incapacidade moral".

O senado mencionado nesses dispositivos é o estadual, previsto pelo art. 20 da mesma Constituição Estadual. Na redação de 1891, havia um senador para dois deputados. Com a reforma de 1905, o número de senadores foi fixado em vinte e quatro. Na reforma de 1921, o número de senadores era um para cento e quarenta mil habitantes ou fração superior à metade desse número, até o máximo de trinta.

Na redação de 1891, o mandato dos senadores era de seis anos, renovando-se pela metade, trienalmente. Na redação de 1905, o mandato foi estendido para nove anos, renovando-se pela terça, trienalmente.

Com relação ao sistema bicameral estadual, anota CASTRO NUNES que não era obrigatório, tanto que apenas sete estados o adotaram: Pará, Pernambuco, Alagoas, Bahia, São Paulo, Minas Gerais e Goiás. Os demais preferiram que o Poder Legislativo fosse exercido por uma única assembleia, denominada em geral "Assembleia Legislativa”, ou "Assembleia dos Representantes", no Rio Grande do Sul, ou ainda "Congresso 
Representativo", em Santa Catarina. O senado da União se justificava porque seus senadores representam os Estados. Mas, como os Estados não são uma "federação de municípios", para esse autor, esse senado estadual não tinha "qualquer significação política”. Nos Estados Unidos da América, porém, o sistema bicameral é adotado por todos os Estados-membros ${ }^{210}$.

Importa observar que, como observou JOÃO SAMPAIO nos debates que precederam a reforma constitucional de 1911, o senado apenas confirmava a declaração de incapacidade moral feita pelo Tribunal de Justiça. A intervenção do senado, no caso, era em favor do magistrado, pois visava a assegurar a justiça de seu afastamento do cargo ${ }^{211}$.

A expressão “incapacidade moral”, segundo CASTRO NUNES, indica o juiz "que se conduz mal", "que dá mostras públicas de incontinência", "que pode ser colhido nas malhas de um processo penal",212.

Já vimos que, entre 1911 e 1921, a redação da Constituição do Estado de São Paulo falava em incapacidade mental. Nos tramitação da reforma constitucional de 1911, a proposta de substituição do termo incapacidade moral por incapacidade mental foi impugnada por OSCAR DE ALMEIDA com as seguintes palavras:

"Quando o magistrado, pela sua conducta menos rigorosa ou menos austera, decahe do conceito publico, ou procede sem certo decoro, não havendo o caso de incapacidade physica, nem o da incapacidade mental, que são os que, após o referido julgamento, lhe determinam a perda do cargo, deixará de existir o remedio para afastar de suas altas funções o juiz que já não é mais digno de continuar a servir" 213 .

Respondeu então JoÃo SAMPAIO que a fórmula "incapacidade moral" é por demais ampla, sendo preferível "incapacidade mental", em atenção ao predicamento da vitaliciedade. Esclareceu que somente naqueles casos de incapacidade moral tipificados como delitos no Código Penal, entre eles o da notória incontinência, é que mereceria o magistrado a perda do cargo. E Mário Tavares, favorável à manutenção da denominação tradicional, incapacidade moral, replicou que a incapacidade moral prevista na Constituição não é apenas a que resulta da prática de crimes punidos na lei penal, pois esta desaparece com a reabilitação. E objetou ainda que toda incapacidade mental é física ${ }^{214}$.

\footnotetext{
${ }^{210}$ CASTRO NUNES, As constituições estaduaes cit., t. I, p. 59-61.

${ }^{211}$ H. COELho, A nova constituição do Estado cit., p. 652.

${ }^{212}$ CASTRO NunEs, As constituições estaduaes cit, t. I, p. 147.

${ }^{213}$ H. COELHO, A nova constituição do Estado cit., p. 654

${ }^{214}$ H. CoELHO, A nova constituição do Estado cit., p. 654.
} 
No entanto, prevaleceu a proposta de alteração, e durante dez anos não foi possível a perda do cargo por incapacidade moral.

Contudo, em 1921, a questão voltou à tona. Nos debates que precederam essa reforma, Joaquim Gomide reclamou que a supressão da incapacidade moral, em 1911, tornou letra morta o dispositivo, e reclamou que o termo fosse melhor explicitado ${ }^{215}$.

O reconhecimento da incapacidade moral do magistrado permitiaa que a garantia da vitaliciedade fosse afastada nos casos de irregularidade de conduta. As hipóteses de conduta irregular, segundo CASTRO NUNES, são aquelas que o art. 166 do então vigente Código Penal estabelecia para os demais empregados públicos: incontinência pública e escandalosa, vício de jogos proibidos, embriaguez repetida, inaptidão notória e desídia habitual. Segundo esse autor, se o Estado pudesse estabelecer outras hipóteses para a perda do cargo de juiz que não essas acima mencionadas, esvaziada estaria a garantia da vitaliciedade, a qual se converteria em estabilidade ${ }^{216}$.

Sob a vigência da República Velha, o Regimento do Tribunal de Justiça de São Paulo, em seu art. 27, inciso 17, alínea “c”, estabelecia que o Presidente do Tribunal podia impor aos juízes de direito multa, caso se ausentassem da respectiva Comarca sem licença ${ }^{217}$.

\subsection{Do golpe de Estado de Getúlio Vargas ao Regime Militar}

Com a Revolução de 1930, o então Chefe do Governo Provisório, por meio do Decreto n. ${ }^{\circ}$ 19.398, de 11 de novembro de 1930, arrogou-se o poder de nomear e demitir funcionários de quaisquer cargos públicos, inclusive os da magistratura (art. $8^{\circ}$ ).

Na Constituição de 1934, são referidos como órgãos do Poder Judiciário (art. 63) a Corte Suprema, os Juízes e Tribunais federais, os Juízes e Tribunais militares e os Juízes e Tribunais eleitorais. Nessa Constituição já são mencionadas as três garantias ainda hoje previstas: vitaliciedade, inamovibilidade e irredutibilidade de vencimentos. A organização do Poder Judiciário estadual continuava de competência dos Estados (art. $7^{\circ}$ ). Porém, ao

\footnotetext{
${ }^{215}$ H. COELHO, A nova constituição do Estado cit., p. 705.

${ }^{216}$ CASTRO NunES, As constituições estaduaes cit., t. I, p. 148-9.

${ }^{217}$ M. DA COSTA MANSO, O processo na segunda instância e suas aplicações à primeira, V. 1, Livraria Acadêmica - Saraiva \& Comp. Editores, São Paulo, 1923, 119.
} 
tratar da competência da Corte Suprema, essa Constituição já admitia o recurso extraordinário contra decisões das Justiças locais proferidas em única ou última instância (art. 76, III).

Pela primeira vez em um texto constitucional, a Corte Suprema foi proclamada competente para processar e julgar originariamente os membros das Cortes de Apelação dos Estados (art. 76, I, “b”).

Na Constituição de 1937, pela primeira vez, os Juízes e Tribunais dos Estados, do Distrito Federal e dos Territórios são mencionados dentre os órgãos do Poder Judiciário (art. 90). Logo, ainda que os Estados continuassem com competência para decretar suas próprias constituições e leis, a Constituição Federal passou a fixar princípios para organizar de forma mais centralizada a magistratura estadual (arts. 103 a 110).

A menção aos juízes e Tribunais dos Estados na Constituição Federal de 1937, até então alheia à tradição republicana, explica-se pela supressão da Justiça Federal. Logo, não mais coexistiam as Justiças Federal e Estaduais. A Justiça Estadual tornou-se competente para processar e julgar os feitos em que a União era parte, com recurso diretamente para o Supremo Tribunal Federal ${ }^{218}$.

O art. 91 repetia as três garantias da Constituição de 1934, porém diminuindo a idade da aposentadoria compulsória para 68 anos; e, quanto à inamovibilidade, tornou-se possível a remoção por interesse público, pelo voto de dois terços dos Juízes efetivos do Tribunal superior competente.

No art. 96 havia restrições aos tribunais para o reconhecimento da inconstitucionalidade de lei ou ato do Presidente da República. O art. 101, III, manteve, em sua substância, as hipóteses de recurso extraordinário da Constituição de 1934.

O art. 101, I, "b", fixou a competência originária do Supremo Tribunal Federal para processar e julgar os membros dos Tribunais de Apelação dos Estados.

$\mathrm{O}$ art. 105 criou o chamado "quinto constitucional”, com a integração de membros da advocacia e do Ministério Público aos órgãos colegiados judicantes, disposição mantida até a atualidade.

$\mathrm{O}$ art. 156, "c", tratava da exoneração de funcionários públicos em virtude de sentença judiciária ou processo administrativo em que sejam ouvidos e possam defenderse. Diferença entre exoneração e destituição. A "plena defesa", da Constituição de 1934,

\footnotetext{
${ }^{218}$ SEABRA FAGUNDES, A organização do funcionamento do poder judiciário; Estudos sobre a :Constituição brasileira, H. Lima (org.), Fundação Getúlio Vargas, Rio, 1954, p. 153.
} 
foi substituída por "sejam ouvidos e possam defender-se". Não há referência à possibilidade de recurso administrativo ${ }^{219}$. O art. 157 tratava da disponibilidade quando não cabia a exoneração.

De acordo com a Lei Constitucional n. ${ }^{\circ}$ 2, de 16 de maio de 1938, foi restabelecida, por tempo indeterminado, a faculdade concedida inicialmente por sessenta dias pelo art. 177 da Constituição, de o Chefe do Governo aposentar ou reformar civis e militares cujo afastamento se impusesse "segundo o interesse público ou a conveniência do regime". E pela Lei Constitucional n. ${ }^{\circ}$ 8, de 12 de outubro de 1942, "a expressão funcionário abrange os membros do Poder Judiciário, como servidores que são da Nação". Essa mesma Lei Constitucional n. ${ }^{\circ} 8$ estabeleceu que os juízes postos em disponibilidade ou aposentados no interesse do serviço público ou por conveniência do regime perceberão vencimentos proporcionais, a partir do ato da disponibilidade ou aposentadoria, salvo se contarem mais de trinta anos de serviço, hipótese em que receberão vencimentos integrais.

O Decreto-lei n. ${ }^{\circ}$ 1.202, de 8 de abril de 1939, regulamentou a administração dos Estados e Municípios, "até a outorga das respectivas constituições". Essa norma foi alterada pelo Decreto-lei n. ${ }^{\circ}$ 5.511, de 21 de maio de 1943.

Os poderes do Presidente da República foram delegados, no que couber, pelo Decreto-lei n. ${ }^{\circ} 5.511$, de 21 de janeiro de 1943, aos governadores dos Estados e prefeitos dos Municípios.

A Lei Constitucional n. ${ }^{\circ}$ 10, de 26 de maio de 1945, estabeleceu que os juízes, ainda que em disponibilidade, não podiam exercer qualquer outra função pública, salvo nos serviços eleitorais, sob pena de perda do cargo e de todas as vantagens correspondentes.

Pela Lei Constitucional n. ${ }^{\circ} 11$, de 30 de outubro de 1945, além dos serviços eleitorais, foi excepcionado o exercício de cargo em comissão e de confiança direta do presidente da República e dos interventores federais nos Estados.

Conforme o art. $5^{\circ}$ da Lei Constitucional n. ${ }^{\circ}$ 9, de 28 de fevereiro de 1945, a Lei Constitucional n. 2 deveria ter vigência até o dia em que se realizasse a eleição presidencial subsequente. Porém, com a assunção de José Linhares à Presidência, após a derrubada de Getúlio Vargas, o dispositivo foi definitivamente revogado pela Lei Constitucional n. ${ }^{\circ}$ 12, de 7 de novembro de 1945.

\footnotetext{
${ }^{219}$ P. F. BASTOS VON BRUCK LACERDA, Fundamentos do processo administrativo disciplinar, dissertação de mestrado, FDUSP, São Paulo, 2004, p. 80-1.
} 
Na Constituição de 1946, pela primeira vez, aparece a expressão "procedimento disciplinar". Fala-se nessa Constituição tanto em "plena defesa" como em "ampla defesa".

Ao disciplinar os órgãos do Poder Judiciário, em seu art. 94, a Constituição de 1946 não mencionou os juízes e Tribunais estaduais. A Justiça dos Estados é tratada no art. 124, reservando-se aos Estados a sua organização, de acordo com doze princípios. Entre eles: ingresso na magistratura vitalícia por concurso de provas e títulos; promoção dos juízes de entrância para entrância, por antiguidade e merecimento, alternadamente, sendo que a promoção por merecimento depende de lista tríplice organizada pelo próprio Tribunal de Justiça; quinto constitucional; competência privativa do Tribunal de Justiça para processar e julgar os juízes de instância inferior nos crimes comuns e de responsabilidade.

A competência originária para processar e julgar membros do Tribunal de Justiça dos Estados, nos crimes comuns e de responsabilidade, era do Supremo Tribunal Federal, conforme o art. 101, I, “c”.

Sob a égide dessa Constituição, o Tribunal de Justiça de São Paulo promulgou o Regimento de 1947, que em seu art. 108 estabelecia a competência do Conselho Superior da Magistratura para: I - exercer a inspeção suprema da Magistratura, cumprindo-lhe obstar que juízes de qualquer entrância e categoria: a) residam fora da sede da respectiva circunscrição judiciária; b) frequentemente se ausentem sem transmitir ao substituto legal o exercício do cargo; c) deixem de atender às partes a qualquer momento, quando se tratar de assunto urgente; d) excedam os prazos para decisão; e) demorem a execução de atos e diligências judiciais; f) maltratem as partes, testemunhas, funcionários e auxiliares da Justiça; g) deixem de presidir pessoalmente as audiências e os atos para os quais a lei exige a sua presença; g) deixem de exercer assídua fiscalização sobre seus subordinados, especialmente no que se refere à cobrança de custas e emolumentos, embora não haja reclamação das partes; i) frequentem lugares onde a sua presença possa diminuir a confiança pública na Justiça; j) cometam repetidos erros de ofício, denotando incapacidade, desídia ou pouco amor ao estudo; 1) pratiquem, no exercício das suas funções ou fora dele, faltas que prejudiquem a dignidade do cargo ${ }^{220}$.

Em 31 de março de 1964, um golpe de Estado instituiu o regime militar no Brasil. Seguiu-se uma série de Atos Institucionais. O preâmbulo do Ato Institucional n. ${ }^{\circ} 1$, de 9 de

\footnotetext{
${ }^{220}$ L. MALHEIROS e MOACYR DE SÁ, Regimentos internos do Tribunal de Justiça e do Tribunal de Alçada do Estado de São Paulo, RT, São Paulo.
} 
abril de 1964, expôs com clareza a doutrina jurídica que concede “à Revolução”, chamada de "forma mais expressiva e radical do poder constituinte", o poder absoluto na criação do direito. Aos revolucionários, segundo esse documento, cabia decidir manter ou não a Constituição anterior, manter ou não o Congresso, ao qual, se mantido, não caberia legitimar a Revolução, mas receber dela sua legitimação.

Com esse Ato Institucional n. ${ }^{\circ} 1$, foram suspensas por seis meses as garantias constitucionais ou legais da vitaliciedade e da estabilidade. Os titulares dessas garantias, mediante investigação sumária, poderiam ser demitidos, dispensados, postos em disponibilidade com vencimentos proporcionais, aposentados, transferidos para a reserva ou reformados pelo presidente da República ou, em se tratando de servidores estaduais, pelo governador do Estado, desde que tenham atentado contra a segurança do país, o regime democrático e a probidade da administração pública. Quanto aos servidores estaduais, cabia recurso ao presidente da República. O controle jurisdicional desses atos foi limitado ao exame das formalidades extrínsecas, vedada a apreciação dos fatos que os motivaram e o exame de conveniência e oportunidade. Os direitos políticos puderam ser suspensos e os mandatos legislativos federais, estaduais e municipais, cassados, no interesse da paz e da honra nacional, excluída a apreciação judicial desses atos.

Pela Emenda Constitucional n. ${ }^{\circ}$ 14, de 3 de junho de 1965, a Justiça Eleitoral passou a ter competência para processar e julgar juízes em crimes eleitorais.

O preâmbulo do Ato Institucional n..$^{\circ}$, de 27 de outubro de 1965, apresentou a teoria de que "o processo revolucionário tem de ser dinâmico para atingir os seus objetivos". Portanto, a autolimitação a que a Revolução se impôs, no Ato Institucional n. ${ }^{\circ}$ 1, não significa que ela "tenha se despojado da carga de poder que lhe é inerente como movimento". Logo, em seu art. 14 e parágrafo único, esse Ato Institucional suspendeu as garantias constitucionais da vitaliciedade, inamovibilidade e estabilidade, permitindo que os titulares dessas garantias pudessem ser demitidos, removidos, transferidos, aposentados e reformados por "incompatibilidade com os objetivos da Revolução".

A Emenda Constitucional n. ${ }^{\circ}$ 16, de 26 de novembro de 1965, permitiu a remoção ou disponibilidade de juiz de instância inferior, pelo voto de dois terços dos membros efetivos do Tribunal competente, por "motivo de interesse público". Somente para a disponibilidade era assegurada a defesa. 
Na Constituição de 24 de janeiro de 1967, o capítulo VIII, tratava do Poder Judiciário. O art. 107 enumerava os órgãos do "Poder Judiciário da União". O art. 136 tratava da Justiça dos Estados, determinando a aplicabilidade dos arts. 108 a 112.

$\mathrm{O}$ art. 108 tratava das garantias da vitaliciedade, inamovibilidade, com ressalva do interesse público reconhecido por dois terços dos juízes efetivos do Tribunal, em votação secreta, assegurada a defesa, e irredutibilidade de vencimentos.

O art. 109 dispunha das vedações, sob pena de perda do cargo, de exercer, ainda que em disponibilidade, qualquer outra função pública, salvo um cargo de magistério e outros casos previstos na própria Constituição; percebimento de percentagens, a qualquer título e sob qualquer pretexto, nos processo sujeitos a seu despacho e julgamento; e exercício de atividade político-partidária.

$\mathrm{O}$ art. 136, IV, ao tratar do quinto constitucional, exigiu "notório merecimento e idoneidade moral". E seu $\S 3^{\circ}$ fixou a competência do Tribunal de Justiça para processar e julgar os membros do Tribunal de Alçada e juízes de instância inferior. A competência para julgar os membros dos Tribunais de Justiça dos Estados, de acordo com o art. 114, I, “b”, era do Supremo Tribunal Federal.

De acordo com o Ato Institucional n. ${ }^{\circ}$, de 13 de dezembro de 1968, em seu art. $6^{\circ}$, foram suspensas as garantias constitucionais da vitaliciedade, inamovibilidade etc. Acrescentava o $\S 1^{\circ}$ que o presidente da República, por decreto, poderia demitir, remover, aposentar ou por em disponibilidade quaisquer titulares dessas garantias. E, conforme o $\S$ $2^{\circ}$, essas disposições eram aplicáveis também nos Estados, Municípios, Distrito Federal e Territórios.

Durante o regime militar, os magistrados paulistas Edgard de Moura Bittencourt, Dácio Aranha de Arruda Campos e José Francisco Ferreira foram afastados compulsoriamente da magistratura e tiveram seus direitos políticos cassados. Dácio Aranha de Arruda Campos era comunista confesso. José Francisco Ferreira chegou a ser preso, por ter hasteado a bandeira a meio pau no dia $1^{\circ}$ de abril de 1964, no Fórum de Pacaembu, em protesto contra o golpe militar. ${ }^{221}$

\footnotetext{
${ }^{221}$ R. A. Mesquita DE Oliveira (realização), 60 anos: o ideal que nos fez Apamagis, Rosa de Ouro Comunicação, São Paulo, 2013, $1^{\text {a }}$ ed., p. 6.
} 
O Regimento Interno do Tribunal de Justiça de São Paulo vigente durante o regime militar, no que diz respeito às faltas disciplinares dos juízes, em seu art. 113, repetia ipsis litteris o art. 108 do Regimento de 1947, acima transcrito ${ }^{222}$.

${ }^{222}$ A. MACEDO DE CAMPOS (anotador e atualizador), Regimento interno do Tribunal de Justiça do Estado de São Paulo, Jalovi, Bauru, $1^{\text {a }}$ ed., 1978, p. $59-60$. 


\section{O CONTROLE DISCIPLINAR DA MAGISTRATURA PAULISTA EM NOSSOS DIAS}

\subsection{O PODER-DEVER DE PUNIR INFRAÇÕES NA DOUTRINA}

Os membros do Poder Judiciário, não obstante sua tradicional denominação de agentes políticos, como todos aqueles que servem ao Estado, estão sujeitos a uma série de deveres, tanto na vida pública como na particular, cuja infração acarreta sanções específicas. O estudo desses deveres e dessas sanções é objeto do direito administrativo disciplinar.

Na definição de E. MAIA LuZ, "direito administrativo disciplinar é "o ramo do direito administrativo destinado a apurar, decidir e regular, por todos os aspectos pertinentes, as relações que o Estado mantém com os seus servidores, visando ao respeito das leis e das normas que regulam as atividades funcionais". 223

A Questão 67 da Segunda Seção da Segunda Parte da Suma Teológica de S. TOMÁs DE AqUINO tem o seguinte título é de iniustitia iudicis in iudicando. ${ }^{224}$

Para o Doutor Angélico, são atos injustos dos juízes: 1. julgar quem não lhe esteja sujeito (iudicare eum qui non est sibi subiectus); 2. julgar segundo seu próprio arbítrio (secundum proprium arbitrium), e não de acordo com as proposições e provas apresentadas no processo (secundum ea quae proponuntur et probantur) ${ }^{225}$; 3. julgar alguém mesmo que não haja acusador ${ }^{226}$ (aliquem iudicare etiam si non sit alius accusator); e 4. absolver de pena ao réu culpado (poenam relaxare).

É importante notar que S. TOMÁs DE AQUINO distingue, para efeito da quarta das possíveis injustiças cometidas pelos juízes, os juízes inferiores do príncipe, este investido de plenos poderes (princeps, qui habet plenariam postestatem in republica). Provada a acusação, um juiz está interdito de absolver da pena o réu, por dois motivos: o primeiro, da parte do acusador - no caso, a vítima, que tem o direito de exigir a punição do réu; o

\footnotetext{
${ }^{223}$ E. MAIA LuZ, Direito administrativo disciplinar cit., p. 64.

${ }^{224}$ S. TOMÁS DE AQUino, Suma teológica, v. VI, Loyola, São Paulo, 2005, p. 170-8.

225 Nas Ordenações Filipinas, Livro III, título 63, é expressamente previsto, para os processos cíveis, o julgamento por verdade sabida.

${ }^{226}$ II Seção da II Parte, Q. 67, art. 4. O argumento de S. Tomás é tirado de S. Ambrósio, segundo o qual, embora Judas fosse ladrão, o Senhor não o repeliu, porque ele não foi acusado.
} 
segundo, da parte do Estado, em nome do qual se exerce a justiça, e cujo bem exige que os malfeitores sejam punidos (ad cuius bonum pertinet quod malefactores puniantur). Porém, quanto ao príncipe, desde que a vítima queira perdoar a injustiça (si ille qui passus est iniuriam velit eam remittere), e desde que veja que a absolvição não seria nociva ao interesse público (si hoc publicae utilitati viderit non esse nocivum), pode licitamente absolver o réu (poterit reum licite absolvere) ${ }^{227}$.

Tal distinção ainda hoje é contemplada na Constituição Federal, que atribuiu ao exclusivamente ao Presidente da República conceder clemência.

Dessa distinção do Doutor Angélico se depreende que o soberano apenas poderia absolver um magistrado cuja culpa fosse provada se houvesse o perdão da vítima e se isso não se mostrasse contrário ao interesse público.

Como a palavra "poder" tem conotação de faculdade, possibilidade, a doutrina cunhou a expressão "poder-dever" para designar os poderes da Administração, uma vez que os agentes públicos estão obrigados a exercer a competência que a lei lhes atribui, a tomar todas as providências e a utilizar todos os meios disponíveis para a realização do interesse público, sob as penas do crime de prevaricação (art. 319 do CP) para a hipótese de retardo ou omissão de atos que devam praticar de ofício. ${ }^{228}$

No dizer de H. LOPES MeIRElles: “O poder tem para o agente público o significado de dever para com a comunidade e para com os indivíduos, no sentido de que quem o detém está sempre na obrigação de exercitá-lo". ${ }^{229}$

A Administração Pública, para a consecução de suas finalidades, estabelece deveres que deverão ser observados por seus agentes, bem como lhes veda determinadas condutas incompatíveis com a dignidade ou o bom andamento de seus serviços. $\mathrm{O}$ descumprimento desses deveres ou a prática dessas condutas vedadas acarretam para o agente público a responsabilidade administrativa.

A responsabilidade administrativa, em sentido amplo, compreende aquela a que está sujeito o agente público por qualquer ato no exercício de suas atribuições legais, inclusive aqueles sujeitos à legislação penal e à responsabilidade civil. Já em sentido estrito, é a obrigação de responder perante a Administração pela prática de ato ilícito que infrinja normas internas da Administração, regras de conduta relacionadas à função

\footnotetext{
${ }^{227}$ S. TOMÁs DE AQUINO, Suma teológica cit.,v. VI, p. 177.

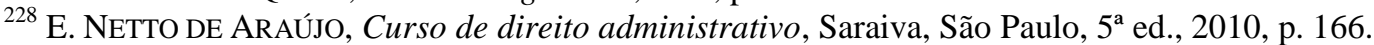

${ }^{229}$ H. LOPES MEIRELLES, Direito administrativo brasileiro cit., p. 107.
} 
pública. Segundo E. NETTO DE ARAÚJO, a responsabilidade administrativa em sentido estrito se desdobra em funcional e disciplinar. Para esse autor, somente aquelas infrações concernentes à relação hierárquica entre superior e subordinado são consideradas disciplinares. Os demais ilícitos administrativos, isto é, aqueles que não dizem respeito à relação entre superior e subordinado, como, p. ex., a violação dos deveres de "ser assíduo e pontual ao serviço" e de "tratar com urbanidade", seriam infrações funcionais ${ }^{230}$.

Muito embora a posição desse autor, conforme a linguagem corrente na doutrina, em especial M. CAETANO ${ }^{231}$, H. LOPES MEIRELles ${ }^{232}$, as infrações disciplinares e as funcionais serão aqui tratadas como sinônimas.

O serviço público possui uma organização hierárquica, isto é, seus servidores se dividem em superiores e subalternos; entretanto, como bem notou M. CAETANO, somente nos extremos da escala hierárquica essa classificação é nítida: entre a autoridade detentora de plenos poderes de direção - que pode ser um agente ou um colegiado - e o servidor a quem só correspondem deveres de obediência há diversos graus hierárquicos, cujos titulares terão ao mesmo tempo dever de obediência em relação aos superiores e poder de direção em relação aos subordinados ${ }^{233}$.

O poder hierárquico está intimamente ligado ao poder disciplinar, na medida em que, no dizer de T. BRANDÃo CAVALCANTI, "só quem está sujeito à subordinação hierárquica pode sofrer o efeito do poder disciplinar"; ou seja, só o superior hierárquico pode aplicar uma pena disciplinar ${ }^{234}$.

3.2 OS CONTORNOS DO PODER-DEVER DE PUNIR INFRAÇÕES DISCIPLINARES NA LEGISLAÇÃO VIGENTE

As infrações disciplinares dos juízes atualmente estão previstas no Código Judiciário do Estado de São Paulo, na Lei Orgânica da Magistratura Nacional e no Código de Ética elaborado pelo Conselho Nacional de Justiça.

\footnotetext{
${ }^{230}$ E. NetTo De ARAúJo, Curso de direito administrativo cit., p. 910-1.

${ }^{231} \mathrm{O}$ qual, inspirado em DuGUIT, divide as faltas disciplinares entre as que violam o estatuto positivo e as que violam o estatuto negativo. As primeiras, dizem respeito ao descumprimento de deveres profissionais; as segundas, as relacionadas à vida privada (M. CAETANO, Do poder disciplinar cit., p. 59).

${ }^{232}$ H. LOPES MEIRELLES, Direito administrativo brasileiro cit., p. 126.

${ }^{233}$ M. CAETANO, Do poder disciplinar cit., p. 4.

${ }^{234}$ T. BRandẽo CaVAlCANTI, Direito e processo disciplinar, Fundação Getúlio Vargas, Rio, $2^{\mathrm{a}}$ ed., 1966, p. 26.
} 
De acordo com o Código Judiciário Paulista, em seu art. 190, são deveres dos juízes: residir na sede de sua comarca; comparecer, nos dias de atividade forense, ao Forum, e aí permanecer durante o expediente, salvo quando em cumprimento de diligência judicial; usar toga, durante o expediente, conforme o modelo aprovado pelo Tribunal de Justiça; permanecer na sede do território sob sua jurisdição, comunicando sempre seu afastamento ao Presidente do Tribunal de Justiça; tratar com urbanidade as partes, testemunhas, funcionários e auxiliares da Justiça, e atender, a qualquer momento, quando se trate de assunto urgente, aos que o procurarem; presidir pessoalmente às audiências e aos atos para os quais a lei exige a sua presença; exercer assídua fiscalização sobre os seus subordinados, especialmente no que se refere à cobrança de custas e emolumentos, embora não haja reclamação das partes; e não frequentar lugares onde a sua presença possa diminuir a confiança pública na justiça.

No art. 35 da Lei Orgânica da Magistratura Federal, os deveres são: cumprir e fazer cumprir, com independência, serenidade e exatidão, as disposições legais e atos de ofício; não exceder injustificadamente os prazos para sentenciar ou despachar; determinar as providências necessárias para que os atos processuais se realizem nos prazos legais; tratar com urbanidade as partes, membros do Ministério Público, advogados, testemunhas, funcionários e auxiliares da justiça, e atender aos que o procurarem quando se trate de providência que reclame e possibilite solução de urgência; residir na sede da comarca, salvo autorização do órgão disciplinar a que estiver subordinado; comparecer pontualmente à hora de iniciar-se o expediente ou sessão e não se ausentar injustificadamente antes de seu término; exercer assídua vigilância sobre seus subordinados, especialmente no que se refere à cobrança de custas e emolumentos, mesmo que não haja reclamação das partes; e manter conduta irrepreensível na vida pública e particular.

Segundo o Código de Ética da Magistratura, publicado pelo Conselho Nacional de Justiça, são deveres dos juízes a independência, imparcialidade; transparência; integridade pessoal e profissional; diligência e dedicação; cortesia; prudência; sigilo profissional; conhecimento e capacitação; dignidade, honra e decoro ${ }^{235}$.

Em diversas passagens das Ordenações Filipinas, a palavra "virtuoso" é apresentada como requisito para o exercício da judicatura, e o fim buscado por esse juiz virtuoso deveria ser o "bem" dos "vassalos e povo". Não parece que a mudança de vocabulário, nesse caso, seja irrelevante; que o Código de Ética da Magistratura apenas

${ }^{235}$ J. R. NALINI, Ética da magistratura, RT, São Paulo, 2010. 
tenha buscado uma linguagem mais atual para descrever idênticas realidades, separadas apenas por quatro séculos e tanto. A virtude é muito mais abrangente que a ética exposta nesse código, e o "bem do povo" (não cabe atualmente falar em vassalos), embora não a exclua, dificilmente se atingiria por um aparato judicial voltado para a produtividade e a celeridade.

$\mathrm{O}$ atual Regimento Interno do Tribunal de Justiça, em seu art. 13, II, “g”, dispõe que compete ao Órgão Especial "instaurar e decidir os processos disciplinares contra magistrado e o afastamento preventivo da jurisdição". Na alínea "o" do mesmo artigo e inciso, é prevista a competência desse órgão para "deliberar sobre (...) afastamento ou aposentadoria por invalidez de magistrado". Seu art. 16, XII, fixa a competência do Conselho Superior da Magistratura para "instaurar o procedimento de verificação de invalidez de magistrado". Seu art. 28, que trata da competência do Corregedor Geral da Justiça, estabelece, no inciso II, a de "receber e, se for o caso, processar as reclamações e instaurar sindicância contra juízes, oficiando como instrutor e relator até o arquivamento ou a instauração definitiva de processo administrativo"; no inciso IV, a de "supervisionar os relatórios mensais dos juízes de direito e, quando necessário, submetê-los à apreciação do Conselho Superior da Magistratura"; no inciso VI, a de "fiscalizar, em caráter geral e permanente, a atividade dos órgãos e serviços judiciários de primeira instância (...)"; além de diversos outros dispositivos relacionados à atividade correicional. E o art. 90 trata do procedimento de verificação de incapacidade de magistrado ${ }^{236}$.

Parece que o "procedimento de verificação de incapacidade de magistrado" mencionado no art. 90 do Regimento Interno do Tribunal de Justiça de São Paulo é o mesmo referido no art. 28 sob o nome de "procedimento de verificação de invalidez de magistrado". Sendo assim, foi abandonada a tradicional expressão "incapacidade física ou moral", de modo que o conceito atual de incapacidade é equivalente ao de invalidez. E não há mais instauração de processo em razão de incapacidade moral, e sim processo administrativo disciplinar.

O Regimento atualmente em vigor também deixou de apresentar o rol de faltas disciplinares, que constava ao menos desde o Regimento de 1947. Não obstante, tais faltas são previstas no Código Judiciário do Estado de São Paulo, na Lei Orgânica da Magistratura Nacional e no Código de Ética baixado pelo Conselho Nacional de Justiça.

\footnotetext{
${ }^{236}$ Compilação do Regimento aprovada pelo Órgão Especial do Tribunal de Justiça de São Paulo em 25 de setembro de 2013 e publicada no Diário da Justiça de 21 de outubro de 2013.
} 
As penas hoje aplicáveis a um juiz, de acordo com o art. 42 da Lei Orgânica da Magistratura, são a advertência, censura, remoção compulsória, aposentadoria compulsória com vencimentos proporcionais e demissão.

As duas últimas, que implicam na perda da função pública, são a aplicação do princípio: quod medicamenta non sanant, ferrum sanat. Se as penas corretivas são ineficazes, recorre-se a penas depurativas ${ }^{237}$.

Para M. CAETANO, a demissão "não é exemplo, prevenção, expiação de um crime, sacrifício propiciatório à indignação colectiva - mas medida administrativa de depuração interna, um esforço de ajustamento do serviço aos seus objetivos"238.

Os diversos órgãos encarregados de exercer o controle disciplinar paulista são a Corregedoria Geral da Justiça, a quem incumbe a investigação preliminar à abertura de processo administrativo disciplinar, o Conselho Superior da Magistratura, a quem compete, em atividade correicional, a convocação de magistrados, o Órgão Especial, competente para a instauração e o julgamento de processos disciplinares de magistrados, e o Conselho Nacional de Justiça.

\subsection{OS VALORES PERMANENTES PARA O EXERCÍCIO DA JUDICATURA}

As virtudes constituem um núcleo permanente de valores indissociáveis do exercício da judicatura. A persistência de textos e discursos laudatórios relativos a juízes em toda a história brasileira demonstra que, apesar de todas as vicissitudes, das Ordenações do Reino de Portugal até hoje, a cultura da sociedade sempre considerou a virtude o adorno adequado à imagem daquele que julga.

Porém, já o PE. M. BERNARDES, em 1698, advertia que "quando duas virtudes se não podem exercitar no mesmo tempo, deve preferir-se a mais nobre"239. E E. VOEGLIN, em 1964, nas suas célebres conferências sobre Hitler e os alemães, desenvolvendo a reflexão de Carl Amery sobre as consequências do eclipse de virtudes primárias por secundárias, apontou o quanto o culto a virtudes como pontualidade, limpeza, diligência, obediência à autoridade etc., por parte dos alemães, virtudes essas que caracterizavam o cidadão bem-comportado, direito, simpático, mas que não punham em relevo qualquer das

\footnotetext{
${ }^{237}$ T. BRANDÃo CAVALCANTI, Direito e processo disciplinar cit., p. 90.

${ }^{238}$ M. CAETANO, Do poder disciplinar cit., p. 94.

${ }^{239}$ M. BERNARDES, Armas da castidade, Lello \& Irmão, Porto, in v. II das Obras, p. 12.
} 
virtudes cristãs primárias ou das virtudes noéticas ${ }^{240}$, contribuiu para a estupidez que resultou no nacional-socialismo ${ }^{241}$.

Há uma hierarquia entre as virtudes. A subversão dessa hierarquia será sempre desastrosa.

As virtudes dos juízes e a necessidade de repreensão dos vícios que se lhe opunham foram definidas por multissecular tradição filosófica e religiosa e incorporadas, explícita ou implicitamente, à cultura jurídica brasileira.

Exemplo disso, no Brasil colonial, eram as consequências do "escândalo", e no Brasil imperial e na Primeira República, o reconhecimento da "incapacidade moral" do magistrado transgressor.

Todavia, do processo histórico resultante do esgarçamento do conceito de federação, fruto da centralização verificada a partir do governo de Getúlio Vargas e do regime militar, resultou a criação do Conselho Nacional de Justiça, que, de Brasília, atualmente propõe e impõe à magistratura novos modelos de comportamento, lastreados não em virtudes, mas em pseudo-valores.

Esse fato é gravíssimo para a independência funcional, predicamento da magistratura já reconhecido de modo incipiente em diversas passagens das Ordenações e consolidado pela doutrina dos séculos XIX e XX, inclusive pela atual Constituição Federal.

Um desses pseudo-valores é a produtividade. Não é novidade que no Brasil que os juízes tenham uma pesada carga de trabalho. Entre outubro de 1690 e junho de 1692, a Relação da Bahia, então único Tribunal do Brasil, composto por dez desembargadores, julgou 4035 processos $^{242}$. Considerados os dois meses de férias previstos pelo Regimento daquele tribunal, a média de processos julgados atinge quase 250 por mês.

Por meio da Emenda Constitucional n. ${ }^{\circ}$ 19, de 4 de junho de 1998, foi modificada a redação do art. 37 da Constituição Federal, para nele ser incluído o "princípio da eficiência".

\footnotetext{
240 'A noesis é uma 'intelecção' ou 'intuição' (especialmente 'intuição inteligível', que se distingue da dianóia [ver] ou 'discurso'). O que pertence à noesis ou possui noesis é algo noético. (...) O termo 'noética' pode ser usado para designar tudo o que se refere ao pensar, especialmente o pensar 'objetivo' e ao mesmo tempo 'inteligível'” (J. FerRater MORA, Dicionário de filosofia, T. III, Loyola, p. 2100).

${ }^{241}$ E. VoEGLIN, Hitler e os alemães, É Realizações, Rio, 2008, p. 138-42. Essas virtudes secundárias não implicam fins em si mesmas, só são positivas se aplicadas a determinados fins. Por exemplo, pode-se ser pontual ao chegar à missa ou ao porão da Gestapo; pode-se lavar as mãos após o trabalho na plantação de milho ou no crematório do campo de concentração; pode-se obedecer a uma autoridade que determine algo justo ou assassinatos em massa etc.

${ }_{242}^{2}$ S. B. SCHWARTZ, Burocracia e sociedade cit., p. 132.
} 
A partir daí, antes mesmo da criação do Conselho Nacional de Justiça, a doutrina já vinha aplicando ao exercício da Magistratura conceitos próprios de Administração de Empresas e Economia.

Em obra publicada em 1997, S. A. Beneti faz uso dessa linguagem. Para esse autor, existe uma "magistratura de massa" e uma "magistratura artesanal", sendo a primeira aquela que lida com "situações processuais repetitivas", com a qual não se pode "perder tempo", pois exige "produção em série". Para esse gênero de processos, eram propostos - era um tempo em que o uso dos recursos de informática eram ainda incipientes - despachos em carimbos, sentenças em impresso com espaços em branco para o preenchimento das particularidades do caso etc. O juiz é comparado a um "gerente de produção", para quem o "pessoal do cartório, as máquinas de que dispõe e os impressos" são "instrumentos" em uma "linha de produção", cujo "produto final" é a prestação jurisdicional. Para o juiz, como para o empresário, "tudo vale" para atingir maior produção: a disposição para o trabalho, a dedicação por longo horário, o bom-nome, a seriedade de comportamento no ramo de atividade e a imagem de organização oferecida a quem procura os serviços. Tudo é instrumento da jurisdição, tudo auxilia a terminar os processos, da mesma forma que, para o industrial ou o comerciante, tudo o que há na fábrica ou loja serve à atividade industrial ou comercial ${ }^{243}$.

No contexto da tentativa de alçar a produtividade à condição de "virtude" está a ideia de que o juiz se insere em uma linha de produção. Tal linguagem é absolutamente inadequada. Produtividade não é virtude. A laboriosidade, a dedicação, a imparcialidade, o estudo atento dos processos, a busca constante, enfim, de dar a cada um o que é seu, estão no cerne da virtude da justiça. Mas a produtividade, não.

A produtividade contenta-se com resultados quantitativos que podem ser a exata expressão do vício da injustiça.

Lamentavelmente, o culto à produtividade tornou-se paradigmático após a criação do Conselho Nacional de Justiça pela Emenda Constitucional n..$^{\circ} 45$, de 8 de dezembro de 2004.

No âmbito do Tribunal de Justiça de São Paulo, em atendimento às normas baixadas pelo órgão central para aumentar a produtividade, foi celebrado um convênio com a Fundação Getúlio Vargas, pelo qual diversas alterações na rotina dos trabalhos dos

${ }^{243}$ S. A. BENETI, Da conduta do juiz, Saraiva, São Paulo, 1997, p. 10-2.111 
servidores foram concebidas por profissionais de outras áreas, cursos foram ministrados aos cartorários, Normas de Serviço foram adaptadas etc.

Em cursos, foi ensinado aos serventuários da Justiça que as partes nos processos deveriam, doravante, ser consideradas "clientes da empresa". Numa dessas ocasiões, foi grande o constrangimento quando um escrevente, de modo bastante singelo, observou ao palestrante que era absolutamente inadequado aplicar essa terminologia ao réu de um processo criminal.

O principal problema dessa visão é a substituição do dever de laboriosidade, que todo juiz sempre teve ${ }^{244}$ para o dever de "produtividade". Quando o dever consiste não mais em "laborar", mas em "produzir", legitimam-se certos meios que, em determinadas circunstâncias, são moralmente questionáveis. Hoje, é comum ouvir-se de juízes que o importante é dar logo a sentença, certa ou errada, porque se estiver errada "o Tribunal corrige" - como se o fundamento da existência do duplo grau de jurisdição fosse confortar a consciência do juiz pressionado a "produzir" sentenças e decisões em grande quantidade. Nesse "vale tudo" se incluem os cada vez mais frequentes despachos e sentenças feitos por funcionários do cartório ou assistentes, os modelos de sentenças com fundamentação o mais genérica possível, para que possam ser utilizados no maior número de processos, a proliferação de Juizados Especiais e até de Juizados Itinerantes, as campanhas publicitárias promovendo "mutirões de conciliação", a cobrança cada vez mais crescente de relatórios de produtividade etc.

Porém, a efetiva incorporação desse ideário na rotina forense não trouxe, ao menos até o momento, qualquer melhora no conceito do Poder Judiciário perante a população. A imagem de que a Justiça é lenta - acusação já vulgarizada nas Cortes medievais, e mesmo antes, ao tempo de Carlos Magno, o qual determinou que se a sentença demorasse, o litigante podia se hospedar na casa do juiz e viver à custa dele até que o processo tivesse seguimento ${ }^{245}$ - persiste. Sabe-se que atualmente ${ }^{246}$ até mesmo cidadãos comuns, sem qualquer antecedente criminal, preferem se valer da arbitragem de pessoas vinculadas ao crime organizado, do que buscar no Poder Judiciário a solução de seus conflitos. Nunca estivemos mais longe do acatamento e respeito de que tradicionalmente a Justiça gozou perante a sociedade.

\footnotetext{
${ }^{244}$ Confira-se, por exemplo, as Ordenações Filipinas, Livro I, título. I, § 45.

${ }^{245}$ M. GUIMARÃES, O juiz e a função jurisdicional cit., p. 230

${ }^{246}$ J. R. NALINI, A rebelião da toga cit., p. 212.
} 
Outro pseudo-valor que vem sendo imposto à magistratura é o ativismo judicial.

Baseados em uma equivocada percepção de que a formação jurídica no Brasil é tradicionalmente positivista, propõe-se, com o exemplo partido da mais alta Corte, que os juízes se arroguem a funções legislativas. Exemplo disso foram as decisões judiciais em que se autorizou o aborto nos casos de anencefalia (embora a palavra tenha sido substituída por algum eufemismo) e o "casamento" entre pessoas do mesmo sexo, em ambos os casos contra legem.

É certo que o Poder Legislativo vive uma crise gravíssima de representatividade, e que o Poder Judiciário, a despeito de seus vários problemas, ainda goza de algum prestígio. Mas isso não o legitima a subverter o princípio da separação dos poderes para legislar.

Outra situação preocupante é aquela em que o Conselho Nacional de Justiça e as Corregedorias Gerais de Justiça se atribuem o papel de orientar os juízes.

À primeira vista, a valorização da orientação em detrimento do exercício da função punitiva parece simpática. Entretanto, a punição tem por pressuposto o nulla poena sine lege, já a orientação fica ao sabor das idiossincrasias do titular do poder correicional. Há o risco de a orientação cercear a independência funcional, se essa orientação for dada por alguém imbuído de viés ideológico, como, p. ex., o da febre da produtividade e o “ativismo". É patente o risco de a função orientadora se confundir com o poder disciplinar, o qual, em se tratando de magistrados, agentes políticos que são, tem limitações muito precisas, dados os princípios da livre convicção e da independência funcional. Há perigo de a Magistratura se tornar refém de doutrinação por parte dos detentores do poder político. Daí a necessidade de delimitação claríssima entre poder disciplinar e poder gerencial.

É de clareza manifesta que os exemplos arrastam, que um bom juiz naturalmente servirá de inspiração para os novatos, isso é desejável e salutar. O problema surge quando isso não se dá de modo natural, mas enquanto mecanismo de coerção.

J. R. NALINI, em interessante estudo, partindo do pressuposto de que os juízes brasileiros estão atualmente em "crise de identidade", apontou diversos aspectos da atual configuração do Poder Judiciário como causas para essa crise. Dentre suas críticas, destacam-se: 1. Pluralidade de tribunais, mais de cem no Brasil, os quais, até a criação do Conselho Nacional de Justiça, não tinham um órgão de planejamento ou controlador; e pluralidade de instâncias. 2. Assunção dos órgãos de comando do Poder Judiciário por magistrados pouco afeiçoados às modernas técnicas de administração, apesar de bons 
juízes; 3. Formalismo que leva à extinção de processos sem julgamento de mérito; e 4. Formação jurídica dos profissionais do Direito ultrapassada, já anacrônica quando importada de Coimbra, que resulta em juízes positivistas, apegados à tradição ${ }^{247}$.

Todavia, não parece que tais aspectos tenham relevância na crise constatada.

A existência de mais de uma centena de tribunais no atualmente no Brasil (Tribunais de Justiça, Tribunais Regionais Federais, Tribunais Regionais do Trabalho, Tribunais da Justiça Militar, Tribunais Regionais Eleitorais, Superior Tribunal de Justiça, Tribunal Superior do Trabalho, Tribunal Superior Militar, Tribunal Superior Eleitoral e Supremo Tribunal Federal) foi opção da Assembleia Nacional Constituinte consentânea com a história brasileira. A autonomia de cada um desses tribunais e a ausência de hierarquia, coordenação ou planejamento entre eles até a criação do Conselho Nacional de Justiça não era em si um verdadeiro problema. A suposta necessidade remediada pela criação de um órgão de controle, tem por pressuposto a controvertida ideia de que os Tribunais podem ser governados de acordo com as regras de administração de empresas.

A pluralidade de instâncias, apontada como óbice à efetivação da Justiça, decorre da tendência centralizadora examinada ao longo deste trabalho. A existência de um direito de recorrer responde a exigências da natureza humana; o homem naturalmente tende a manifestar seu inconformismo contra uma decisão que lhe seja desfavorável e isso em si não é reprovável. No Império e na Primeira República, quando a autonomia das Províncias e dos Estados era mais prestigiada, a regra proclamada em nível constitucional era os Tribunais da Relação ou de Justiça serem a última instância. Foi o modelo centralizador adotado depois de 1930 que aumentou as hipóteses de recurso à Corte Constitucional e aos Tribunais Superiores, fazendo com que qualquer matéria em tese mereça ser examinada por um tribunal que esteja hierarquicamente acima dos tribunais locais e que o número de instâncias chegue a quatro.

Quanto à crítica à ocupação dos postos de comando dos tribunais por magistrados que, apesar de bons juízes, não tem os necessários conhecimentos das modernas técnicas de Administração, verifica-se que novamente se baseia no discutível pressuposto de que "bom juiz não se confunde com bom administrador", que, em suma, administrar o Poder Judiciário é equiparável, guardadas as devidas proporções, a administrar uma empresa.

Porém, observa-se que para o Poder Executivo, que administra a coisa pública em escala muito maior que o Poder Judiciário, também não se exige, nem jamais se pensou em

${ }^{247}$ J. R. NALINI, A rebelião da toga, Millenium, Campinas, 2008, 2a ed., p. 1 - 30. 
exigir (salvo, talvez, uma iniciativa isolada de uma "Escola de Governo"), formação semelhante. E o povo brasileiro, chamado periodicamente às urnas para escolher os ocupantes dos cargos do Poder Executivo, jamais levou em consideração semelhante requisito. Mesmo aqueles candidatos que eventualmente tenham esse tipo de formação não costumam invocá-la como vantagem em relação a adversários que não a têm. Igualmente, para o Poder Legislativo, a quem incumbe precipuamente a elaboração de leis, o povo não leva em conta a formação jurídica de seus membros. Dos três poderes, o único do qual se exige formação específica para seus membros é o Poder Judiciário, e essa formação específica é em Direito, não em Administração de Empresas. Portanto, acrescentar à necessária formação em Direito a exigência de outra formação, ainda que em nível que não seja o universitário, não parece razoável.

O que se espere de um bom juiz é que ele julgue bem, não que ele "administre" sua Vara como se fosse uma pequena empresa. De um juiz que seja escolhido para ser Diretor do Fórum, espera-se que ele cuide do Fórum com o mesmo zelo que um bonus pater familiae, nada mais. De um desembargador que ocupe a Presidência de seu Tribunal, idem. E assim por diante... A prudência, a temperança, enfim, as virtudes que deveriam exornar os ocupantes da Magistratura farão o restante.

É claro que sempre haverá quem se sobressaia por uma ou outra habilidade excepcional, e isso sempre poderá ser levado em conta por aqueles a quem incumbe a escolha. Mas daí a erigir uma formação específica como requisito para ocupar determinado cargo que acumule funções administrativas, ou tornar essa formação desejável, com base apenas em na discutível ideia de que a administração de uma empresa e a de um Tribunal possam ter algumas semelhanças, há enorme diferença.

A crítica ao formalismo propõe um falso dilema entre forma e substância. As formalidades legais são limites precisos ao arbítrio judicial. Ninguém seria favorável a um formalismo estéril, à observância de formalidades sem sentido. Mas, é lícito perguntar, existem tais formalidades na nossa legislação? E, se existem, por que existem? Quem as inventou? Por que o Poder Legislativo não as ab-roga?

Se procurarmos em séculos passados, ou em culturas jurídicas de origem distante da nossa, certamente encontraremos formalidades que, seguidas entre nós, passariam por “formalismo estéril". Porém, entre nós, bem raros seriam os exemplos de formalidades que, tendo se tornado inócuas em algum momento histórico, não foram logo expurgadas da legislação. Talvez a audiência de instrução e julgamento obrigatória nos processos de 
desapropriação (ar. 24 da Lei n. ${ }^{\circ}$ 3.365/1941), que poderia ser substituída pela manifestação escrita das partes sobre o laudo pericial e daí passar-se imediatamente à sentença. E mais uma ou outra hipótese.

O problema de uma crítica genérica ao formalismo, sem que sejam apontadas claramente quais as formalidades que devam ser rejeitadas, é que abre as portas a todo o tipo de arbitrariedade. O juiz faz o que quer, como quer, porque quer, e a quem ousar lembrá-lo de que a lei estabelece determinada forma para aquele ato, ele responde que "isso é formalismo", como se a aposição desse rótulo fosse capaz de legitimar qualquer abuso.

A contrapartida à garantia da mais ampla liberdade de convencimento deve ser o rigoroso cumprimento das formalidades que, forjadas pela sabedoria e experiência do legislador, impõem limites à tirania judicial.

É realmente injusto que quem perdeu o prazo de um recurso, ainda que estivesse amparado pelo Direito, seja atingido pela preclusão ou pela coisa julgada? Se a resposta for sim, a consequência seria a necessidade de relativização de todos os prazos processuais. Mas quem seria temerário a ponto de sustentar que a relativização de todos os prazos processuais tornaria a Justiça mais justa? Estaria o povo brasileiro, que é o destinatário último da jurisdição, interessado em abrir mão da segurança jurídica nesse caso? Parece que não.

A crítica à proliferação indiscriminada de Faculdades de Direito nos últimos anos, que provocou uma grave queda na qualidade dos profissionais do Direito, é a mais relevante e em muitos aspectos deve ser acolhida. De fato, o generalizado desconhecimento de nossa legislação e da ciência do Direito é causa suficiente para uma crise sem precedentes no Poder Judiciário. Porém, não consta que o estilo importado de Coimbra tenha alguma relação com a crise atual. Fixando-se, quase que aleatoriamente, o ponto inicial da queda de qualidade do ensino jurídico no início da década de 1990, teríamos um hiato de cento e sessenta e três anos entre a fundação das duas primeiras Faculdades de Direito de nosso país e esse ponto inicial. Ora, o Brasil pode se orgulhar de uma plêiade de juristas do mais alto quilate formados ao longo desse período, como um Barão de Ramalho, um Marquês de São Vicente, um Teixeira de Freitas, um Clóvis Bevilacqua, um Ruy Barbosa, um Pontes de Miranda, para falar apenas nos já falecidos e ainda hoje muito estudados. E a experiência nos mostra, e para aqueles que não tiveram essa experiência basta que folheiem os autos de qualquer processo anterior a 1990 
escolhido ao acaso, que até essa época mesmo os profissionais do Direito menos conhecidos demonstravam em qualquer manifestação uma formação mais sólida do que a média dos que se formaram posteriormente.

E também não se pode negar que, mesmo após o início da derrocada do ensino jurídico na década de 1990, continuaram a existir centros de excelência.

Outro ponto é que o positivismo jurídico foi fenômeno bem posterior à fundação das primeiras Faculdades de Direito brasileiras; e que o ensino jurídico no Brasil, durante muitas décadas, contou com uma cátedra de Direito Natural.

É grave o risco de se adaptar a norma luterana Ecclesia sempre reformanda para o Poder Judiciário, propondo-se uma Iustitia semper reformanda. No sistema de "freios e contrapesos" adotada pela maior parte das Constituições atualmente em vigor, a magistratura funciona como elemento conservador, enquanto as iniciativas de reforma cabem aos demais poderes do Estado. Os modelos ora impostos aos juízes apontam para uma inversão desses papéis.

$\mathrm{Na}$ imposição desses modelos, assume preponderância a abusiva exigência de incontáveis planilhas e relatórios como forma de controle da atividade jurisdicional. Pelo menos desde a fundação da Relação da Bahia, no século XVII, eram enviados relatórios periódicos à Coroa, o que é bastante razoável. Contudo, a multiplicação de requisições de informações hoje existente, que subtrai tempo considerável de juízes e serventuários, tem por escopo a realização de avaliações de produtividade e verificação do cumprimento de metas para muitos inviáveis.

Sobre os mecanismos de controle, é caso de dizer que, se o juiz tiver a qualificação técnica e a idoneidade que se pressupõem para a sua aprovação em concurso, serão inócuos desnecessários ou nocivos.

A manipulação de estatísticas pelo Conselho Nacional de Justiça (tantos milhares de acordos em uma semana de conciliação, tantos processos julgados de acordo com a meta $\mathrm{x}$ ou $\mathrm{y}$, tudo isso divulgado ad nauseam à população, sob o suposto abrigo do princípio constitucional da transparência) não passa de publicidade. E esse tipo de publicidade - apenas justificável se se admitir a falácia da equiparação entre a administração de uma empresa privada e a administração da justiça -é moralmente inaceitável.

Qualquer tentativa de recuperação da credibilidade do Poder Judiciário que passe por gastos publicitários é ilícita. A respeitabilidade da instituição só pode ser de fato 
recuperada na medida em que cada jurisdicionado - satisfeito ou não com a decisão tomada - puder acreditar que essa decisão foi tomada com seriedade, por um juiz íntegro. Somente na relação juiz/jurisdicionado é que este último tem condições de avaliar se o primeiro é honesto, preocupado em dar a cada um o que lhe pertence. Tudo o mais é ingressar na lógica da política, no sentido mais rasteiro que essa palavra pode assumir.

No atual contexto, é absolutamente necessário que a objeção da consciência seja reconhecida como legítimo meio de defesa em processo disciplinar contra magistrado. Aquele que, premido pelo senso do dever de examinar atentamente os autos dos processos que lhe foram conclusos, resiste à pressão para cumprir metas formuladas para ilustrar campanhas publicitárias que nem de longe estão preocupadas com a qualidade dos julgamentos em massa, sem esse meio de defesa estaria condenado por ser virtuoso, por cumprir com exatidão os deveres de seu cargo. 


\section{CONCLUSÕES}

No período colonial, a concepção de que o rei, órgão máximo da administração da justiça, era subordinado a Deus; e, portanto, não era absolutamente livre para criar o direito, mas estava limitado pelo direito natural e pela lex aeterna, permitia que a disciplina da magistratura fosse objeto da teologia moral, da qual receberam influência diversos dispositivos legais. E mesmo quando não positivados, os desenvolvimentos dos moralistas continuavam a ser o critério último para avaliação da conduta dos juízes. Isso porque não havia a pretensão de tipificar todas as condutas indesejáveis, e aquelas que chegavam a ser tipificadas eram exemplificativas de valores subjacentes.

A partir da mentalidade que alimentou a Revolução Francesa e seus movimentos subsequentes, a doutrina da disciplina da magistratura passou a ser examinada sob o prisma das garantias constitucionais à imparcialidade dos julgamentos. A oscilação entre a flexibilização dessas garantias, que caracterizou todos os regimes autoritários, e a quase intangibilidade delas, nos momentos de maior apreço pela democracia, revelam o papel do Poder Judiciário no funcionamento dos diversos regimes políticos. Quando o Estado se arroga ao papel de criar o direito ex nihilo, a disciplina da magistratura pode se se vincular a fins políticos a ponto de a "incompatibilidade com o regime" e situações congêneres se transformarem em infrações.

É absolutamente legítimo e necessário que o Poder Judiciário disponha de um ou mais órgãos incumbidos do exercício do poder disciplinar sobre os juízes. Porém, para a salvaguarda da independência funcional, as hipóteses autorizadoras do exercício desse poder não podem ser concebidas por esses órgãos disciplinares, nem pelo poder executivo. Quanto ao poder legislativo, ao prever tais hipóteses, deve se fundamentar naquelas consagradas pela nossa cultura jurídica, tal como se desenvolveram historicamente até os nossos dias.

É constante no Brasil a tensão entre a tendência à autonomia das Capitanias, Províncias e Estados e o fortalecimento do Poder Central, seja ele a Metrópole, a Coroa ou a União. Por contingências históricas, dos primórdios da Capitania de São Vicente à Revolução Constitucionalista de 1932 os paulistas estiveram à frente das pretensões por maior autonomia. E a disputa pela titularidade do exercício do poder disciplinar em relação aos juízes teve e tem significativa importância nesse conflito. A presença de Ouvidores, 
Ouvidores Gerais e das Relações, no período colonial, foi indicativa de uma tendência centralizadora, a qual foi mantida nos primeiros anos de vigência da Constituição Imperial. Porém, a partir do Ato Adicional de 1834, que concedeu maior autonomia às Províncias, inclusive transferindo para elas o poder de punir juízes de primeira instância, teve início o processo de descentralização, cujo ápice será o período de vigência da Constituição de 1891. Com o golpe de Getúlio Vargas, em 1930, a tendência centralizadora novamente se impôs, não sem retrocessos, como em 1934 e em 1946, mas fortalecendo-se depois deles, como em 1937, 1967 e 1969. Em cada um desses momentos, a tendência vitoriosa assumiu o controle do poder disciplinar dos juízes. Nesse contexto, a criação do Conselho Nacional de Justiça, em 2005, representou um triunfo do ideário centralizador.

O juiz deve ser um homem virtuoso; essa ideia é uma constante na história do Poder Judiciário. Aliás, parece que essa associação entre judicatura e virtude - chame-se por outro nome, reputação ilibada - é um dos elementos que, ao lado de outros como o notório saber jurídico, legitimam o poder do juiz, que não lhe é dado pelas urnas.

Nosso trabalho procurou demonstrar que as diversas legislações, sob os mais diversos nomes - capacidade moral, reputação ilibada etc.--, jamais prescindiram da virtude, e sempre se mostraram aparelhadas para punir o seu oposto, isto é, o vício nos juízes. Porém, a par disso, a partir da terceira década do século passado, foi tendência constante dos regimes autoritários a tentativa de incluir entre os motivos para a punição dos juízes a não compatibilidade com os valores do grupo que se assenhoreou do poder. Foi assim com Getúlio Vargas, foi assim com o regime militar, e continuou assim com a ascensão da esquerda ao governo do Brasil, a qual criou um órgão centralizado de controle do judiciário.

Não está no propósito deste trabalho fazer uma crítica à existência do Conselho Nacional de Justiça. Admitindo-se que algumas Corregedorias da Justiça não cumpriam bem o seu papel, a existência desse órgão estaria, em princípio, justificada. Todavia, na medida em que esse órgão centralizador, que de fato quebrou uma tradição federativa mais que centenária, e cujo processo de escolha de seus membros mostra claramente a intenção nesse sentido, se propõe a estabelecer parâmetros de comportamento para os juízes, claro está o risco à independência funcional.

Não é legítimo que a "improdutividade", que não é vício, seja utilizada para punir algum juiz por infração disciplinar. A desídia, sim, é vício e sempre foi motivo para punição. Também não é legítima a punição de um juiz por incompatibilidade com qualquer 
outro "valor" de algum grupo político que tenha assumido ou venha a assumir o poder político no Brasil.

A "produtividade" é valor apenas para o fordismo e outras correntes políticoideológicas que nele se inspiraram. Com a alternância de grupos no poder que é praticamente uma exigência histórica, algum dia a "produtividade" não fará mais sentido e outros modismos poderão the ocuparão o lugar. "Metas de produtividade", "criatividade," "inovação", "recusa ao formalismo" etc. são os nomes atuais da compatibilidade com o regime dos partidos políticos que hoje governam o país. Punir juízes que não se enquadrem no perfil desenhado pelos ideólogos que atualmente detém o poder é repetir erros do passado.

As orientações, metas, normas e outras atualmente expedidas pelo Conselho Nacional de Justiça, quando desvinculadas da moral ou da ética, nada mais são do que mal disfarçada tentativa de dar à magistratura um perfil alinhado a determinada política. Nesse conjunto se insere o culto à produtividade, o ativismo etc.

A percepção de que a independência funcional, ao contrário, é um valor permanente para o exercício da judicatura exige que tudo aquilo que lhe represente uma ameaça seja objeto de preocupação.

Que os juízes viciosos, tanto no exercício de suas funções quanto na vida pessoal, sejam punidos, é uma necessidade inquestionável. Porém, que os juízes possam ser punidos por inconveniência com qualquer regime político é inadmissível.

A sociedade brasileira atravessa uma crise profunda. Este trabalho não tem a pretensão de apontar remédios para essa crise, contenta-se em alertar para que, a pretexto de remediá-la, não se cometam erros que a agravem ainda mais. 


\begin{abstract}
Following general belief that its first colonizers were of noble descent, the proud Estate of São Paulo developed by cherishing nobility, family, religion, bravery and autonomy, values that mirrored the virtues required from its magistrates. Since the Colonial period, with its complex structure of juxtaposing jurisdictions, judges were required to be impartial, honest and devoted to work. Correctional Power aimed at punishing corruption and public misbehavior. In spite of the structural changes ensuing the 1822 Independence of Brazil and the 1889 Proclamation of Republic, these traditional values persisted, so much so that the main Courthouse of São Paulo, its Tribunal of Justice, still calls itself "Justiça Bandeirante". The last decades, however, have brought substantial change: judges are now expected to be proactive and to adopt management techniques to increase the number of cases solved. In an era where productivity supersedes the traditional values, there's a risk that the Correctional Power, sometimes misrepresented as "guidance", might attempt to coerce the judicial independence for the sake of the political ideologies of the moment.
\end{abstract}




\section{RESUMO}

De acordo com a crença de que seus primeiros colonizadores tinham ascendência nobre, o orgulhoso Estado de São Paulo se desenvolveu cultivando valores como nobreza, família, religião, bravura e autonomia, os quais se refletiram nas virtudes exigidas de seus magistrados. Desde o período Colonial, com sua complexa estrutura de jurisdições justapostas, exigia-se dos juízes que fossem imparciais, honestos e devotados ao trabalho. O Poder Correicional se ocupava de punir corrupção e mau comportamento em público. Apesar das mudanças estruturais que se seguiram à Independência em 1822 e à Proclamação da República em 1890, esses valores tradicionais persistiram, tanto assim que a principal Corte de São Paulo, seu Tribunal de Justiça, ainda se refere a si própria como "Justiça Bandeirante". As últimas décadas, no entanto, trouxeram mudança substancial: espera-se agora dos juízes que sejam proativos e que empreguem técnicas de administração para aumentar o número dos processos julgados. Numa época em que a produtividade triunfa sobre as virtudes tradicionais, há risco de que o Poder Correicional, algumas vezes travestido de "orientação", tente coagir a independência judicial para servir às ideologias políticas do momento. 


\section{BIBLIOGRAFIA}

ANDRADE E SILVA, José Justino de; Collecção chronologica da legislação portugueza compilada e anotada, 11 vols, Imprensa de J. J. A. Silva (1603 - 1612, 1613 1619 e 1620 - 1627) - Imprensa de F. X. de Souza (1627 - 1633, 1634 - 1640, 1640 1647, 1648 - 1656, 1657 - 1674, 1675 - 1683 e suplemento à segunda série 1641 - 1683) e Imprensa Nacional (1684 - 1700 e 1701), Lisboa, 1854 - 1859 (11º vol. s. d.), disponível em www.iuslusitaniae.fcsh.unl.pt.

AZEVEDO, Luiz Carlos de. Introdução à história do direito, São Paulo, RT, 2005. , O direito de ser citado, FIEO - Resenha Universitária, São Paulo, 1980.

AZEVEDO MARQUES, Manuel Eufrásio de; Apontamentos históricos, geográficos, biográficos, estatísticos e noticiosos da Província de São Paulo seguidos da cronologia dos acontecimentos mais notáveis desde a fundação da Capitania de São Vicente até o ano de 1876, Tomo I, Livraria Itatiaia e Editora da Universidade de São Paulo, Belo Horizonte, 1980.

BARBALHO DE UCHÔA CAVALCANTI, João; Constituição federal brasileira (1891) comentada, Companhia Litho-Typografia, Rio, 1902, edição fac-similar do Senado Federal, 2002.

BARBAS HOMEM, Antonio Pedro; Judex perfectus: função jurisdicional e estatuto judicial em Portugal 1640 - 1820, Almedina, Coimbra, 2003.

BARRETO DO AMARAL, Antonio; Dicionário de história de São Paulo, Imprensa Oficial, São Paulo, 2006.

BASTOS VON BRUCK LACERDA, Paulo Francisco, Fundamentos do processo administrativo disciplinar, dissertação de mestrado, FDUSP, São Paulo, 2004.

BENETI, Sidnei Agostinho; Da conduta do juiz, Saraiva, São Paulo, 1997.

BERNARDES, Manoel; Armas da castidade, Lello \& Irmão, Porto, in v. II das Obras.

BLUTEAU, Raphael; Vocabulario portuguez \& latino, aulico, anatomico, architetonico..., Coimbra, Collegio das Artes da Companhia de Jesus, 1712 - 1728, 8 v., disponível em www.brasiliana.usp.br. 
BRANDÃO CAVALCANTI, Themístocles; Direito e processo disciplinar, Fundação Getúlio Vargas, Rio, 2ª ed., 1966.

BROTERO, Frederico de Barros; Tribunal de Relação e Tribunal de Justiça de São Paulo sob o ponto de vista genealógico: aditamentos a Silva Leme, São Paulo, 1944.

CAETANO, Marcelo; Do poder disciplinar no direito administrativo português, Imprensa da Universidade, Coimbra, 1932.

CALDAS AULETE, F. J.; Dicionário contemporâneo da língua portuguesa, v. II, Parceria Antonio Maria Pereira, Lisboa, $3^{\mathrm{a}}$ ed., 1948.

CARVALHO, José Murilo de (coordenador); A construção nacional: 1830 - 1889, vol. 2, Objetiva, Rio, 2012.

; PEREIRA CAMPOS, Adriana (organizadores); Perspectivas da cidadania no Brasil império, Civilização Brasileira, Rio, 2011.

CASTRO NUNES; As constituições estaduaes do Brasil commentadas entre si e com a constituição federal, T. I, Livraria Editora Leire Ribeiro, 1922.

CORRÊA DE SÁ E BENEVIDES, José Maria; Analyse da Constituição política do Império do Brazil, Typographia King, São Paulo, 1890.

COSTA MANSO, Manoel da; O processo na segunda instância e suas aplicações à primeira, $1^{\circ}$ v. Livraria Acadêmica - Saraiva \& Comp. Editores, São Paulo, 1923.

CRUZ E TUCCI, José Rogério; AZEVEDO, Luiz Carlos de; Lições de processo civil canônico, RT, São Paulo, 2001.

; Lições de história do processo civil romano, RT, São Paulo, 1ª ed., 2001.

CUNHA, Paulo Ferreira da; SILVA, Joana Aguiar e; SOARES, Antonio Lemos; História do direito: do direito romano à constituição europeia, Almedina, Coimbra, 2005.

DE PLACIDO E SILVA, Vocabulário jurídico, Forense, Rio, 2009, $28^{\text {a }}$ ed.

ESCRAGNOLlE TAUNAY, Afonso de; São Paulo nos primeiros anos - São Paulo no século XVI, Paz e Terra, São Paulo, 2003.

FLEIUSS, Max; História administrativa do Brasil, Imprensa Nacional, Rio, 1923.

GUIMARÃES, Mário; O juiz e a função jurisdicional, Forense, Rio, $1^{\mathrm{a}}$ ed., 1958.

LEITE, Aureliano; História da civilização paulista, Saraiva, 1954.

LIMA, Hermes (org.), Estudos sobre a Constituição brasileira, Fundação Getúlio Vargas, Rio, 1954.

MACEDO DE CAMPOS, Antônio (anotador e atualizador); Regimento interno do Tribunal de Justiça do Estado de São Paulo, Jalovi, Bauru, 1ª ed., 1978. 
MADRE DE DEUS, Frei Gaspar da; Memórias para a história da Capitania de São Vicente, USP - Itatiaia, São Paulo - Belo Horizonte, 1975.

MAIA LUZ, Egberto; Direito administrativo disciplinar, RT, São Paulo, $3^{\mathrm{a}}$ ed., 1994.

MALHEIROS, Lauro; SÁ, Moacyr de; Regimentos internos do Tribunal de Justiça e do Tribunal de Alçada do Estado de São Paulo, RT, São Paulo.

MARTINS, Antonio Egydio; São Paulo antigo, Paz e Terra, São Paulo, 2003.

MARTINS FERREIRA, Waldemar; História do direito constitucional brasileiro, Max Limonad, São Paulo, 1954.

MESQUITA DE OLIVEIRA, Roque Antonio (realização), 60 anos: o ideal que nos fez Apamagis, Rosa de Ouro Comunicação, São Paulo, 1ª ed., 2013.

MOURA BITTENCOURT, Edgard de; $O$ juiz, Editora Jurídica e Universitária Ltda., Rio e São Paulo, 1966.

MÜLLER, Daniel Pedro; Ensaio d'um quadro estatístico da Província de São Paulo ordenado pelas leis provinciais de 11 de abril de 1836 e 10 de março de 1837, Governo do Estado de São Paulo, São Paulo, $3^{\text {a }}$ ed. facsimilada, 1978.

NALINI, José Renato; Ética da magistratura, RT, São Paulo, 2009. ; A rebelião da toga, Millenium, Campinas, $2^{\mathrm{a}}$ ed., 2008.

NORONHA, Ibsen José Casas; Aspectos do direito no Brasil quinhentista: consonâncias do espiritual e do temporal, Almedina, Coimbra, 2005.

POVEDA VELASCO, Ignacio Maria; Os esponsais no direito luso-brasileiro, Quartier Latin, São Paulo, 2007.

RODRIGUES, José Carlos; Constituição política do Império do Brasil, Eduardo \& Henrique Laemmert, 1863.

SALVADOR, Frei Vicente do; História do Brasil 1500 - 1627, Itatiaia - USP, Belo Horizonte - São Paulo, 1982.

SÃO VICENTE, Marques de (José Antônio Pimenta Bueno); Direito público brasileiro e análise da Constituição do Império, Editora 34, São Paulo, 2002.

SAINT HILAIRE, Auguste de; Viagem à província de São Paulo, Livraria Itatiaia e Editora da Universidade de São Paulo, Belo Horizonte, 1976.

SCHWARTZ, Stuart B., Burocracia e sociedade no Brasil colonial: o tribunal superior da Bahia e seus desembargadores, Companhia das Letras, São Paulo, $2^{\mathrm{a}}$ ed., 2011. 
SILVA LEME, Luiz Gonzaga da; Genealogia paulistana, Duprat e Cia., São Paulo, 1904.

SILVEIRA MARCHI, Eduardo Cesar; Guia de metodologia jurídica, Saraiva, São Paulo, $2^{\text {a }}$ ed., 2009.

TAQUES DE ALMEIDA PAES LEME, Pedro; Nobiliarchia paulistana historica e

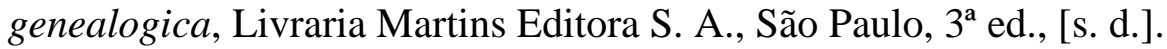

TOMÁS DE AQUINO, Santo; Suma Teológica, Loyola, São Paulo, 2005.

TOLEDO, Roberto Pompeu de; A capital da solidão: uma história de São Paulo das origens a 1900, Objetiva, Rio, 2012.

TORRES, Flávio; Tribunal de Justiça de São Paulo: páginas de sua história centenária, São Paulo, 1979.

VICENTE DE LERINS, São; Comonitório - regras para conhecer a fé verdadeira, Permanência, Niterói, 2009, trad. do espanhol de Fabiano Lyrio Silva.

ZALUAR, Augusto Emílio; Peregrinação pela província de São Paulo: 1860 1861, Edições Cultura, São Paulo, 2a ed., 1945. 